$\mathbb{1}$ Nordregio

\title{
Developing brownfields via public-private-people partnerships
}

Lessons learned from Baltic Urban Lab

Sandra Oliveira e Costa, Ilhan Kellecioglu and Ryan Weber

NORDREGIO REPORT 2018:1

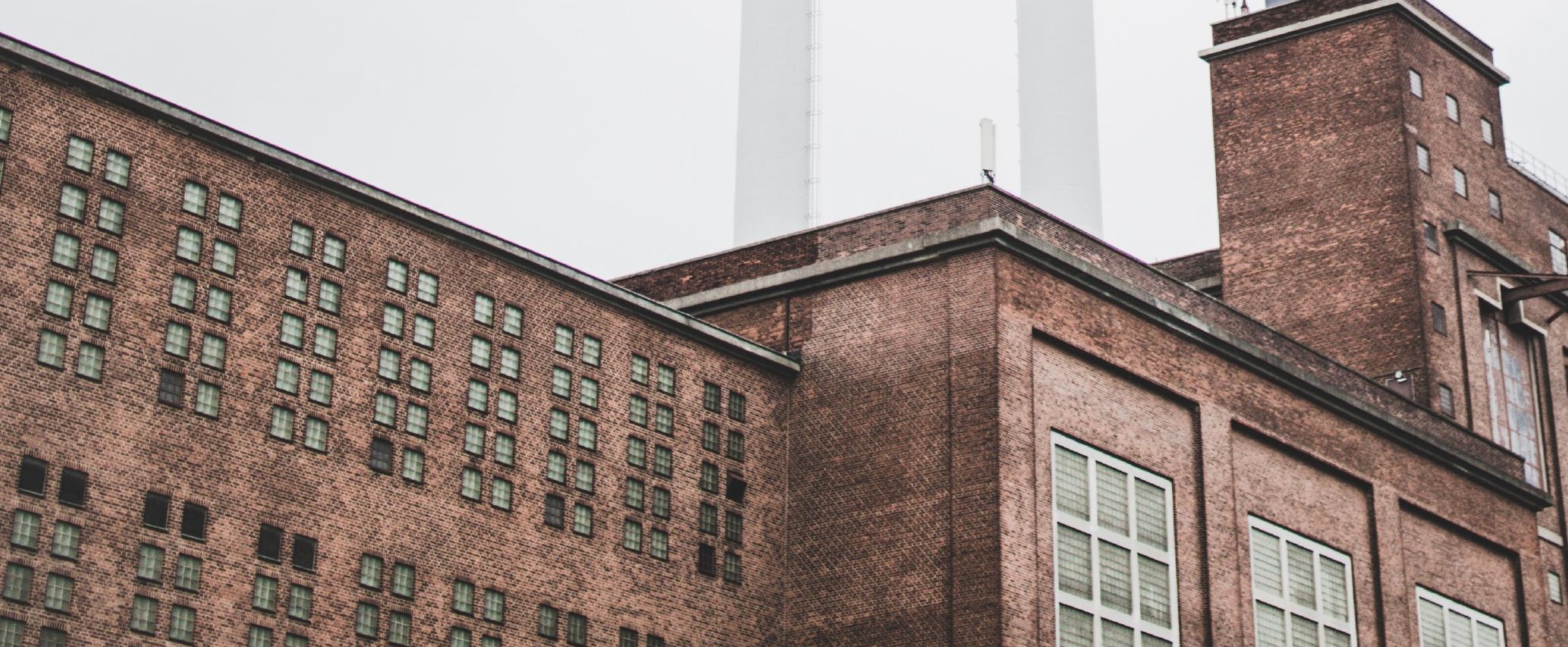





\section{Developing brownfields}

via public-private-people partnerships

Lessons learned from Baltic Urban Lab

Sandra Oliveira e Costa, Ilhan Kellecioglu and Ryan Weber NORDREGIO REPORT 2018:1 
Developing brownfields via public-private-people partnerships

Lessons learned from Baltic Urban Lab

Nordregio Report 2018:X

ISBN978-91-87295-60-7

ISSN: $1403-2503$

DOI: doi.org/10.30689/R2018:1.1403-2503

(c) Nordregio 2018

Nordregio

P.O. Box 1658

SE-111 86 Stockholm, Sweden

nordregio@nordregio.org

www.nordregio.org

www.norden.org

Analyses and text: Sandra Oliveira e Costa, Ihan Kellecioglu and Ryan Weber Cover photo: Daniel Hansen/Unsplash

Repro and print: Allduplo

\section{Nordregio}

is a leading Nordic and European research centre for regional development and planning, established by the Nordic Council of Ministers in 1997. We conduct solution-oriented and applied research, addressing current issues from both a research perspective and the viewpoint of policymakers and practitioners. Operating at the international, national, regional and local levels, Nordregio's research covers a wide geographic scope, with an emphasis on the Nordic and Baltic Sea Regions, Europe and the Arctic.

\section{The Nordic co-operation}

Nordic co-operation is one of the world's most extensive forms of regional collaboration, involving Denmark, Finland, Iceland, Norway, Sweden, and the Faroe Islands, Greenland, and Åland. Nordic co-operation has firm traditions in politics, the economy, and culture. It plays an important role in European and international collaboration, and aims at creating a strong Nordic community in a strong Europe. Nordic co-operation seeks to safeguard Nordic and regional interests and principles in the global community. Common Nordic values help the region solidify its position as one of the world's most innovative and competitive.

\section{The Nordic Council of Ministers}

is a forum of co-operation between the Nordic governments. The Nordic Council of Ministers implements Nordic co-operation. The prime ministers have the overall responsibility. Its activities are co-ordinated by the Nordic ministers for co-operation, the Nordic Committee for co-operation and portfolio ministers. Founded in 1971.

\section{The Nordic Council}

is a forum for co-operation between the Nordic parliaments and governments. The Council consists of 87 parliamentarians from the Nordic countries. The Nordic Council takes policy initiative s and monitors Nordic co-operation. Founded in 1952. 


\section{Contents}

1. Introduction

2. The concept of $4 \mathrm{P}$ in the planning of brownfield areas .................................... 9

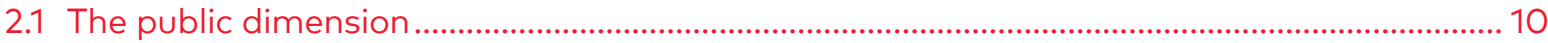

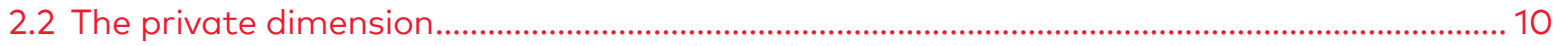

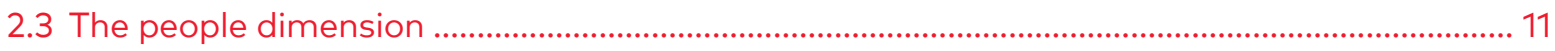

2.4 The dynamics between the three different dimensions.............................................................. 11

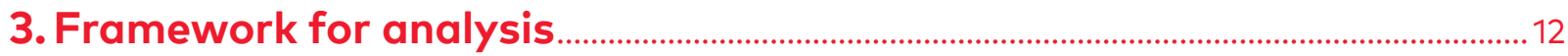

4. Four pilot sites in Baltic Urban Lab ...........................................................................14

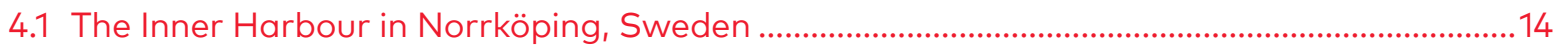

4.2 Skoone Bastion area and Telliskivi in Tallinn, Estonia ......................................................................16

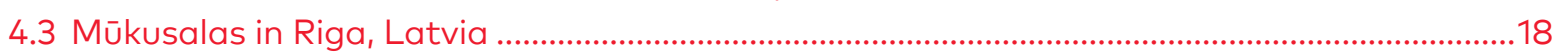

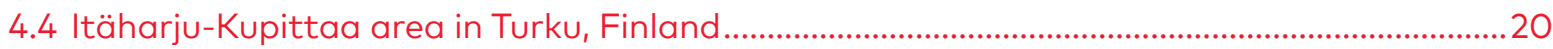

5. Lessons learned in Baltic Urban Lab ...................................................................... 23

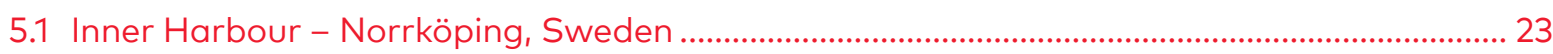

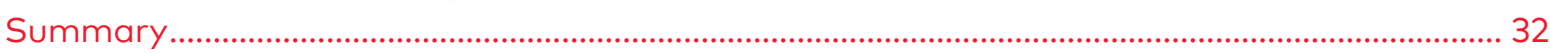

5.2 Skoone Bastion and Telliskivi creative centre - Tallinn, Estonia ............................................. 32

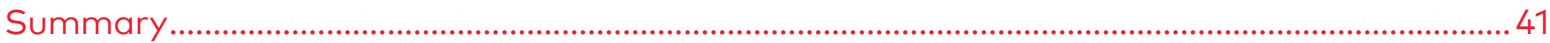

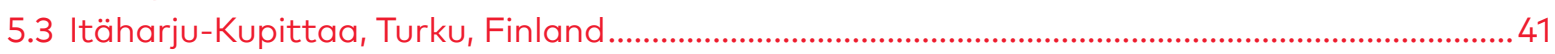

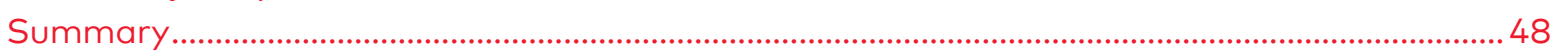

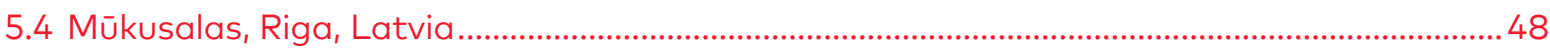

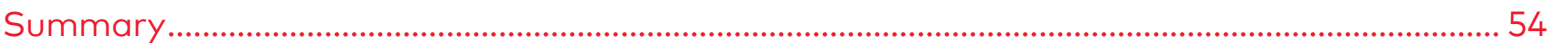

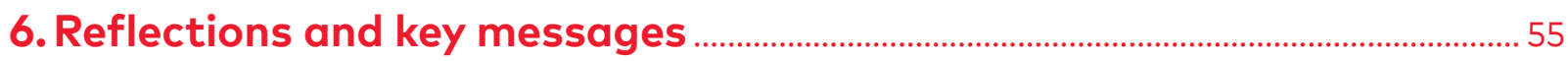

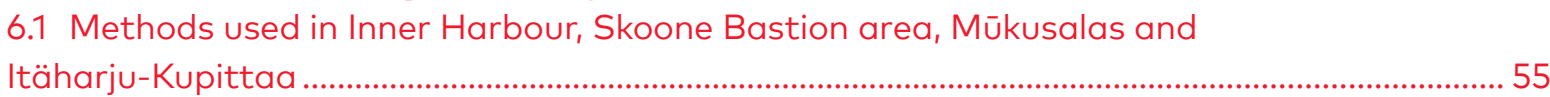

6.2 Public, private and people - different dynamics in the planning process................................ 59

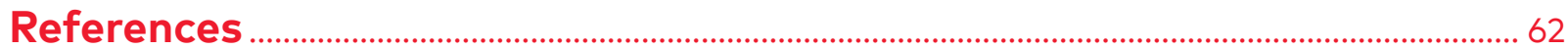




\section{Activities}

\section{Inner Harbour - Norrköping, Sweden:}

Cooperative forum with real estate developers...............................................................................24

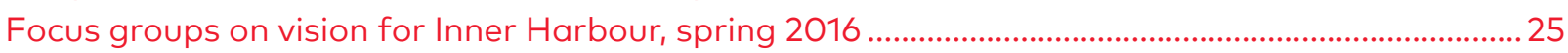

Free boat trip as part of public hearing, August 2016 ......................................................................26

Workshop on risk analysis of alternatives for soil remediation, October 2016 ................................. 27

Seminar on art in urban development, March 2017.............................................................................28

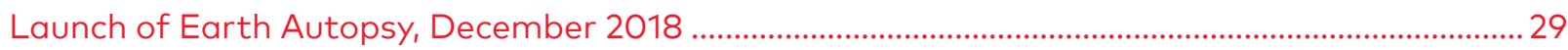

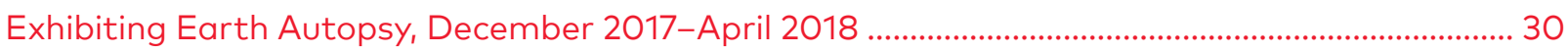

Communication of Inner Harbour through social media - all projects .................................................31

\section{Skoone Bastion and Telliskivi creative centre - Tallinn, Estonia:}

Testing the usefulness of the Tallinn Planning Register, May 2016 ........................................................33

Idea gathering via online GIS map, July-August 2016.............................................................................34

Workshop on terms of reference for AvaLinn, September 2016 ............................................................35

3-day workshop with students and other stakeholders, September 2016 ..........................................36

Presentation of draft version of plan for pilot site, February 2017 .....................................................37

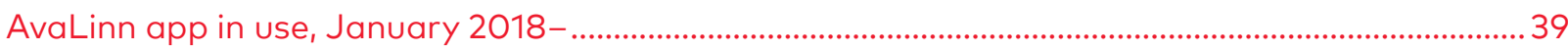

Attempt to set up temporary community gardening, 2017 ................................................................ 40

\section{Itäharju-Kupittaa, Turku, Finland:}

Innovating the future of Kupittaa, May 2016 ................................................................................................ 42

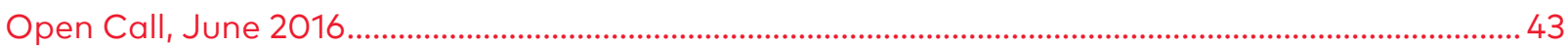

Turku Future Forum, four-day event, November-December 2016 .......................................................44

Initial forum for the landowners and leaseholders, April 2017 ................................................................45

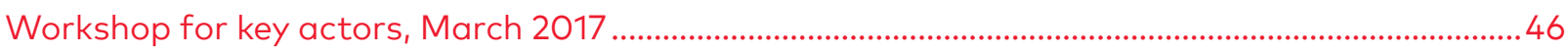

Turku Future Hackathon, three-day competition, September-October 2017 ................................... 47

\section{Mūkusalas, Riga, Latvia:}

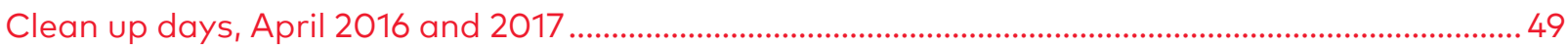

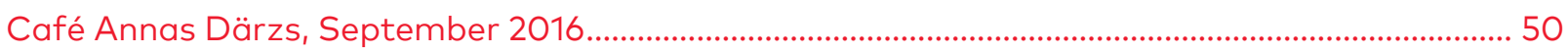

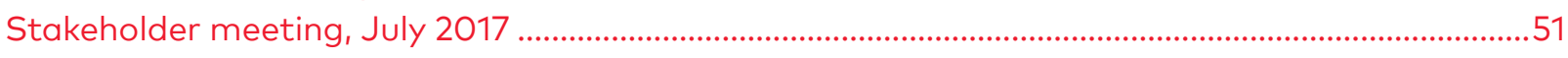

Mūkusalas workshop 2050, December 2017 ................................................................................................... 52

Student competition, September 2017-February 2018 …....................................................................... 53 


\section{Introduction}

\section{Why Baltic Urban Lab EU INTERREG project?}

In the 21st century, urbanisation is continuing and green space in cities is becoming increasingly scarce. Instead of exploiting green spaces and feeding urban sprawl when shaping new city districts, cities can plan for more sustainable development in underused brownfield areas. These are often located close to water and in attractive central locations that were previously used for industrial activities, energy production and shipping. Changing the use of these areas is therefore a strategic choice to satisfy the need for land in growing cities.

However, planning of brownfields is often complex and expensive, involving multiple land owners, potentially serious levels of contamination and an existing infrastructure that is not designed for post-industrial use. Developing an attractive and sustainable land-use and mobility plan that meets the needs of future residents, commercial activities, social services and public spaces requires the vision and expertise of a wide range of actors. Not least, this includes decisive planners and politicians, as well as technical experts and local stakeholders. At present, however, there is no common EU legislation for sustainable landuse - and often, there is no structured approach to brownfield regeneration at national, regional or even local level.

The "people perspective" represents an effort to balance the influence of private actors (landowners, investors, etc.) and the public sector (planners and decision-makers). Baltic Urban Lab has aimed to bridge the gap between city-led and private-led development, in order to find new ways to reach a common vision and understanding by strengthening public-private-people partnerships (also referred to as "4P"). This corresponds to Baltic Urban Lab's objective of improving urban planning in the Baltic Sea region by increasing the capacity of local authorities and planners.

In Baltic Urban Lab, cross-border cooperation has supported cities in their efforts to map challenges and solutions, reflect on lessons learned and better capitalise upon existing good practices.
Between the project kick-off in January 2016 and September 2018, the four local authorities taking part - Norrköping, Riga, Tallinn and Turku - have identified, developed and tested new methods and solutions for planning brownfield sites based on a 4P approach. Many of these are explained in detail and analysed in chapter $5 .{ }^{1}$

\section{Method and material behind the report}

One of Nordregio's tasks in Baltic Urban Lab has been to observe and analyse the methods for stakeholder involvement and participation that the cities tested during the project period. The main approach has been to observe what can be done to involve private actors, local inhabitants and other public departments in the planning process, as well as to understand what can be gained by applying a 4P-approach to the planning of brownfield areas around the Baltic Sea.

The basis for this report consists of earlier publications by Nordregio as part of the Baltic Urban Lab project, two or three follow-up interviews with the local project groups per year, observations and discussions during project meetings, site visits and peer-reviews, and reports on stakeholder involvement that local project groups sent to Nordregio throughout the project, as well as supplementary material such as presentations from meetings, templates for action plans and stakeholder analysis.

\section{Notes to reader}

The target audience for this report consists of local planners seeking to include various stakeholders and establish close cooperation between them. The aim is to share the lessons learned from partner cities in the project, which are of use to other towns and regions in the Central Baltic region, the Nordic Region and throughout Europe.

\footnotetext{
1 Brownfield planning requires a vast number of meetings with stakeholders. Many of these have been carried out within Baltic Urban Lab. This report does not cover all of the innovative activities implemented by local project groups in connection with reaching out to stakeholders and inhabitants. However, it covers a significant number of activities performed between January 2016 to April 2018, and facilitates knowledge-sharing in this area.
} 


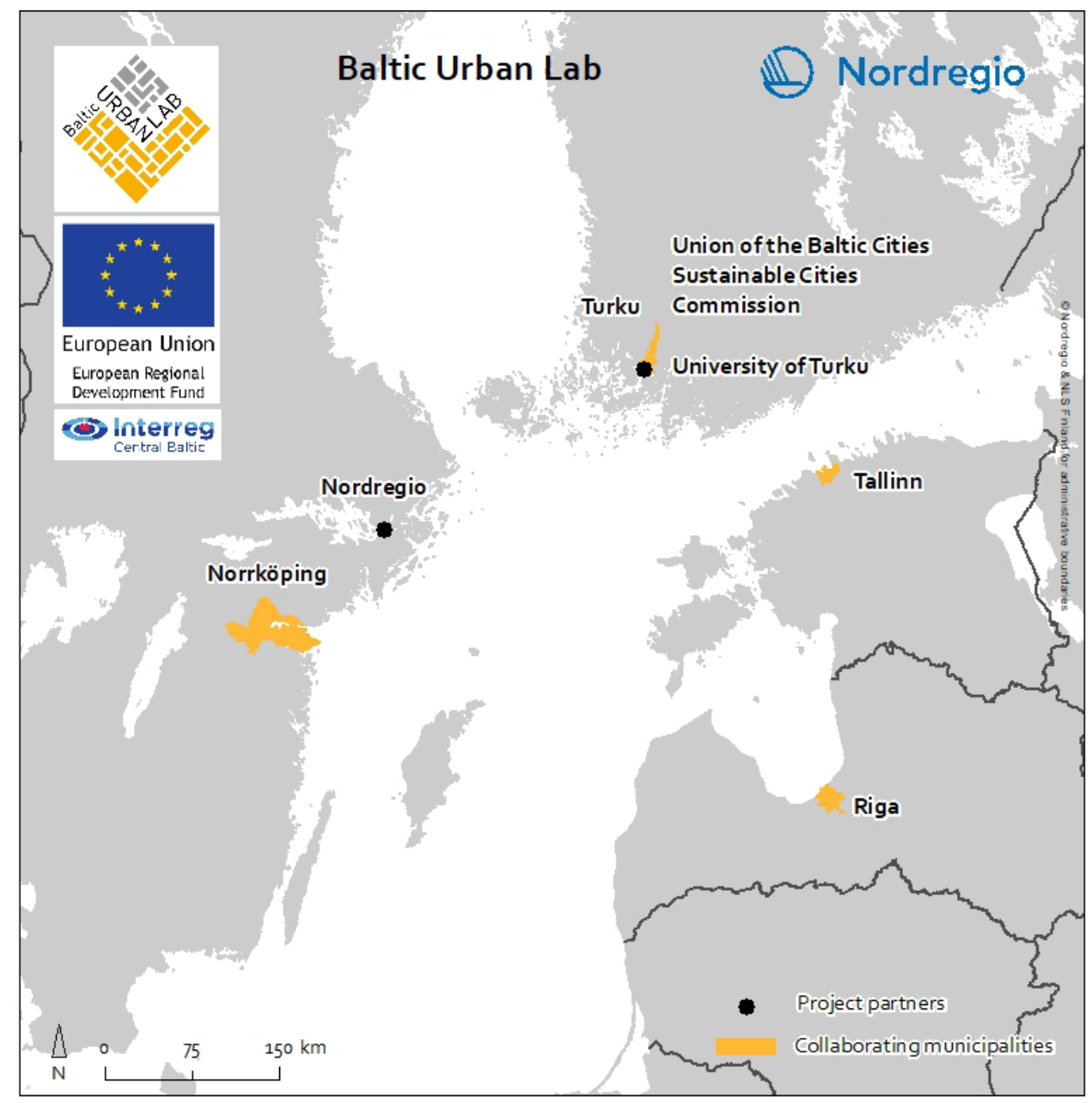

Map 1. Participants in Baltic Urban Lab. Map by Eeva Turunen, Nordregio.

Baltic Urban Lab also has national and regional partners in the participating countries. They play an important role in various aspects of urban development projects, not least when designing guidelines on the planning of brownfield areas. The project outcomes may also be of interest both to students and researchers, as well as to EU programmes that support urban planning projects.

The structure of the report is as follows: Chapter 1 explains the background of the project. Chapter 2 presents the conceptual base for and rationale behind the 4P approach. Chapter 3 introduces the analytical framework used for the analysis of the methods tested by the cities. Chapter 4 introduces each brownfield development site and the most important stakeholders in the respective planning project. In Chapter 5, each method tested is assessed using the democracy cube introduced in chapter 3, and the lessons learned from the cities are presented. Finally, Chapter $\mathbf{6}$ gives space for reflection and key messages about the $4 \mathrm{P}$ approach implemented by each city. The report provides learning and inspiration that can inform the planning of sustainable land use in the 21st century.

Nordregio would like to thank all partners in the project, ${ }^{2}$ as well as all external participants that have contributed to workshops, webinars and site visits during Baltic Urban Lab's four years of intense knowledge-building and exchange.

2 Baltic Urban Lab - Integrated Planning and Partnership Model of Brownfield Development INTERREG Central Baltic 2014-2020. Tallinn Urban Planning Department, Riga City Council City Development Department, the Municipality of Norrköping and the City of Turku each participated in Baltic Urban Lab with a local project group and a brownfield land site that is undergoing planning for future development. Union of the Baltic Cities Sustainable Cities Commission (UBC) has been lead partner, while Brahea Center at the University of Turku participated as knowledge partner. Associated partners have been Turku Science Park, VASAB (Vision and Strategies around the Baltic Sea), Regional Council of South West Finland, BOVERKET (the Swedish National Board of Housing, Building and Planning), Turku Technology Property Group and Tallinn University. www.balticurbanlab.eu 


\section{The concept of $4 \mathrm{P}$ in the planning of brownfield areas}

In an age of decreasing public finances, publicprivate partnerships (also known as PPP or 3P) emerged. The term refers to when public-sector partners work together with private companies to provide products, services and policies. The idea is that such cooperation increases efficiency, adds value and shares the risks between different partners in high-cost projects. However, in the name of market efficiency, public benefits have been discounted in various ways, not least through the handover of planning and design to private developers. While the public sector's role is to ensure commitment to public benefits, publicprivate partnerships have been criticised for lack of transparency in their decision-making, and large-scale projects have been criticised for a focus on increasing land-value rather than prioritising liveability.

Public-private-people partnerships - or 4P have arisen due to this criticism of deficits in transparency and legitimacy, and of the insufficient participation of civil society in planning processes. $4 \mathrm{P}$ adds the people dimension to public-private partnerships. When the citizens are well informed about ongoing change, they can hold public officials accountable. Transparency in public policy and action is therefore believed to result in more responsive and effective governance (Kosack, S. and Fung, A. 2014). Another reason to include citizens in planning processes is that it increases the likelihood of urban development projects resulting in environments and services that correspond to the needs of local people. ${ }^{3}$

\subsection{The public dimension}

The public dimension refers to both the political arena and the public sector. Planners coordinate

\footnotetext{
3 For further reading on the $4 \mathrm{P}$ concept, we recommend Perjo, L., Fredricsson, C., Oliveira e Costa, S. (2016) PublicPrivate-People Partnership in Urban Planning Public-PrivatePeople partnership in urban planning Working paper (Deliverable 2.3.1 Potential and challenges of applying Public-Private-People partnership in urban planning
}

projects involving local-authority departments, and work with regional and national authorities on adherence to legal requirements and political goals. They also procure and coordinate private consultants who help to develop and implement various parts of the planning and construction processes. Figure $\mathbf{1}$ shows, in simplified form, the different actors in the public dimension. In Baltic Urban Lab, the core focus has been on local public administration and civil servants, particularly how they organise and design the planning process together with other stakeholders.

\section{THE PUBLIC SECTOR}

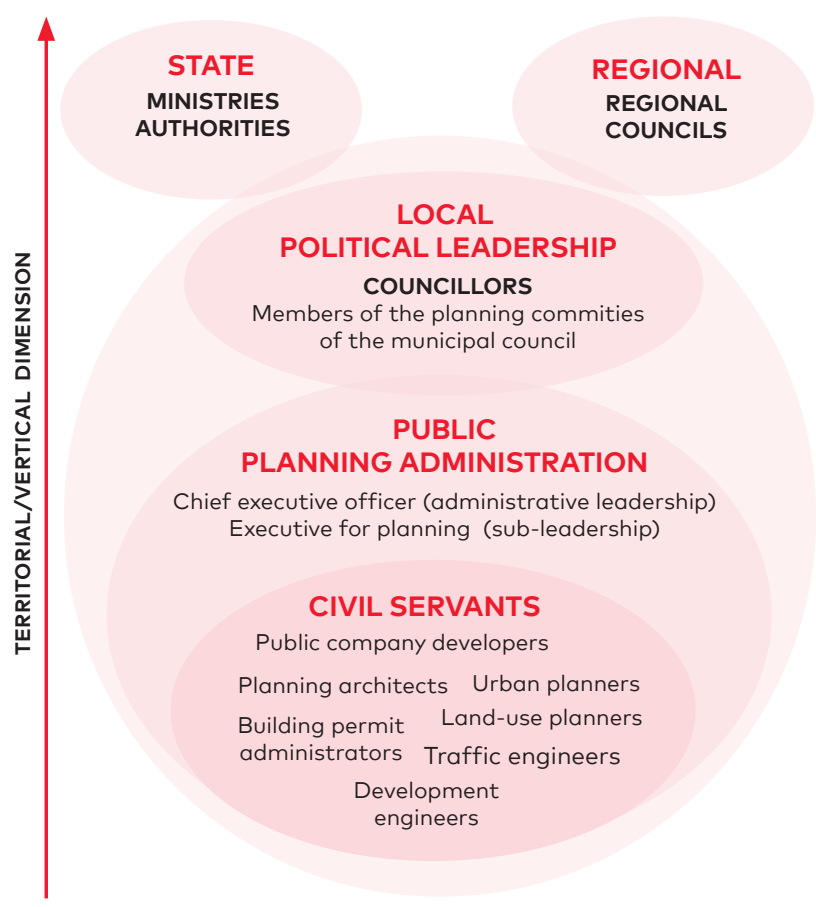

Figure 1. The public dimension in urban development. The figure is a simplified visualisation of the actors in the public dimension based on Hanssen, Kidd (2007) (Perjo, L., Fredricsson, C. and Oliveira e Costa, S. 2016). 


\subsection{The private dimension}

The private dimension refers to the variety of private companies that can participate in the planning process. Consultancies contribute with investigations, assessments or planning documentation; private firms carry out parts of the physical soil preparation; architects design buildings and public space; and construction companies build infrastructure and buildings. As shown in Figure 2 (below), private landowners and companies that have premises in the area are also important stakeholders in brownfield development, since they have a strong legal right to decide on what will happen on the land, and their economic contributions to the overall project will be crucial to its long-term success. Of course, financial institutions such as banks and investors are a crucial component in the realisation of any development project. Public or semi-private companies involved in constructing and/or owning new property can also be considered as belonging to the private dimension due to their profit-seeking economic rationale.

\subsection{The people dimension}

The "people" dimension includes various persons and groups, e.g. existing or future tenants, inhabitants from other parts of the city, and local community groups (such as neighbourhood associations, school parents' groups, and community cultural and recreation associations) as shown in Figure 3. They can also be stakeholders acting as volunteers for the good of the community. At the same time, they represent the people or groups who will use and (hopefully) benefit from a wellbuilt project in the future.

The role of the media is also notable, as it provides an important arena for public debate and for ensuring the transparency of publicly funded projects. Media organisations are difficult to assign to the private dimension since they supervise the actions of the private sector, as well as the public, although they are normally owned by commercial companies. In Figure $\mathbf{3}$ (next page), they are placed on the side of the people dimension and civil society.

\section{THE PRIVATE SECTOR}

PUBLIC AND SEMI-PRIVATE

PUBLIC

LANDOWNERS

Municipal housing companies National \& regional governments Government-owned companies

sis

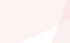

1

PRIVATE

LANDOWNERS

Financiers

Investors
FINANCIAL

INSTITUTIONS

Financiers Investors

Figure 2. The private dimension in urban

development. The figure is a simplified visualisation

of the private sector in urban planning based on

Hanssen, Kidd (2007) (Perjo, L., Fredricsson, C. and

Oliveira e Costa, S. 2016). 
PUBLIC AND SEMI-PRIVATE

\section{MEDIA}

Neighbouring land-owners Neighbouring residentials

\section{EXISTING TENANTS}

LOCAL

COMMUNITY

GROUPS

NGOs

FUTURE

TENANTS

Figure 3: The people dimension

(Perjo, L., Fredricsson, C. and Oliveira e Costa, S. 2016).

\subsection{The dynamics between the three different dimensions}

The public, private and people dimensions have very different roles and associated powers. For example, public institutions often have the political mandate and responsibility for developing a project. The private sector plays an important economic role in urban development, and the public sector is more or less dependent on them performing their work. At the same time, public plans for a development project can sometimes be extremely basic, allowing for a significant degree of leeway for private developer(s) to determine the character of the finished result.

There are clear differences between the people dimension and the public and private. In comparison with public authorities and private stakeholders, it involves people being invited to give input or receive information at a late stage of the planning process when many crucial decisions are taken. While there are usually legal conditions in place to ensure "public hearings" (late) during planning processes, what is considered "participation" is extremely broad. It is seldom clear how input from participatory planning activities will be incorporated into the planning process. ${ }^{4}$ Since formal requirements are rarely placed on how early public participation should work, it can be difficult for both public officials and civil participants to understand the function of participatory practices. As such, the prerequisites for people to participate in planning processes differ substantially from those for actors in the private and public dimensions, not least since the involvement of the latter two tends to be based on formalised agreements.

4 One example is from the mapping of the local authority practice of citizen dialogue in Gothenburg, Sweden, which shows that it is unclear how this practice affects decision-making and that the public administration lacks a common culture about how to set up dialogue processes (Tahvilzadeh, N. 2015) 


\section{Framework for analysis}

Some of the methods or activities tested by the cities have been primarily directed towards the private dimension, others towards the people dimension. Sometimes, the target group has consisted of all three dimensions, and sometimes the activities have been arranged so that the private and people dimension even meet and interact with each other. In order to describe and discuss the processes involved in each of the tested activities in Chapter 5, we take inspiration from the democracy cube. ${ }^{5}$ This tool is used to analyse or design participation in complex governance processes and was developed by Archon Fung, Professor of Democracy and Citizenship at Harvard University (2006). ${ }^{6}$ The democracy cube (albeit not visualised here in the form of a cube) considers various possible choices in order to design governance. It offers three dimensions that can be used to understand what happens in different types of participation settings.

The first dimension concerns who participates and includes the capacity in which participants are invited (e.g. as citizens or elected politicians) and how they are invited. Fung (2006) assumes that the practice of participation is, in some sense, employed to compensate for the existing authority's deficits. Important issues related to the question of who participates are whether the participants represent the relevant population or the general public; if the existing perspectives and interests are represented; whether participants have enough information and knowledge to be able to take decisions; and, finally, whether they are accountable to non-participants.

The second dimension concerns how participants communicate and take decisions. The six different modes of communication and decisionmaking outlined by Fung require different levels of knowledge and engagement from the participants. The first three are merely about how communication works, whereas the latter three also include decision-making.

The third dimension measures what influence participants have over the public decisions and actions. Will participants contribute to making decisions about public policy or actions, or do they participate for the sake of raising their own level of information, but with no expectation of influencing public policy (Fung 2006)?

\footnotetext{
5 The framework for analysis is adapted from a method applied in the ongoing research project The impact of participation: mapping and developing the scope, forms and impacts of the communicative turn in urban planning 2015-0105 financed by The Swedish Research Council Formas.

6 Compared with the widely used Ladder of Participation (Arnstein, S. 1969), this tool not only encompasses citizens and different levels of their impact on policy-making or action, but also allows for the discussion of activities that have previously included only private and public actors. It also unravels different modes of invitation, which is important in terms of understanding who has the opportunity to participate. Since it is not structured as a ladder - which has an inborn symbolic hierarchy, implying that the higher you get, the better it is - the democracy cube can be used instead to account for the dynamics of different participatory activities without intrinsically being normative about their value to the process.
} 
Table 1: The three dimensions in the democracy cube. Based on Fung, A. $(2006 ; 2015) .^{7}$

\section{First dimension - Who participates?}

\begin{tabular}{|c|c|}
\hline $\begin{array}{l}\text { Diffuse public sphere/ } \\
\text { everywhere }\end{array}$ & Mass media and informal platforms of discussion \\
\hline Open, self-selected & $\begin{array}{l}\text { Open to all, but with the downside that the participants who accept } \\
\text { this kind of invitation are seldom representative of any larger public }\end{array}$ \\
\hline Open, with targeted recruitment & $\begin{array}{l}\text { Consciously directing invitations and recruitment towards subgroups } \\
\text { that are less likely to participate palities. }\end{array}$ \\
\hline Randomly selected & $\begin{array}{l}\text { The best way to ensure descriptive representativeness. On the other } \\
\text { hand, when it comes to for example sending out questionnaires, } \\
\text { the response rate can be very low, resulting in a potentially non- } \\
\text { representative selection }\end{array}$ \\
\hline Lay stakeholders & Volunteers that engage in an issue, can be part of an association \\
\hline Professional stakeholders & Private sector officials or paid representatives of organised interests \\
\hline Professional representatives & Politicians \\
\hline Expert administrators & Professional public officials \\
\hline
\end{tabular}

\section{Second dimension - How do participants communicate and take decisions?}

\begin{tabular}{|c|c|}
\hline Deploy technique and expertise & Policies and actions are determined by technical expertise \\
\hline Bargain & $\begin{array}{l}\text { Participants know their standpoint on the issue and bargain among each } \\
\text { other to find the best available alternative. Could be determined by voting. }\end{array}$ \\
\hline Deliberate & $\begin{array}{l}\text { Participants learn about an issue, discuss with each other and can transform } \\
\text { their viewpoints. The aim is to reach agreement (Fung 20O6). Participants } \\
\text { represent different thematic perspectives on the issue (Mansbridge, J. et al. } \\
\text { 2010). }\end{array}$ \\
\hline Develop preferences & $\begin{array}{l}\text { Participants learn about and explore an issue and can transform their views } \\
\text { and opinions. Participants discuss the issues with each other, not merely } \\
\text { listen to presentations by experts. }\end{array}$ \\
\hline Express preferences & Participants express preferences \\
\hline Listen as spectators & Participants receive information \\
\hline
\end{tabular}

\section{Third dimension - What influence do participants have over public decisions and actions?}

\begin{tabular}{|l|l|}
\hline Direct authority & $\begin{array}{l}\text { Participants have substantial authority over financial resources, allowing } \\
\text { them to plan, control and implement }\end{array}$ \\
\hline Co-govern & $\begin{array}{l}\text { Participants join with officials to make plans and policies or develop } \\
\text { strategies }\end{array}$ \\
\hline Advise/consult & $\begin{array}{l}\text { Participants share input that decision-makers commit to receiving. Decision- } \\
\text { makers retain the authority to decide. }\end{array}$ \\
\hline Communicative influence & Decision-makers are affected by general debate and public opinion \\
\hline Individual education & $\begin{array}{l}\text { Participants cannot expect to influence policy and action, but can receive } \\
\text { information of personal benefit }\end{array}$ \\
\hline
\end{tabular}

7 The naming and order of the different categories is updated as per Fung (2015), which differs slightly from Fung (2006). Explanatory texts are based on Fung (2006). 


\section{Four pilot sites in Baltic Urban Lab}

This chapter introduces the pilot areas in the project partner cites: Norrköping in Sweden; Riga in Latvia; Tallinn in Estonia; and Turku in Finland. It describes the location and characteristics of the pilot sites and vision behind Baltic Urban Lab, as well as the main development challenges and the most important stakeholders. Naturally, the four countries' different planning systems affect how local administrations can proceed with the projects ${ }^{8}$.

\subsection{The Inner Harbour in Norrköping, Sweden}

The flooded grazing fields that would later become Norrköping's Inner Harbour began to be developed in the 1600s. A gas works and a wharf operated here between 1800-1970, and since 1970 it has been an industrial area and harbour. Due to severe contamination, the area has almost no biological value. The ground water level is high and climate change poses a flood risk. There are good public

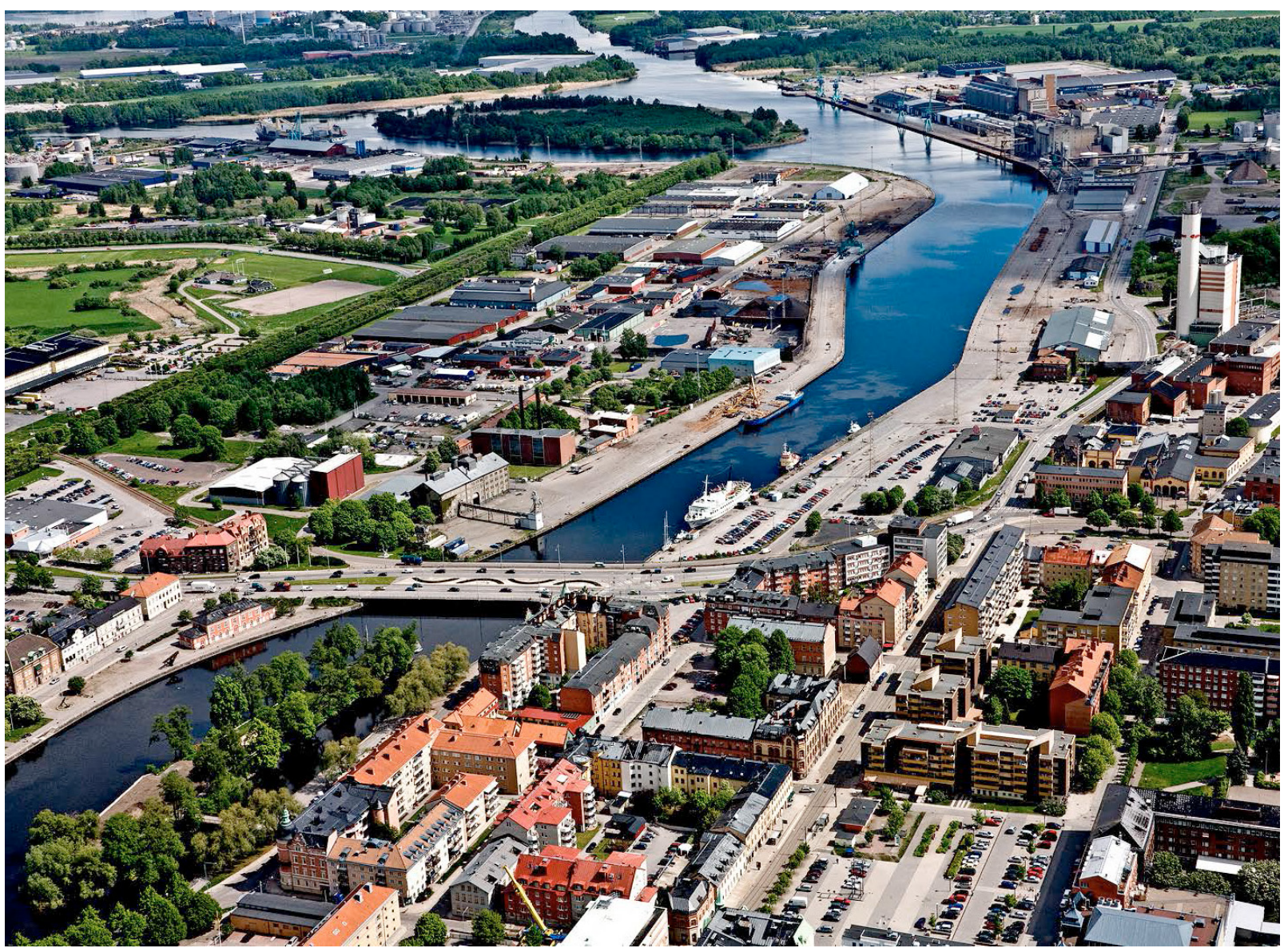

Photo 1. Norrköping's Inner Harbour. Source: City of Norrköping.

8 To get a more in-depth picture of the planning systems in the four countries, see Perjo, L., Fredricsson, C., and Oliveira e Costa, S. (2017) Planning Systems and Legislation for Brownfield Development in the Central Baltic Countries. 


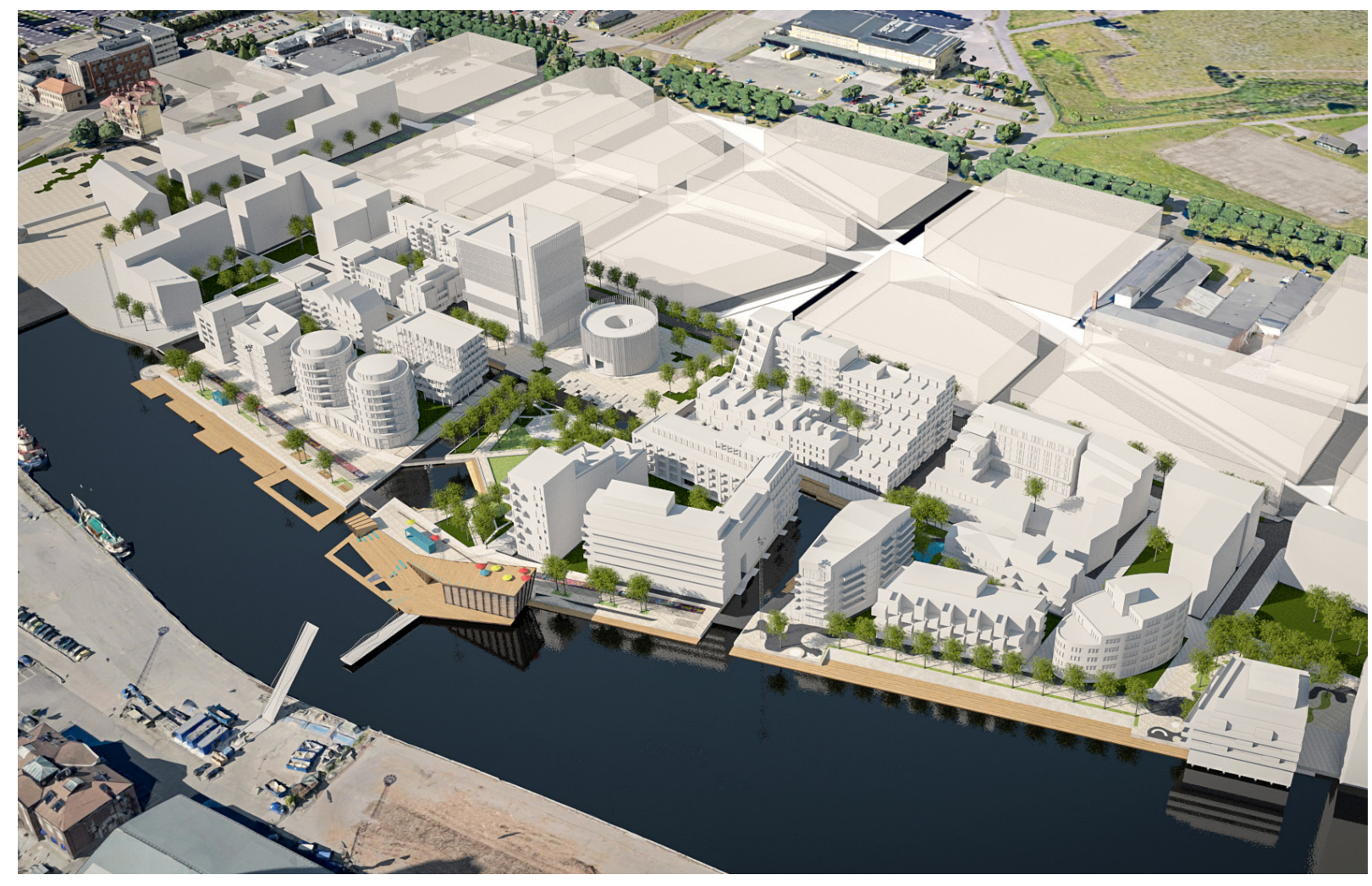

Figure 4. Visualization of the buildings in the first detailed plan. The area has a strategic location in Norrköping, with connections to the Motala River to the south and the large park containing the ruins of Johannisborg Castle to the north. It is also located near the site of the future central station to the north-west, which will be part of the new national high-speed railway system planned through southern Sweden. The "East link" (Ostlänken) will reduce the travel time between the capital and other parts of the region and is expected to contribute to the growth of Norrköping. Source: City of Norrköping.

transport connections, but the walking and cycling infrastructure is poor, and heavy traffic makes the harbour bridge unsuitable for pedestrians. Currently, there are no inhabitants or public services in the area. The Inner Harbour differs from the other pilot sites in Baltic Urban Lab in the sense that great progress had been made on the planning of the area already when starting up Baltic Urban Lab - a vision was already elaborated and the first detailed plan has been finished during the project period.

The vision for Inner Harbour is that it will be an attractive part of the city with mixed functions, including 3,000 apartments combining both public and private housing. The plan also includes new workplaces, public and private services, a marina and new canals. The first detailed plan for the pilot site was approved in June 2018, and the entry date for the new housing is expected to be in 2020.

There are plenty of issues and major problems to tackle. First, increased collaboration between the different political boards in the local area is needed. Currently, each board/department tends to prioritise their own field of responsibility. Second, the development of the Inner Harbour is dependent on long-term investments, whereas politicians tend to think in shorter timeframes that resemble political terms of office. Therefore, one task for the project leader is to make politicians understand and prioritise long-term investments. Third, some of the existing landowners and building users who run activities in the development area will need to move to make space for the vision of the mixed city. For example, activities that present dangers to public health cannot be combined with housing, schools, public spaces, etc. The development of the Inner Harbour is therefore dependent on the local authority's capacity to make detailed plans for these actors' businesses in other parts of Norrköping. Fourth, the effects of soil remediation and construction activities, e.g. noise, smells and traffic, will be felt in other parts of the city. This, coupled with the fact that the project as a whole is a major investment for 
the local authority, makes good communication with the general public and other local public and private actors crucial.

\section{National specificities}

In 2015, the Swedish Environmental Protection Agency set-up a database of contaminated land in Sweden. The same agency provides funding for remediation of these areas. Due to a severe housing shortage, in 2016 the Swedish government established a new fund for remediation of contaminated land, including areas in which local authorities will build housing. The Inner Harbour project received approximately $€ 3.2$ million from this fund.

Local authorities are responsible for spatial planning in Sweden, and tend to own large tracts of land. This has been the case for the first detailed plan in the Inner Harbour, which has given the council a greater say in the details of the urban design. However, in the area of the second detailed plan, private landowners own a larger share of the land and are able to define the development characteristics accordingly.

\section{The most important stakeholders}

At the beginning of the project, the local project group identified the core stakeholders for the planning of the Inner Harbour: the county administrative board of Östergötland, in particular concerning the environmental legislation; the Swedish Maritime Administration, for issues regarding ports and seaways; and local politicians, on issues of local governance, policy-making, social issues, local investments and housing. Other primary stakeholders identified were the Swedish transport administration, for issues on the national rail and road infrastructure; the region of Östergötland, concerning regional development; and the temporary Swedish organisation called Sweden Negotiation, ${ }^{9}$ which handles the nationwide negotiations about the form and financing of the new national high-speed rail infrastructure. Other key stakeholders are the landowners and companies active in the area, like the electric services company E.ON, which has a power plant on the pilot site. The eight real estate developers, as well as local and national media and the residents of Norrköping, are identified as important stakeholders.

9 Translation from Swedish: Sverigeförhandlingen.
Table 2: Core and primary stakeholders identified by local project group

\begin{tabular}{|c|c|}
\hline \multirow[t]{8}{*}{ Public } & $\begin{array}{l}\text { The county administrative board of } \\
\text { Östergötland (core) }\end{array}$ \\
\hline & $\begin{array}{l}\text { The Swedish Maritime } \\
\text { Administration }\end{array}$ \\
\hline & $\begin{array}{l}\text { The Norrköping Port (public owned } \\
\text { company) (core) }\end{array}$ \\
\hline & Local politicians (core) \\
\hline & $\begin{array}{l}\text { The Swedish Transport } \\
\text { Administration }\end{array}$ \\
\hline & The Region of Östergötland \\
\hline & Sweden Negotiation \\
\hline & Professional public officials \\
\hline \multirow[t]{4}{*}{ Private } & Landowners \\
\hline & Companies active in the area \\
\hline & Real estate developers \\
\hline & Contracted architects \\
\hline \multirow[t]{8}{*}{ People } & $\begin{array}{l}\text { Gamla Norrköping (local } \\
\text { association) }\end{array}$ \\
\hline & $\begin{array}{l}\text { Flottans Män (local association for } \\
\text { marine servicemen) }\end{array}$ \\
\hline & $\begin{array}{l}\text { Cityfiske (local association for sports } \\
\text { fishery) }\end{array}$ \\
\hline & Fink (Norrköping birdlife association) \\
\hline & $\begin{array}{l}\text { Skepparsocieteten (association for } \\
\text { harbour workers) }\end{array}$ \\
\hline & Yallah (graffiti organisation) \\
\hline & Miljöpartiet (political party) \\
\hline & Centerpartiet (political party) \\
\hline
\end{tabular}

\subsection{Skoone Bastion area and Telliskivi in Tallinn, Estonia}

The pilot site comprises two different areas: Telliskivi Creative City and the baroque fortification Skoone Bastion. There are only 12 registered inhabitants across the whole pilot site, which is located in a central setting between key areas of the city. Important new city functions are being planned for the two areas, including a new main building for the Estonian Academy of Arts, Tallinn Culture Factory and the Energy Discovery Center Museum, and the new town hall will be sited just next to the area. As a result, there is high development potential and great public interest in how the project will unfold. The site has the potential to create better connections between the central railway station and passenger harbour. A further 


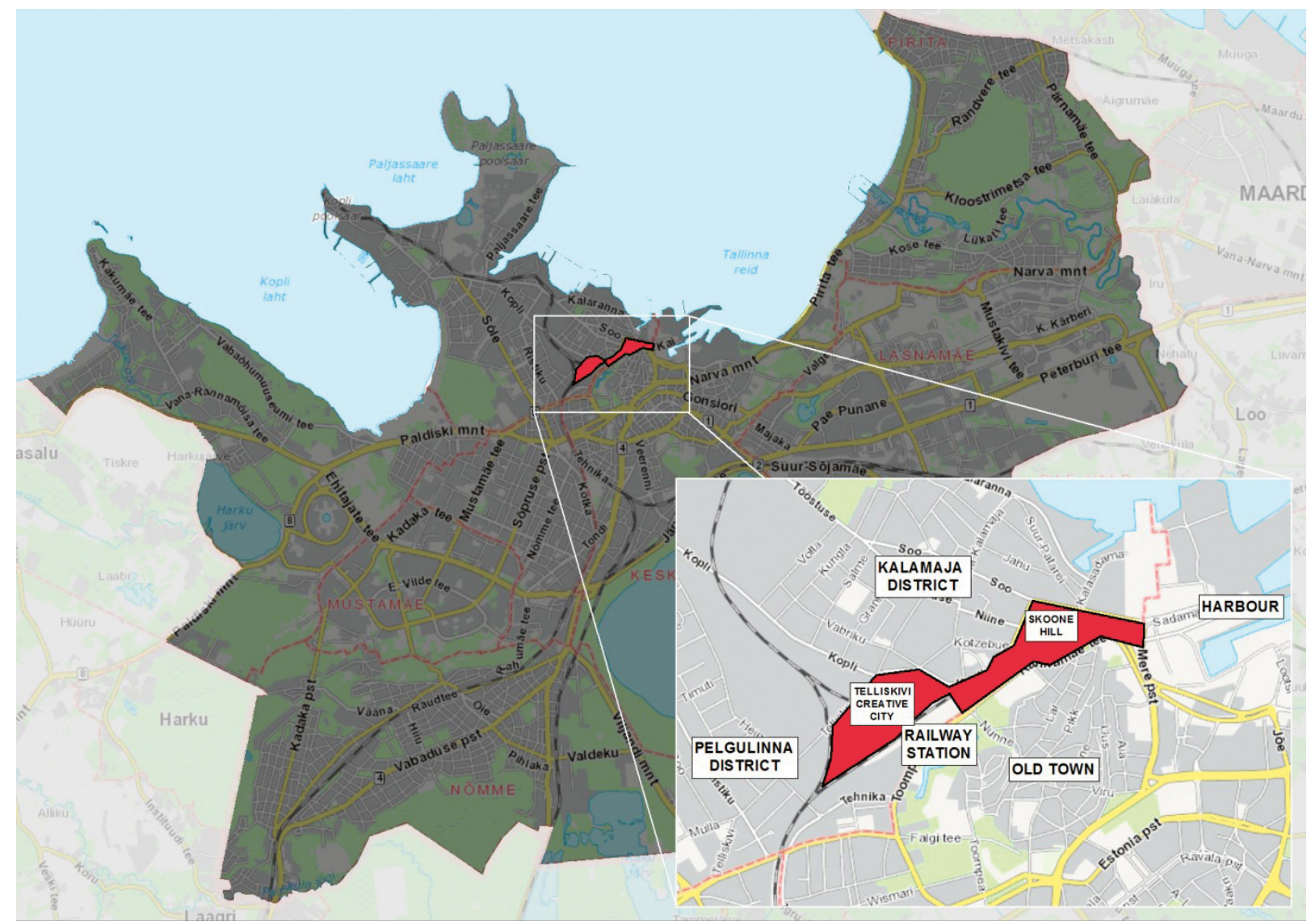

Figure 5. The pilot site is situated in Tallinn city centre, surrounded by the medieval old town, the wood-built area Kalamaja, central railway station, and the passenger harbour. It is close to the main east-west roads out of Tallinn (Põhja pst, Rannamäe tee) and connected to a major intersection (Põhja pst-Mere pst).

Source: www.balticurbanlab.eu.

objective is to improve the connections between the pilot site and the rest of the city.

The Skoone Bastion area comprises a green space flanked by two main roads, a car park, the remains of railway infrastructure and a tramline - all of which make it difficult for pedestrians to access. A large part of it is currently used as a bus station and public parking. The city has a vision to make the area into an urban park, with an underground bus station.

The Telliskivi Creative City area is home to the former Baltic Railway factory. A detailed plan for the area has been in development since 2003, but it needs to be re-evaluated. It has also been undergoing regeneration since 2006 , with private landowners using temporary building permits to open offices, band rehearsal rooms, gyms, studios, galleries, design shops, cafes and restaurants.

The main planning challenges concern traffic and mobility issues - specifically, how to connect the pilot site with the surrounding urban space (residential area, old town, harbour and railway station). A reassessment of existing traffic solutions is needed, and different stakeholders must reach agreement on how to improve the traffic situation, in particular, this concerns the most crucial public departments. A second challenge is that the development of the pilot site is influenced by the fact that it is partly located inside the old town, which is a UNESCO heritage conservation area, entirely within the buffer zone of the old town heritage conservation area. Third, there are multiple challenges associated with creating a common vision with the different stakeholders and ensuring that the developer's plans correspond to the city's visions for the area. Fourth, the area needs strategies for dealing with pollutants.

\section{National specificities}

After the Soviet era, Estonia underwent major land reforms, as a result of which most land, including former industrial sites, was privatised. Today, where responsibility lies for redeveloping 
these sites is often unclear, and improved cooperation between different actors is needed. Estonia has some funding programmes of its own, but the European Regional Development Fund has played an important role in remediation and redevelopment.

\section{The most important stakeholders}

The local project group has identified the core stakeholders as the urban planning department at the City of Tallinn, along with the main landowners and developers. At the next level of importance are various city departments, small landowners, companies active in the area, universities and NGOs. The Skoone Bastion area is mainly owned by the local authority and the state, and the area also has private plots and unreformed land. Telliskivi Creative City is owned by four private landowners. As secondary stakeholders, they identify certain city departments that are not so directly affected, as well as public transport operators.

\section{Table 3: Core and primary stakeholders identified by local project group.}

\begin{tabular}{|c|c|}
\hline \multirow[t]{9}{*}{ Public } & $\begin{array}{l}\text { The Urban Planning Department at } \\
\text { the City of Tallinn (core) }\end{array}$ \\
\hline & $\begin{array}{l}\text { Pohja-Tallinn City District, City of } \\
\text { Tallinn (northern city district) }\end{array}$ \\
\hline & $\begin{array}{l}\text { Kesklinn City District, City of Tallinn } \\
\text { (city centre) }\end{array}$ \\
\hline & $\begin{array}{l}\text { City Property Department, City of } \\
\text { Tallinn }\end{array}$ \\
\hline & Transport Department, City of Tallinn \\
\hline & $\begin{array}{l}\text { Environment Department, City of } \\
\text { Tallinn }\end{array}$ \\
\hline & University (or private?) \\
\hline & National Heritage Board \\
\hline & Estonian Railways Ltd \\
\hline \multirow[t]{3}{*}{ Private } & Big landowners (core) \\
\hline & Small landowners \\
\hline & Companies active in the area \\
\hline \multirow[t]{4}{*}{ People } & $\begin{array}{l}\text { Urban Lab (local urban development } \\
\text { association) }\end{array}$ \\
\hline & $\begin{array}{l}\text { Vanalinna Selts (Old Town Community } \\
\text { NGO) }\end{array}$ \\
\hline & $\begin{array}{l}\text { Telliskivi Selts (Telliskivi Community } \\
\text { NGO) }\end{array}$ \\
\hline & $\begin{array}{l}\text { Jalakäijate ühing (Pedestrian } \\
\text { Community NGO) }\end{array}$ \\
\hline
\end{tabular}

\subsection{Mūkusalas in Riga, Latvia}

Mūkusalas street is the name of a street that runs through the east side of the pilot side, along the river. The pilot site is located on the west bank of the Daugava River, with views towards the city centre (old town). It is situated within the Historic Centre of Riga, which is a designated UNESCO World Heritage Site. It used to be a peripheral area of the city, consisting of gardens and mansions, and was the site of a functioning harbour between 1868 and 1972. Former industrial locations in the neighbouring areas are now slowly turning into office and services clusters, including one science and innovation centre.

The main focus in the Baltic Urban Lab project is to develop a shared development vision for the area, with a high-quality working environment that includes green spaces. The pilot site has direct access to green spaces such as the Kîleveina Ditch, which has the potential to become an appealing recreational spot for people who will work, live and study in the area in the future. It also has the potential to become a unique example of a sustainable rainwater management system. However, to achieve this, the remediation of the Kìleveina Ditch will be necessary. The goal is to create an attractive urban quarter that promotes further business and property investment in the area.

The land-ownership structure of the pilot site is fragmented, and many parallel development processes are currently underway. The main challenge for the process and for the city of Riga is therefore to find a common development vision and strategy for the site, as well to coordinate the parallel processes. The first redevelopment ideas were initiated in 2007 with an international competition to design a new urban development concept for Mūkusalas. The competition winners worked with the local authority to outline a common vision for the site. The vision was approved by Riga City Council and was to be put into practice. However, the ownership structure of the area changed, and the plans were halted.

Based on a private-sector initiative, Riga City Council took a decision in 2012 to elaborate a detailed plan for an area between Jelgavas street (making up the western border of the pilot site) and the Killeveina Ditch. The plan took into account development characteristics and restrictions based on the fact that the site lies within the protection zone of the Historic Centre of Riga. The plan includes 


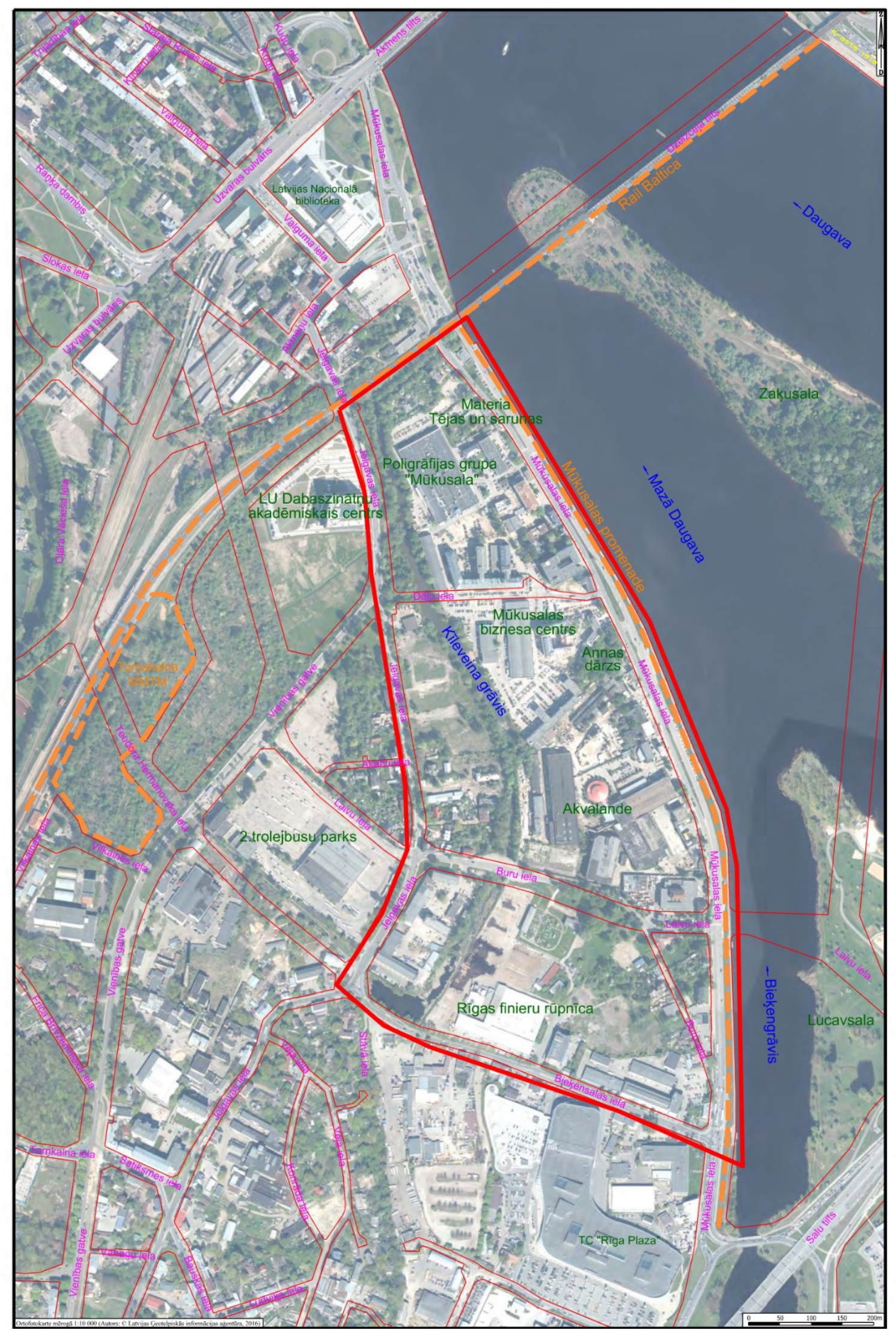

Figure 6. The border of the Mükusalas pilot site is marked in red. To the east is the river and the street after which the pilot area is named. In the centre, the Kilevina ditch flows from north-east to south-west. The western border is made up by Jelgavas street, while to the south is another street, Biekensalas. Source: Riga City Council City Development Department, 2017. 
details on proposed land use, building regulations and the provision of adequate infrastructure.

\section{National specificities}

Large-scale land reforms in the early 1990 s led to significant land privatisation. The ensuing highly fragmented land-ownership structure presents a major challenge in terms of creating viable development strategies for larger areas, including urban districts. On the one hand, the different actors' roles and responsibilities are often unclear, and, there are not enough methods for improving cooperation. On the other hand, there is a lack of financial support for urban development projects, including brownfield developments projects, which are therefore highly dependent on European funds or private contributions from landowners and developers. Funding from European Regional Development Fund has been essential for the remediation and redevelopment of the district in which Mūkusalas is located.

\section{The most important stakeholders}

The City Council and city planning department at the City of Riga, together with the main landowners, are identified as the main stakeholders by the local project group. There are nearly 200 different entities located in the area. The stakeholders involved have been identified either because they own land or because they perform commercial or public service activities at the site. (Table 4, below.)

\subsection{Itäharju-Kupittaa area in Turku, Finland}

Itäharju brownfield site is located close to the Turku Science Park area. The development of the Science Park area is one of four spearhead projects chosen by the city council in spring 2016 . In addition to the existing concentration of office buildings in Itäharju, there is significant potential for further development as an international, high-level competence centre and urban development area. It is also located close to an important transport hub that brings together local pedestrian, cycling, vehicle, bus and rail infrastructure. This includes Kupittaa train station, which is on the line to Helsinki. Plans are currently underway to establish a high-speed service on the Turku-Helsinki link, which makes the site strategically important for future development.

In April 2016, the political decision was taken to develop the Itäharju area as one of the city's "spearhead" urban development projects, and as part of a larger redevelopment of the existing university campus and science park. The larger development area currently has a mix of land uses and building functions, mainly small-scale industry, but also offices, recycling facilities, warehouses, and a bakery, some grocers and other commercial activities.

Prior to the decision in 2016, various stakeholders had initiated discussions about developing the Itäharju area. Multiple visions for redevelopment

\section{Table 4: Core and primary stakeholders identified by local project group.}

\begin{tabular}{|c|c|}
\hline \multirow[t]{6}{*}{ Public } & Riga City Council (performs activities at the site) \\
\hline & National Library (performs activities at the site) \\
\hline & Rigas Satiksme (public transport provider) \\
\hline & Latvian University (national, landowner) \\
\hline & Riga Technical University (national, performs activities at the site) \\
\hline & Latvian Society of Landscape Architecture (national, performs activities at the site) \\
\hline \multirow[t]{2}{*}{ Private } & Mūkusalas Business Center (international, landowner) \\
\hline & $\begin{array}{l}\text { Residents that are not part of any society in the pilot site area but want to be involved in } \\
\text { decisions that affect their daily lives. }\end{array}$ \\
\hline \multirow[t]{5}{*}{ People } & Tuvā Pārdaugava (civil society, national, performs activities at the site) \\
\hline & $\begin{array}{l}\text { Tornakalna Pakavs - society of apartment owners (civil society, local authority, performs } \\
\text { activities at the site) }\end{array}$ \\
\hline & Tornakalna Latvian Association (civil society, local authority, performs activities at the site) \\
\hline & Agenskalns - Our Home (civil society, local authority, performs activities at the site) \\
\hline & GiiBii (civil society, local authority, performs activities at the site) \\
\hline
\end{tabular}




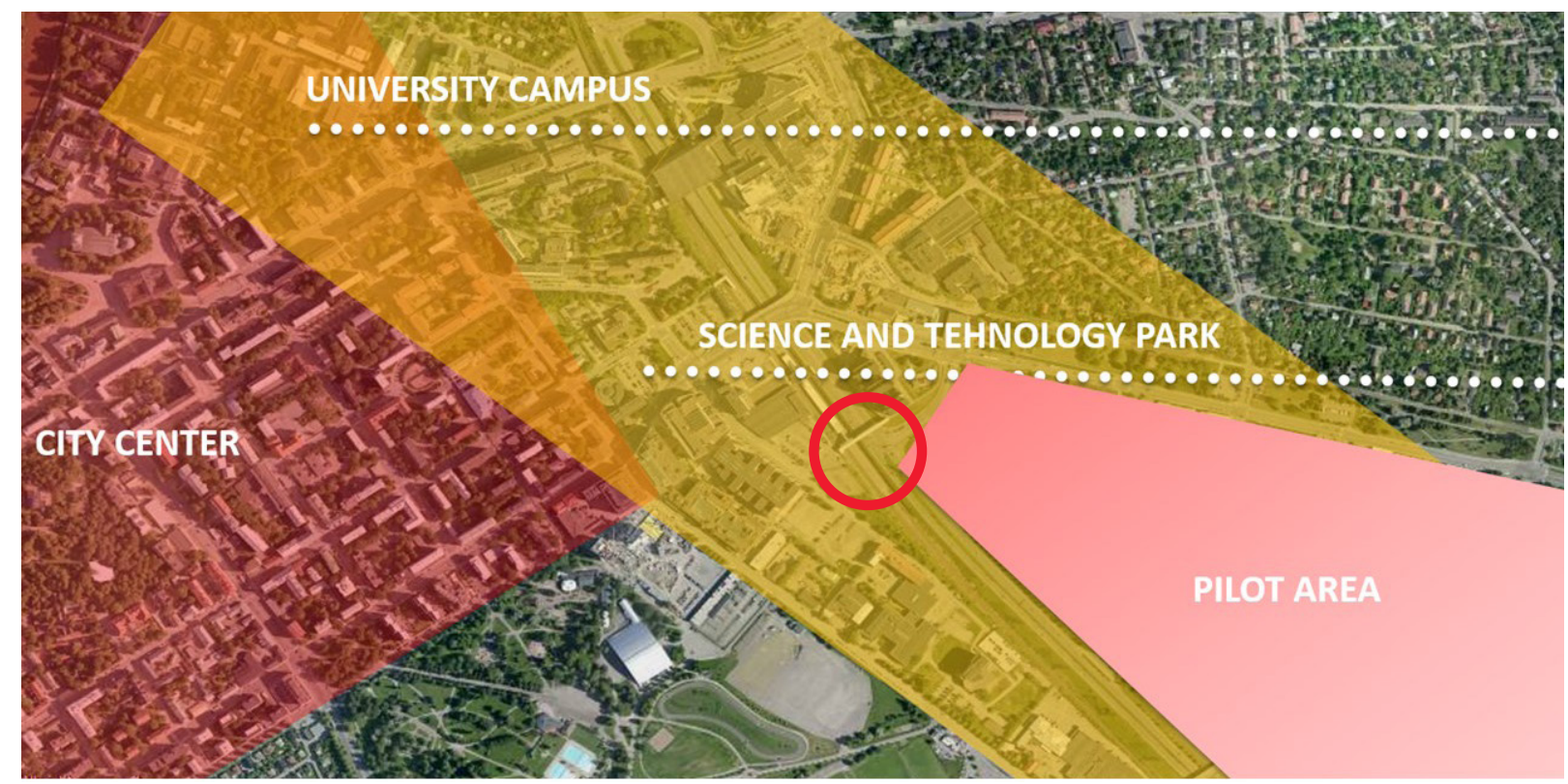

Figure 7. The picture shows the pilot site (pink) and its location in relation to the city centre, the university campus and the science and technology park. The circle shows the location of Kupittaa train station. Source: City of Turku.

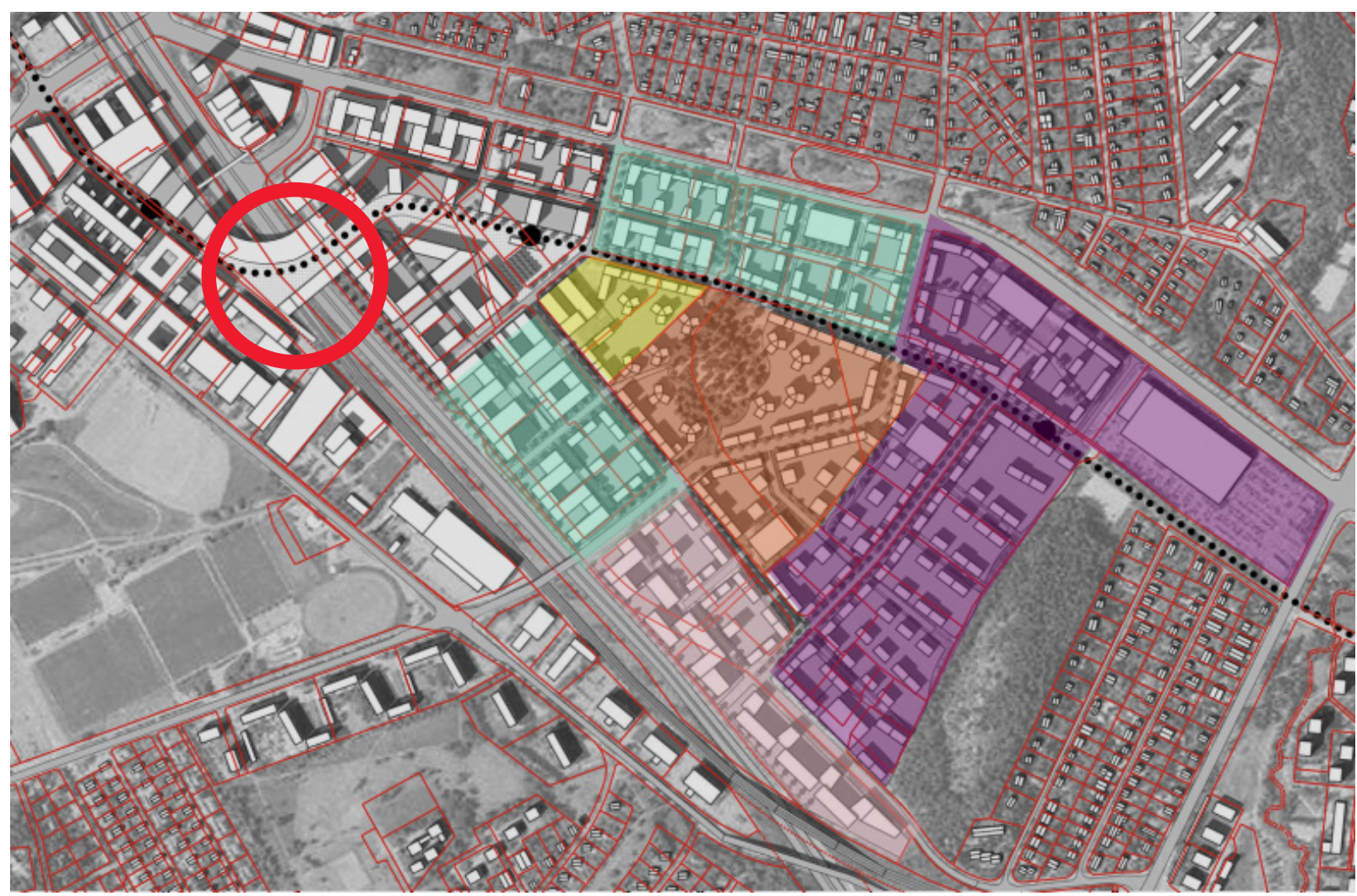

Figure 8. The picture shows a conceptual view of the expected development. The tinted fields indicate different steps in the development. The circle shows the location of Kupittaa train station. Source: City of Turku.

were drawn up, and the city prepared the latest one in connection with plans to reintroduce a tram system in the area. The company running the science and technology park (48\% owned by the city) has also prepared its own vision for extending its activities in the new area. As such, the overall development of the university and science park, including the Itäharju pilot area, is firmly anchored in the city's political system and overall development strategy. 


\section{Highlighted challenges}

There are currently 14 landowners in Itäharju, of which the City of Turku is the largest. However, the city also has long-term rental land contracts with tenants that own the buildings (see Figure 9), including 49 rental contracts for industrial lots and 10 for additional areas or car parks. This constitutes a significant barrier to implementing a comprehensive redevelopment plan for the area. The railway and highway present another great challenge, as they form significant barriers between Itäharju and other parts of the city.

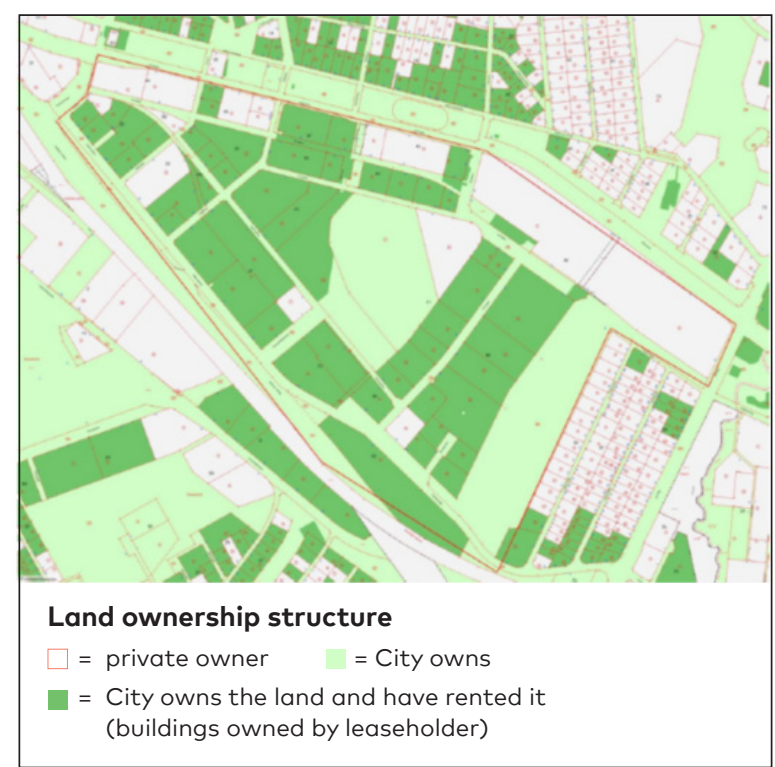

Figure 9. Land ownership structure in Itäharju. Source: City of Turku.

\section{National specificities}

There is no coordinated national policy approach regarding the handling of brownfield development in Finland, nor is there any national database on the number and scope of brownfields. However, in recent years, an increased interest in brownfield redevelopment has emerged - and since 2015, Finland has developed a national risk-management strategy for contaminated land. In addition, two state programmes provide funding to local authorities for the remediation of land. Other state programmes focusing on smart city development also provide funds for the redevelopment of brownfield areas.
Nordic countries such as Finland have a tradition of local authorities with a high level of planning and development autonomy, based on the large amounts of land that they own. As a result, they are able to influence land-use policy and planning projects, including brownfield redevelopment areas. Compared to Latvia and Estonia, the often smaller number of landowners allows for enhanced possibilities for collaboration and consensus building with regard to common strategies. For example, the Finnish Land Use and Planning Act describes methods for cooperation between the local planning authorities and landowners at an early stage in the planning process.

\section{The most important stakeholders for the development}

The city partner has identified the most important core stakeholders for the development of the Itäharju area:

Table 5: Core and primary stakeholders identified by local project group.

\begin{tabular}{|l|l|}
\hline Public & Turku University Properties \\
\hline \multirow{4}{*}{ Turku Technology Properties } \\
\hline & $\begin{array}{l}\text { Turku Science Park } \\
\text { Fospital District of Southwest }\end{array}$ \\
\hline \begin{tabular}{l} 
Universities \\
\hline Turku Region Development Center
\end{tabular} \\
\hline $\begin{array}{l}\text { Various actors within the city } \\
\text { administration and political } \\
\text { decision-makers }\end{array}$ \\
\hline Finnish railway administration \\
\hline Private & Investors \\
\hline Developers
\end{tabular}




\section{Lessons learned in Baltic Urban Lab}

The following sections present the main stakeholder-involvement actions taken by each project partner during the project. All of them occurred during the period between January 2016 and April 2018, and were typically carried out within the context of the pilot sites, as described in the previous section.

Each of the four project partners is described individually. Following a brief introduction, each method and the corresponding steps are explained (About the activity), followed by specific lessons learned from their experience with the local project group (Self-reflection from the city). Each method/step is characterised based on the three dimensions in the democracy cube, as well as on who participates (Participant selection), how they communicate and take decisions, and their degree of influence over public decisions and action (Connection to decisions over the pilot site) (Fung, A. 2006; 2015). Next, the author contributes their own analysis, supported by the democracy cube (Analysis).

Each city's local project group is considered to belong to the category expert administrators (Fung, A. 2006). In all activities, the local project group or other expert administrators from the project are present - and the participants interact with them in different ways. Therefore, we do not mark out the local project group in the analysis, but participants besides these. The focus is on the participants - who are they? How are they able to communicate with each other and with regard to the planning project? What influence do they have over it?

We have noticed that the engagement activities aim to influence three different aspects. These are colour-coded in the analysis. Most of the activities aim to gather input about the planning of the site (blue). Some aim to gather input for the development of a tool for participation (violet), which in turn will be used to gather information about the planning site. A few activities are about activating or drawing attention to the site (yellow).

\subsection{Inner Harbour - Norrköping, Sweden}

When Baltic Urban Lab began, a vision had already been drawn up for the Inner Harbour, and the project group worked closely with the real estate developers on this. During Baltic Urban Lab, the local project group finalised the first detailed plan and held public hearings on it. They also decided which method to use for soil remediation, and the actual remediation process began. A public discussion about the role of the arts in the planning of Inner Harbour has been ongoing, and an internal discussion about how to proceed with the second detailed plan has begun. Throughout Baltic Urban Lab, information about the Inner Harbour project has been communicated via social media, and a new high-tech tool for communicating the project has been developed and tested. 


\section{Cooperative forum with real estate developers}

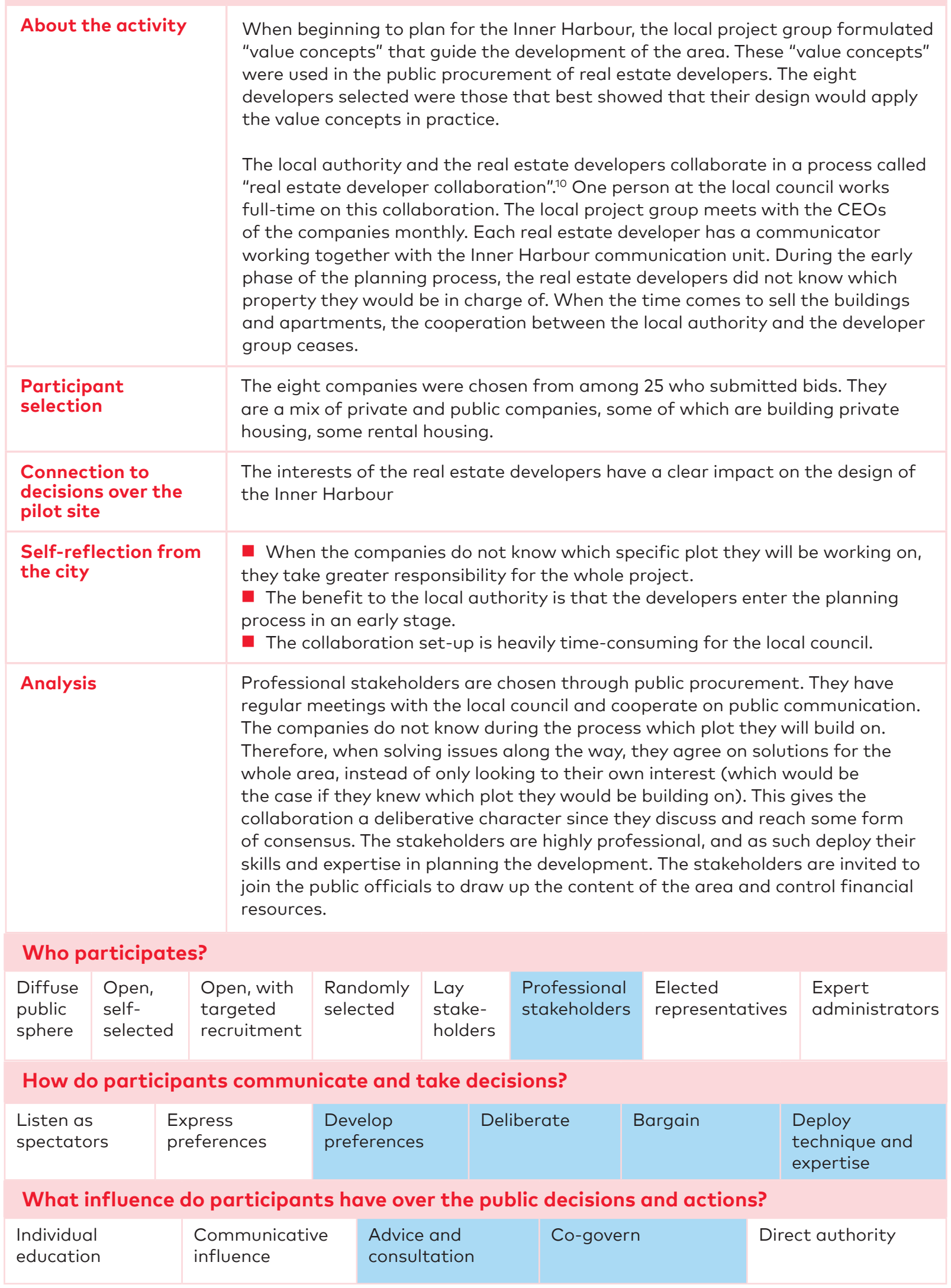

10 In Swedish, "byggherresamverkan". 


\section{Focus groups on vision for Inner Harbour, spring 2016}

About the activity

Participant

selection

The aim was to consult the inhabitants of Norrköping in order to get input on how they perceived the real estate developers' plan to realise the "value concepts" in the design of the Inner Harbour. Prior to the focus group encounters, participants were asked to describe their own understanding of the Inner Harbour and the "value concepts".

The real estate developers financed the focus groups, and a consultant moderated the sessions. Three 1.5-hour focus group encounters were held, each of which was planned by the real estate developers together with the communicator of the Inner Harbour, who is part of the local project group.

The participants totalled 29 men and women aged 15-70. The consultancy and the local council recruited via Facebook. The consultancy also invited "acquaintances" directly or sought participants through them in order to reach missing target groups. Two of the developers invited their tenants.

\section{Connection to decisions over the pilot site}

There is no direct relation to any decisions made regarding the content of the pilot site. The "value concepts" were tested in the focus groups, but discussions were not used to develop or change the concepts. The encounters led to deeper understanding about how to communicate with inhabitants about the project.
Self-reflection from the city
- The results of the focus group will be used in the collaboration with the developers to push for important qualities in the Inner Harbour

- The findings from the focus groups corresponded rather well to what the local council had stated in the value concepts

- The project group gained a more in-depth understanding of which issues the participants considered most important concerning the Inner Harbour - in particular, the problems related to contaminated soils and effective communication strategies.

- The method was not overly costly or time consuming

There is a need for competence/expertise in the conducting of focus groups.

\section{Analysis}

Participants chose to participate after seeing information in social media or through the companies' contact with their tenants. There were also direct invitations from the consultancy, though it is not clear on what basis the invitees were selected. Since the real estate developers themselves participated, professional stakeholders were also present. The setting encouraged participated to express their thoughts about the "value concepts". The activity was used to arrive at a deeper understanding of public opinion, therefore it is here labelled as communicative influence.

\section{Who participates?}

\begin{tabular}{|c|c|c|c|c|c|c|c|}
\hline $\begin{array}{l}\text { iffuse } \\
\text { ublic } \\
\text { shere }\end{array}$ & $\begin{array}{l}\text { Open, } \\
\text { self- } \\
\text { selected }\end{array}$ & $\begin{array}{l}\text { Open, with } \\
\text { targeted } \\
\text { recruitment }\end{array}$ & $\begin{array}{l}\text { Randomly } \\
\text { selected }\end{array}$ & $\begin{array}{l}\text { Lay } \\
\text { stake- } \\
\text { holders }\end{array}$ & $\begin{array}{l}\text { Professional } \\
\text { stakeholders }\end{array}$ & $\begin{array}{l}\text { Elected } \\
\text { representatives }\end{array}$ & $\begin{array}{l}\text { Expert } \\
\text { administrators }\end{array}$ \\
\hline
\end{tabular}

How do participants communicate and take decisions?

\begin{tabular}{|c|c|c|c|c|c|}
\hline $\begin{array}{l}\text { Listen as } \\
\text { spectators }\end{array}$ & $\begin{array}{l}\text { Express } \\
\text { preferences }\end{array}$ & $\begin{array}{l}\text { Develop } \\
\text { preferences }\end{array}$ & Deliberate & Bargain & $\begin{array}{l}\text { Deploy } \\
\text { technique and } \\
\text { expertise }\end{array}$ \\
\hline
\end{tabular}

What influence do participants have over the public decisions and actions?

\begin{tabular}{|c|c|c|c|c|}
\hline $\begin{array}{l}\text { Individual } \\
\text { education }\end{array}$ & $\begin{array}{l}\text { Communicative } \\
\text { influence }\end{array}$ & $\begin{array}{l}\text { Advice and } \\
\text { consultation }\end{array}$ & Co-govern & Direct authority \\
\hline
\end{tabular}




\section{Free boat trip as part of public hearing, August 2016}

\begin{tabular}{|c|c|}
\hline About the activity & $\begin{array}{l}\text { The activity was arranged as a part of the public hearing about the first detailed } \\
\text { plan drawn up for part of the Inner Harbour. The aim was to create public } \\
\text { participation, to collect knowledge and to market the area. For one day, the city } \\
\text { offered seven free boat trips around the harbour and ran information tents on the } \\
\text { quays. Each boat tour lasted } 20 \text { minutes, gave participants a view of the planning } \\
\text { site from the water, and included lectures and opportunities for discussion with } \\
\text { politicians and officials. Representatives from the project organisation, including } \\
\text { the eight developers, the project leader and a soil specialist from the local council, } \\
\text { guided the tours and relayed information about the project. In connection with the } \\
\text { event, the developer group also ran their own exhibition, enabling visitors to pose } \\
\text { questions to them directly. After the public hearing, the project group summarized } \\
\text { the views presented and made some changes to the plan. }\end{array}$ \\
\hline $\begin{array}{l}\text { Participant } \\
\text { selection }\end{array}$ & $\begin{array}{l}\text { Information about the event was spread through media channels, and those } \\
\text { interested had to book a place for the boat trip. A total of } 600-700 \text { passengers } \\
\text { went on the boat trips. Among them were public officials, politicians, local } \\
\text { residents, owners of existing companies in the area, and representatives of the } \\
\text { media. The event generated plenty of media coverage. }\end{array}$ \\
\hline $\begin{array}{l}\text { Connection to } \\
\text { decisions over the } \\
\text { pilot site }\end{array}$ & $\begin{array}{l}\text { sitors could communicate their opinions to the local council via "bottle post" and } \\
\text { e-mail. }\end{array}$ \\
\hline $\begin{array}{l}\text { Self-reflection } \\
\text { from the city }\end{array}$ & $\begin{array}{l}\text { The event generated new ideas, lots of positive feedback, higher degree of } \\
\text { political support and great media attention } \\
\text { It increased the number of people who were informed about the project, both } \\
\text { from direct participation and indirectly through media channels } \\
\text { It was a very effective way to reach new groups of people, e.g. children and } \\
\text { immigrants } \\
\text { Creating availability for participants with disabilities presented a challenge } \\
\text { Arranging this kind of event is time-consuming and expensive. }\end{array}$ \\
\hline Analysis & $\begin{array}{l}\text { General invitations were sent out, which means only those who were interested } \\
\text { attended (self-selection). Professional stakeholders and politicians participated, } \\
\text { too. Participants could receive information, express their thoughts and pose } \\
\text { questions to public and private core stakeholders. Participants got to know } \\
\text { the area and learn about the plans by visiting the pilot site. For those that did } \\
\text { not communicate their views, the motivation to take part in the event could } \\
\text { be increasing their own knowledge. Communicative influence is facilitated due } \\
\text { to the considerable media attention, which contributes to public discussion (in } \\
\text { diffuse public sphere). The influence over the pilot site development takes the } \\
\text { form of advice and consultation, since views are collected for planners to review in } \\
\text { connection with the detailed plan. }\end{array}$ \\
\hline
\end{tabular}

Who participates?

\begin{tabular}{|c|c|c|c|c|c|c|c|}
\hline $\begin{array}{l}\text { Diffuse } \\
\text { public } \\
\text { sphere }\end{array}$ & $\begin{array}{l}\text { Open, } \\
\text { self- } \\
\text { selected }\end{array}$ & $\begin{array}{l}\text { Open, with } \\
\text { targeted } \\
\text { recruitment }\end{array}$ & $\begin{array}{l}\text { Randomly } \\
\text { selected }\end{array}$ & $\begin{array}{l}\text { Lay } \\
\text { stake- } \\
\text { holders }\end{array}$ & $\begin{array}{l}\text { Professional } \\
\text { stakeholders }\end{array}$ & $\begin{array}{l}\text { Elected } \\
\text { representatives }\end{array}$ & $\begin{array}{l}\text { Expert } \\
\text { administrators }\end{array}$ \\
\hline
\end{tabular}

How do participants communicate and take decisions?

\begin{tabular}{|c|c|c|c|c|c|}
\hline $\begin{array}{l}\text { Listen as } \\
\text { spectators }\end{array}$ & $\begin{array}{l}\text { Express } \\
\text { preferences }\end{array}$ & $\begin{array}{l}\text { Develop } \\
\text { preferences }\end{array}$ & Deliberate & Bargain & $\begin{array}{l}\text { Deploy } \\
\text { technique and } \\
\text { expertise }\end{array}$ \\
\hline
\end{tabular}

What influence do participants have over the public decisions and actions?

\begin{tabular}{|c|c|c|c|c|}
\hline $\begin{array}{l}\text { Individual } \\
\text { education }\end{array}$ & $\begin{array}{l}\text { Communicative } \\
\text { influence }\end{array}$ & $\begin{array}{l}\text { Advice and } \\
\text { consultation }\end{array}$ & Co-govern & Direct authority \\
\hline
\end{tabular}




\section{Workshop on risk analysis of alternatives for soil remediation, October 2016}

\begin{tabular}{|c|c|}
\hline About the activity & $\begin{array}{l}\text { The aim was to get a range of angles on possible alternatives to remediation } \\
\text { methods to reduce contamination on the site of the gasworks. It also served as } \\
\text { a basis for decision-making on the optimum remediation alternative. The SAMLA } \\
\text { method was used.1 } \\
\text { The event started with a site visit to the gasworks, followed by a presentation on } \\
\text { the contamination situation and possible remediation methods. Swedgeo intro- } \\
\text { duced the application of the SAMLA method, which the group of stakeholders } \\
\text { would do that afternoon. There were six groups of six participants, representing } \\
\text { different stakeholder interests and competences. By using SAMLA, a total of } 14 \\
\text { aspects of five alternative soil remediation methods were evaluated. The outcomes } \\
\text { were presented at the end of the day, reaching two alternatives for further } \\
\text { evaluation. }\end{array}$ \\
\hline $\begin{array}{l}\text { Participant } \\
\text { selection }\end{array}$ & $\begin{array}{l}\text { The Inner Harbour project group, the water and waste company of Norrköping } \\
\text { council (NOVA), the contracted building companies, consultants (WSP and Sweco) } \\
\text { and authorities such as the County Administration Board of Östergötland and the } \\
\text { Environment Council of Norrköping. In addition, there were experts in geotechnics } \\
\text { and the remediation of contaminated soil, as well as one participant from } \\
\text { Västerås city who works with similar tasks there. }\end{array}$ \\
\hline $\begin{array}{l}\text { Connection to } \\
\text { decisions over the } \\
\text { pilot site }\end{array}$ & $\begin{array}{l}\text { The chosen method for soil remediation in Inner Harbour will affect several aspects } \\
\text { of sustainability for many years. }\end{array}$ \\
\hline $\begin{array}{l}\text { Self-reflection } \\
\text { from the city }\end{array}$ & $\begin{array}{l}\text { Stakeholders expressed gratitude for participating in the event of risk } \\
\text { evaluation. It was an overall success. } \\
\text { Participants increased their knowledge of remediation problems and } \\
\text { possibilities } \\
\text { The largest challenge was obtaining good and easily accessible documentation } \\
\text { One challenge during the event consisted of convincing the participants that } \\
\text { their contribution was important, especially those who do not normally work with } \\
\text { soil remediation. } \\
\text { After the activity, the challenge was how to use the result. The solution was } \\
\text { to run a smaller risk evaluation based on a swot-analysis of the three best } \\
\text { alternatives in a smaller group. }\end{array}$ \\
\hline
\end{tabular}

\section{Analysis}

A large number of professional stakeholders were invited to a well-prepared workshop that increased the participants' knowledge of soil remediation. The method supported deliberate dialogue in which participants could apply their expertise. This led to good advice with regard to the preferred methods. The local project group further elaborated on the analysis and chose one of the suggested methods.

\begin{tabular}{|c|c|c|c|c|c|c|c|}
\hline \multicolumn{8}{|c|}{ Who participates? } \\
\hline $\begin{array}{l}\text { Diffuse } \\
\text { public } \\
\text { sphere }\end{array}$ & $\begin{array}{l}\text { Open, } \\
\text { self- } \\
\text { selected }\end{array}$ & $\begin{array}{l}\text { Open, with } \\
\text { targeted } \\
\text { recruitment }\end{array}$ & $\begin{array}{l}\text { Randomly } \\
\text { selected }\end{array}$ & $\begin{array}{l}\text { Lay } \\
\text { stake- } \\
\text { holders }\end{array}$ & $\begin{array}{l}\text { Professional } \\
\text { stakeholders }\end{array}$ & $\begin{array}{l}\text { Elected } \\
\text { representatives }\end{array}$ & $\begin{array}{l}\text { Expert } \\
\text { administrators }\end{array}$ \\
\hline
\end{tabular}

How do participants communicate and take decisions?

\begin{tabular}{|c|c|c|c|c|c|}
\hline $\begin{array}{l}\text { Listen as } \\
\text { spectators }\end{array}$ & $\begin{array}{l}\text { Express } \\
\text { preferences }\end{array}$ & $\begin{array}{l}\text { Develop } \\
\text { preferences }\end{array}$ & Deliberate & Bargain & $\begin{array}{l}\text { Deploy } \\
\text { technique and } \\
\text { expertise }\end{array}$ \\
\hline
\end{tabular}

11 SAMLA is a method for risk evaluation that the Swedish Geotechnical Institute (Swedgeo) has implemented to Swedish standards http://www.swedgeo.se/sv/produkter--tjanster/ verktyg/samla-fororenade-omraden/. 
What influence do participants have over the public decisions and actions?

\begin{tabular}{l|l|l|l}
$\begin{array}{l}\text { Individual } \\
\text { education }\end{array}$ & $\begin{array}{l}\text { Communicative } \\
\text { influence }\end{array}$ & $\begin{array}{l}\text { Advice and } \\
\text { consultation }\end{array}$ & Co-govern
\end{tabular}

\section{Seminar on art in urban development, March 2017}

\begin{tabular}{|l|l}
\hline About the activity & The aim was to get a range of angles on possible alternatives to remediation \\
A full-day seminar on the role of art and artists in the development of the \\
Inner Harbour. The aim was to inform and create participation with artists \\
from different artistic branches, together with politicians, private developers \\
and interested members of the public. The schedule included lectures, panel \\
discussions and socialising. The topics for discussion were: How to make use of \\
artists' competence and expertise as problem solvers when designing the future \\
Norrköping? What is necessary for creating collaboration between professional \\
groups like architects, urban planners, artists and architectural curators? How \\
can they communicate and understand each other? What challenges can such \\
collaborations meet and overcome?
\end{tabular}

After the seminar, the process of devising an "art programme" for the Inner Harbour began in collaboration with a Danish artist. In the future, artists will be able to report their interest in a public procurement process.

\begin{tabular}{|c|c|}
\hline $\begin{array}{l}\text { Participant } \\
\text { selection }\end{array}$ & $\begin{array}{l}\text { Invitations were sent to specific groups, although the seminar was also open } \\
\text { to the public. The participants included artists and politicians, speakers from } \\
\text { universities and local authorities, and representatives from national level, the } \\
\text { private sector and museums. }\end{array}$ \\
\hline $\begin{array}{l}\text { Connection to } \\
\text { decisions over the } \\
\text { pilot site }\end{array}$ & $\begin{array}{l}\text { Input to the process of elaborating an art programme, which in turn will affect } \\
\text { artistic work in the Inner Harbour. }\end{array}$ \\
\hline $\begin{array}{l}\text { Self-reflection } \\
\text { from the city }\end{array}$ & $\begin{array}{l}\text { It was an explorative event about the role and meaning of art and how to work } \\
\text { with it in urban planning } \\
\text { It functioned as a networking opportunity and communicated the value of art } \\
\text { to local politicians } \\
\text { The outreach was good and the day generated concrete outcomes } \\
\text { Although there is a high level of engagement, there are uncertainties } \\
\text { concerning the political will for funding artistic work } \\
\text { Since this was a new approach, it was not clear what constituted suitable } \\
\text { remuneration for speakers. }\end{array}$ \\
\hline
\end{tabular}

Analysis

Professional stakeholders (artists) were invited, although the seminar was also open for self-selected participation. The classic setting of a seminar and panel debate invites participants to listen and learn, and for some to express their thoughts. Planners were open to communicative influence, and participants could benefit from individual education. The outcome was significant since the seminar contributed to the launch of a process of elaborating an art programme for the Inner Harbour, including strategies on how artistic work will be done in the area.

Who participates?

\begin{tabular}{|c|c|c|c|c|c|c|c|}
\hline $\begin{array}{l}\text { Diffuse } \\
\text { public } \\
\text { sphere }\end{array}$ & $\begin{array}{l}\text { Open, } \\
\text { self- } \\
\text { selected }\end{array}$ & $\begin{array}{l}\text { Open, with } \\
\text { targeted } \\
\text { recruitment }\end{array}$ & $\begin{array}{l}\text { Randomly } \\
\text { selected }\end{array}$ & $\begin{array}{l}\text { Lay } \\
\text { stake- } \\
\text { holders }\end{array}$ & $\begin{array}{l}\text { Professional } \\
\text { stakeholders }\end{array}$ & $\begin{array}{l}\text { Elected } \\
\text { representatives }\end{array}$ & $\begin{array}{l}\text { Expert } \\
\text { administrators }\end{array}$ \\
\hline
\end{tabular}


How do participants communicate and take decisions?

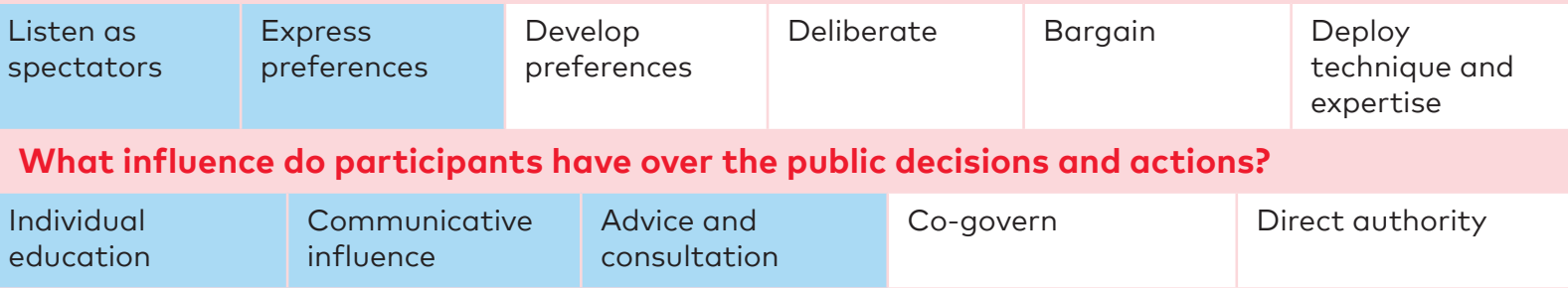

\section{Launch of Earth Autopsy, December 2018}

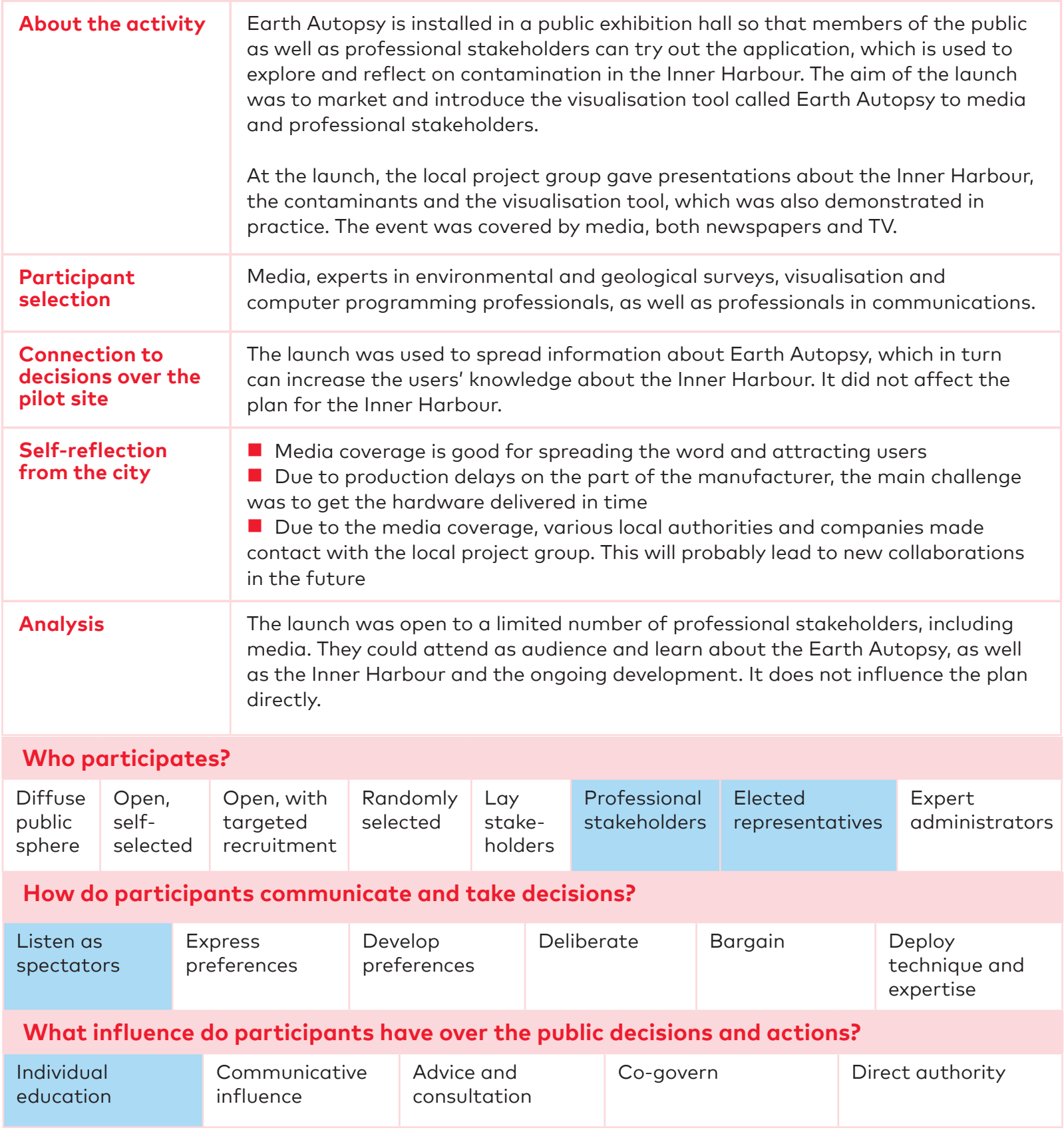




\section{Exhibiting Earth Autopsy, December 2017-April 2018}

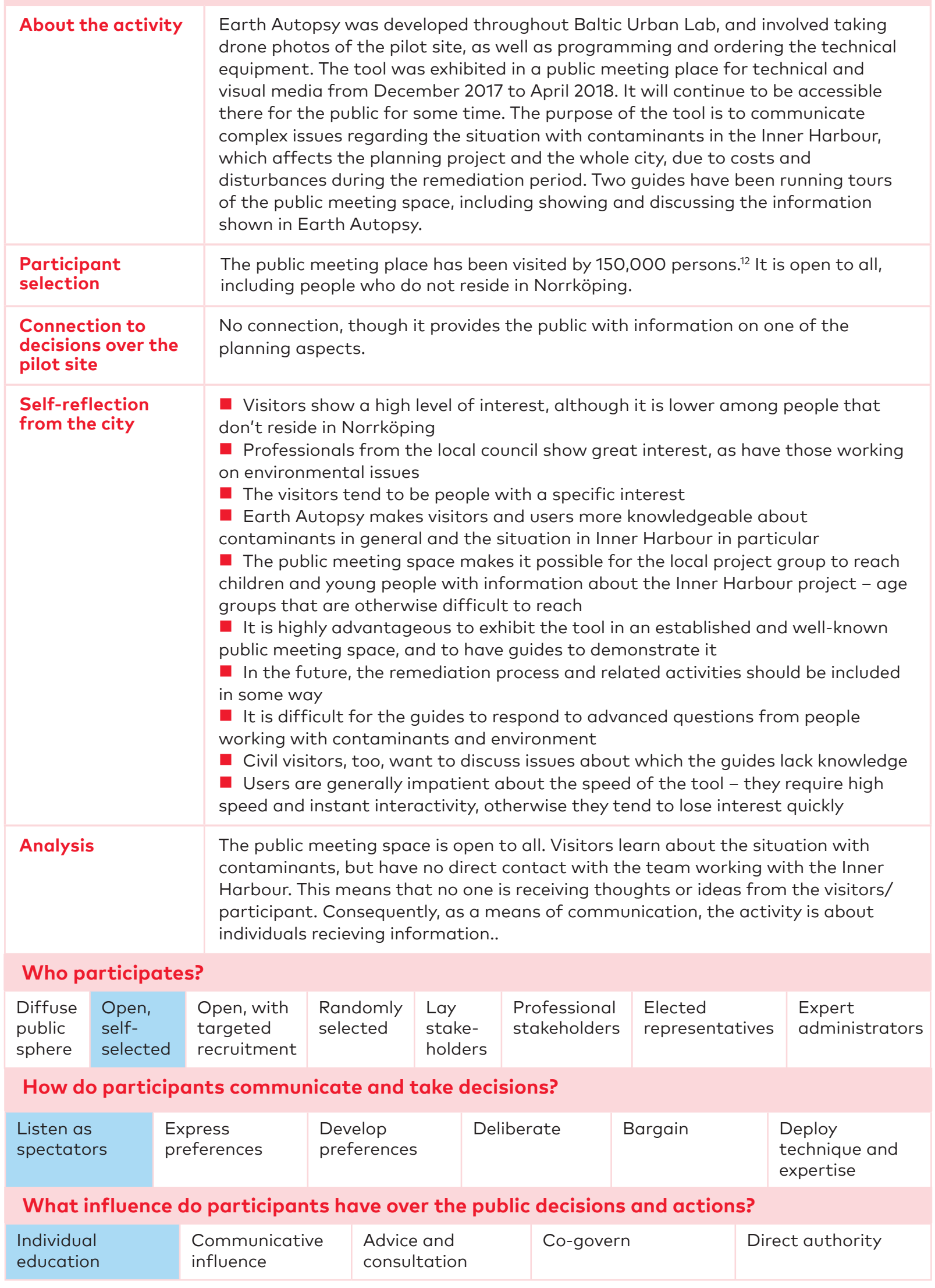

12 No figures are available for how many of these have used Earth Autopsy. 


\section{Communication of Inner Harbour through social media - all projects}

\begin{tabular}{l|l}
\hline About the activity & The purpose of using social media is to quickly and easy disseminate information. \\
Two strategic communicators employed by the local council administer the social \\
media, including planning and posting information on Facebook and answering \\
questions. When necessary, they ask colleagues from the Inner Harbour project \\
for specific information. The Inner Harbour project began using Facebook at its \\
inception in October 2015 and Instagram in October 2016. At first, the project had \\
a unique Instagram account, but it had limited reach, and so posts about the Inner \\
Harbour are instead published through the common account for the city's larger \\
development projects. On average, there is one post per month about the Inner \\
Harbour.
\end{tabular}

Participant selection
The local project group uses the same Facebook page as the local authority, since it is well established, with 20,000 followers. This also allows the project to reach people who have not specifically opted to receive information about the development of the Inner Harbour. Different social media platforms are used to reach specific groups of stakeholders (categorised by age, gender, nationality, level of education, etc.).

\section{Connection to decisions over the pilot site}

\section{Self-reflection} from the city
According to the project group (stakeholder involvement report), the input shows that the public is "very interested" in the development and the vast majority are "very supportive of the project". Some people are worried about rising water levels in the future. Some people are negative towards the development, as they consider the area to be only for the rich.

- The vast majority of respondents on social media express a positive attitude towards the project.

- There are more negative remarks on Facebook. A possible explanation for this is the greater number of followers on Facebook

- Social media has made it possible for the project to reach more than 100,000 unique individuals.

- $60 \%$ of the followers are women

- A strong incentive is the availability and flexibility since people may choose for themselves when and to what extent they are interested in information.

- Social media makes it possible to interact in discussions and to answer all kinds of questions from the public.

- Questions and answers are visible to all.

- Social media requires a lot of resources, in terms of allocating staff to answer questions. Discussions on the internet are on-going $24 / 7$ all year round, and must be maintained even when staff are on leave.

- Acquiring new followers takes time and effort.

- Some colleagues, contractors and architects are concerned about posting ideas at an early stage, so getting members of the project to use social media has proved challenging.

Analysis
Sharing information on social media means communicating via the diffuse public sphere (discussions on the internet). Those exposed to the information are supposedly people who have chosen to follow the Facebook page and Instagram accounts. However, they also reach users who follow the local authority accounts also for other reasons. In this sense, the social media reach is wider than the already interested public. It is possible to learn about the project, i.e. as a spectator, and to benefit from the information as a private person, but also to express preferences through comments or pose questions. Communication officers and members of the Inner Harbour planning project can answer questions, and as such can be affected by communicative influence. 


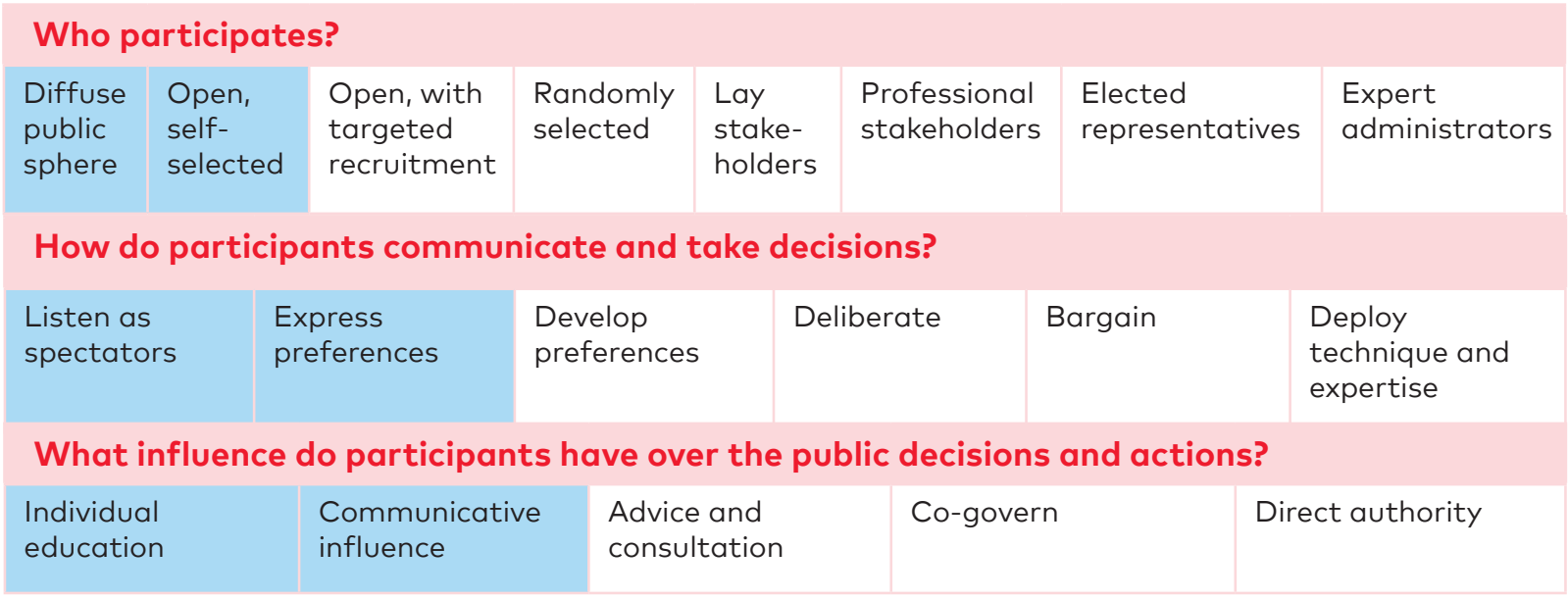

\section{Summary}

The activities covered in the analysis together encompass most of the categories in Fung's analytical model. This shows that the Inner Harbour project uses multiple types of participatory activity. However, there has not been a specific focus on what Fung calls "lay stakeholders", even though the stakeholder analysis at the beginning of the project identified various associations.

Apart from the social media activities, which are largely directed towards the diffuse public sphere, all activities have been directed towards professional stakeholders. The risk-evaluation workshop was directed towards other experts, while the launch of the Earth Autopsy was directed towards both experts and politicians. On the other hand, the focus group, the public hearing on a boat and the seminar on art were directed towards the general public, using both open self-selection and directed recruitment of specific groups or individuals.

The more advanced methods for participation, touching on deliberation and co-governance, have been applied in the collaboration with professional stakeholders in the process with real estate developers and in the risk-evaluation workshop. Activities directed towards the public have been about creating space for learning and expressing thoughts (preferences). The Inner Harbour project developed the local council's knowledge about the reach of social media, when it is used and how. When it comes to interaction with the public, the purpose of the activities has been to create transparency and reach out with accessible information in various channels. It has not been about including the public in innovative processes for influencing the planning more specifically. However, a well-informed public enables citizens to be active in the development of the city, which in turn contributes to transparency.

All of the activities, with the exception of the focus group, were concerned to different degrees with expressing preferences regarding the planning of the site. While the focus group was about the value concepts in the vision for the site, these had already been decided upon. Rather, the event was used to get a deeper understanding of how to communicate some of the aspects of the planning project. The seminar on art was planned and conducted without the organisers knowing where it would lead, but it was receptive to communicative influence about the role of art in the future planning and design of the area.

\subsection{Skoone Bastion and Telliskivi creative centre - Tallinn, Estonia}

Land in Tallinn is generally privately owned, so private owners and developers are often the main drivers of urban development. During detailed planning processes, private owners usually take the initiative to present development ideas and proposals to city officials. The city government or council then assess whether the proposals fit into the aims and objectives of the local master plan. In the case of Tallinn, the objective of Baltic Urban Lab is to strengthen the city's coordinating role, including via outreach to citizens and NGOs. The process of planning the pilot site began with a series of meetings in small groups with different stakeholders in order to map their ideas. This provided a base for drafting the structural plan. 
Efforts have been made to develop new digital tools for the public to learn about ongoing planning work, and to enable them to comment on the suggestions from the city. The AvaLinn app was developed and tested during Baltic Urban Lab. There have also been attempts to make the pilot site more accessible to citizens during the planning process.

\section{Testing the usefulness of the Tallinn Planning Register, May 2016}

\begin{tabular}{|c|c|}
\hline About the activity & $\begin{array}{l}\text { During three weeks in May 2016, an online survey about the user experience of } \\
\text { the Tallinn Planning Register tool was open to all. The planning register provides } \\
\text { information about both general and detailed plans. The aim of the survey } \\
\text { was to get input about the user-friendliness of and potential interest in the } \\
\text { AvaLinn mobile phone app, as well as to understand the future users' needs and } \\
\text { expectations in relation to a new tool. A total of } 212 \text { people completed the survey. } \\
\text { Younger respondents were more positive to a mobile app than older respondents. } \\
\text { The local project group found that it was difficult to get "a person from the street" } \\
\text { to answer to the survey. One important conclusion from the survey was that there } \\
\text { is a need for a simple and user-friendly tool that enables a broad audience to give } \\
\text { their opinion on public space planning. The Tallinn Planning Register is a specific } \\
\text { tool, and not widely used. The register also looks quite difficult to navigate, which } \\
\text { might discourage some users. }\end{array}$ \\
\hline $\begin{array}{l}\text { Participant } \\
\text { selection }\end{array}$ & $\begin{array}{l}\text { The survey was communicated through various channels: Tallinn city web page, the } \\
\text { council's intranet news section, Tallinn Täna Facebook page, Pöhja-Tallinn district } \\
\text { webpage and city-planner mailing lists. However, the local project group found } \\
\text { that reaching the "average person" (not a city-planner, architect, developer etc.) } \\
\text { was a challenge }\end{array}$ \\
\hline $\begin{array}{l}\text { Connection to } \\
\text { decisions over the } \\
\text { pilot site }\end{array}$ & $\begin{array}{l}\text { It is a way to understand the future users of the AvaLinn mobile phone app. Not } \\
\text { connected to any decision over the plan. }\end{array}$ \\
\hline $\begin{array}{l}\text { Self-reflection } \\
\text { from the city }\end{array}$ & $\begin{array}{l}\text { User-friendliness is of the utmost importance } \\
\text { Difficult to reach and motivate the general public to answer to such survey. }\end{array}$ \\
\hline Analysis & $\begin{array}{l}\text { The survey gives the opportunity to express thoughts regarding the use of the } \\
\text { Tallinn Planning Register and is a way of consulting participants in order to get } \\
\text { a better understanding of what form a successful tool for collecting input from } \\
\text { citizens could take. Any participant who received the information could take part, } \\
\text { subsequently meaning those were persons who for some reason had interest in it. }\end{array}$ \\
\hline
\end{tabular}

\section{Who participates?}

\begin{tabular}{|c|c|c|c|c|c|c|c|}
\hline $\begin{array}{l}\text { Diffuse } \\
\text { public } \\
\text { sphere }\end{array}$ & $\begin{array}{l}\text { Open, } \\
\text { self- } \\
\text { selected }\end{array}$ & $\begin{array}{l}\text { Open, with } \\
\text { targeted } \\
\text { recruitment }\end{array}$ & $\begin{array}{l}\text { Randomly } \\
\text { selected }\end{array}$ & $\begin{array}{l}\text { Lay } \\
\text { stake- } \\
\text { holders }\end{array}$ & $\begin{array}{l}\text { Professional } \\
\text { stakeholders }\end{array}$ & $\begin{array}{l}\text { Elected } \\
\text { representatives }\end{array}$ & $\begin{array}{l}\text { Expert } \\
\text { administrators }\end{array}$ \\
\hline
\end{tabular}

\section{How do participants communicate and take decisions?}

\begin{tabular}{|c|c|c|c|c|c|}
\hline $\begin{array}{l}\text { Listen as } \\
\text { spectators }\end{array}$ & $\begin{array}{l}\text { Express } \\
\text { preferences }\end{array}$ & $\begin{array}{l}\text { Develop } \\
\text { preferences }\end{array}$ & Deliberate & Bargain & $\begin{array}{l}\text { Deploy } \\
\text { technique and } \\
\text { expertise }\end{array}$ \\
\hline
\end{tabular}

\section{What influence do participants have over the public decisions and actions?}

\begin{tabular}{|c|c|c|c|c|}
\hline $\begin{array}{l}\text { Individual } \\
\text { education }\end{array}$ & $\begin{array}{l}\text { Communicative } \\
\text { influence }\end{array}$ & $\begin{array}{l}\text { Advice and } \\
\text { consultation }\end{array}$ & Co-govern & Direct authority \\
\hline
\end{tabular}




\section{Idea gathering via online GIS map, July-August 2016}

About the activity

Testing of a new method to gather input to the Northern Tallinn general plan, within which the pilot site is located. Users could select a location on an online GIS map, describe their ideas in a text box and then submit the idea. Officials from Tallinn Urban Planning Department analysed the input and categorised the status of the ideas as either accepted, forwarded, to be confirmed or declined, which enabled citizens to see how their proposal had been received. Accepted means the proposal was included in the general plan for Northern Tallinn. Anyone could see the ideas pinned to the map and how they were categorised by the city organisation. Most suggestions concerned a lack of green areas and parks, the need for better maintenance of playgrounds, poor road conditions, traffic problems and parking management. Officials forwarded issues belonging to other council departments.

trum Ideekorje Pốhja-Tallinna üldplaneeringule

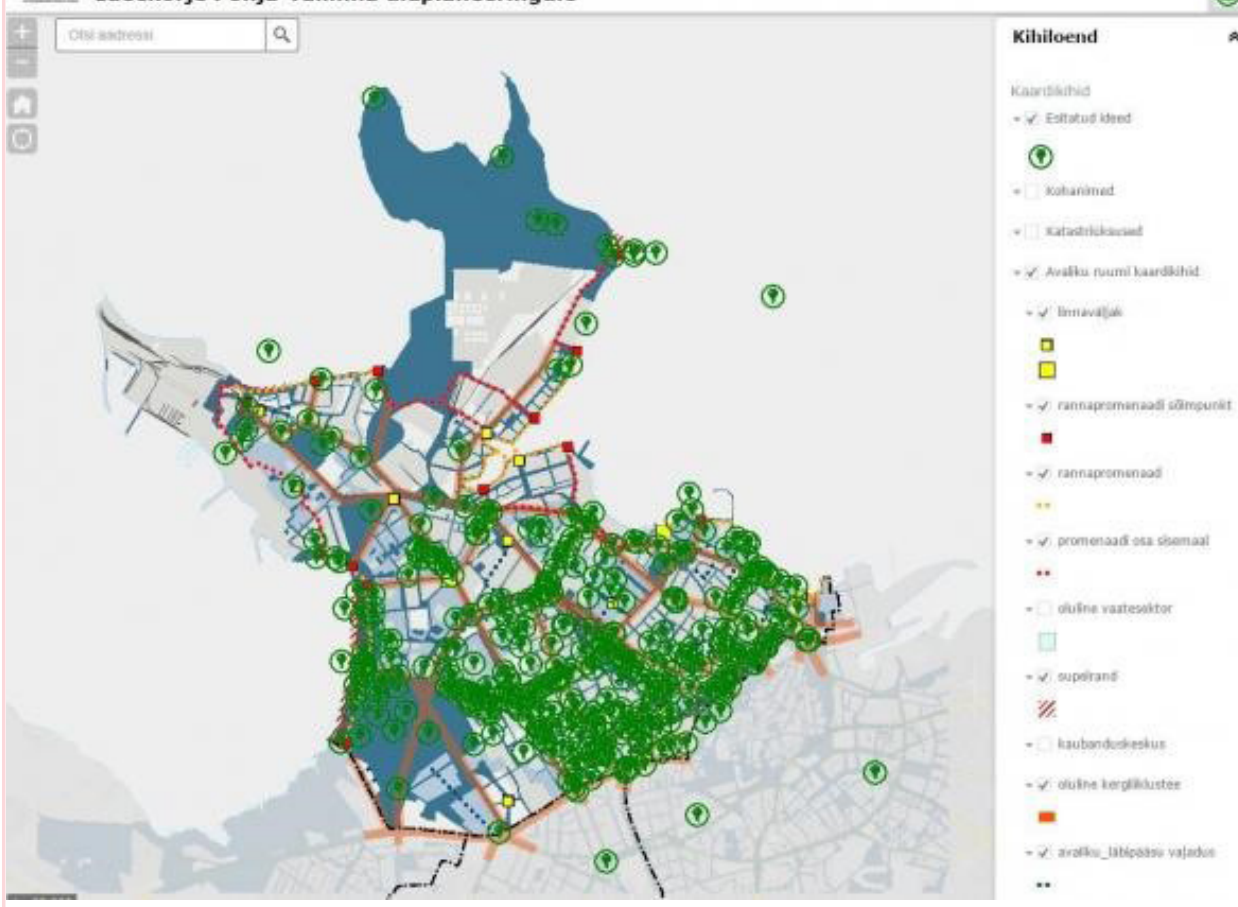

Figure 10. Online GIS map for idea gathering. Source: www.balticurbanlab.eu

Participant selection

\section{Connection to} decisions over the pilot site

\section{Self-reflection from the city}

Information was spread through Facebook pages, mailing lists, press releases and TV. Most users were aged 30-40. A little more than 400 comments were left in total.

Enabled members of the public to leave proposals and express preferences on the general plan within which the pilot site is located.

A surprisingly large group of people are interested in urban planning and willing to give input to the planning process. The method is therefore desirable and useful in urban planning practice, and will be used in other projects.

- Idea gathering through the GIS map is good way of enabling the general public to insert their ideas and opinions.

- The big interest shows that it is worth consulting this active group in the early stage of planning.

- Providing simple instructions to users proved challenging. 


\begin{tabular}{|c|c|c|c|c|c|c|c|c|c|c|}
\hline \multicolumn{3}{|c|}{ Analysis } & \multicolumn{8}{|c|}{$\begin{array}{l}\text { The idea gathering was a way for the city organisation to test how GIS can be } \\
\text { used to collect input from citizens. Anyone could participate, and no specific } \\
\text { target group was reached out to, resulting in a narrow age span among users. } \\
\text { Its influence on decision-making or executive power regarding the content of } \\
\text { the plan for the Skoone Bastion area was limited to advice and consultation. } \\
\text { The activity could be seen as a form of synergy - planners received input about } \\
\text { the development of a new tool, and also about the content of the plan for the } \\
\text { Skoone Bastion area. If more information than age were collected about the } \\
\text { users, planners could get a better understanding about who leaves comments, } \\
\text { which would make it possible to identify any large groups of people who were not } \\
\text { reached. }\end{array}$} \\
\hline \multicolumn{11}{|c|}{ Who participates? } \\
\hline $\begin{array}{l}\text { Diffuse } \\
\text { public } \\
\text { sphere }\end{array}$ & \multicolumn{2}{|c|}{$\begin{array}{l}\text { Open, } \\
\text { self- } \\
\text { selected }\end{array}$} & $\begin{array}{l}\text { Open, with } \\
\text { targeted } \\
\text { recruitment }\end{array}$ & \multicolumn{2}{|c|}{$\begin{array}{l}\text { Randomly } \\
\text { selected }\end{array}$} & \multicolumn{2}{|c|}{$\begin{array}{l}\text { Lay } \\
\text { stake- } \\
\text { holders }\end{array}$} & $\begin{array}{l}\text { Professional } \\
\text { stakeholders }\end{array}$ & $\begin{array}{l}\text { Elected } \\
\text { representatives }\end{array}$ & $\begin{array}{l}\text { Expert } \\
\text { administrators }\end{array}$ \\
\hline \multicolumn{11}{|c|}{ How do participants communicate and take decisions? } \\
\hline \multicolumn{2}{|c|}{$\begin{array}{l}\text { Listen as } \\
\text { spectators }\end{array}$} & \multicolumn{2}{|c|}{$\begin{array}{l}\text { Express } \\
\text { preferences }\end{array}$} & \multicolumn{3}{|c|}{$\begin{array}{l}\text { Develop } \\
\text { preferences }\end{array}$} & \multicolumn{2}{|c|}{ Deliberate } & Bargain & $\begin{array}{l}\text { Deploy } \\
\text { technique and } \\
\text { expertise }\end{array}$ \\
\hline \multicolumn{11}{|c|}{ What influence do participants have over the public decisions and actions? } \\
\hline \multicolumn{3}{|c|}{$\begin{array}{l}\text { Individual } \\
\text { education }\end{array}$} & \multicolumn{2}{|c|}{$\begin{array}{l}\text { Communicative } \\
\text { influence }\end{array}$} & \multicolumn{3}{|c|}{$\begin{array}{l}\text { Advice and } \\
\text { consultation }\end{array}$} & \multicolumn{2}{|c|}{ Co-govern } & Direct authority \\
\hline
\end{tabular}

\section{Workshop on terms of reference for AvaLinn, September 2016}

\begin{tabular}{|l|l|}
\hline About the activity & $\begin{array}{l}\text { The purpose of the workshop was to get more detailed input than the Tallinn } \\
\text { Planning Register survey on how the mobile phone app AvaLinn should work, and } \\
\text { how to attract users. The session began with presentations, a walking tour of the } \\
\text { pilot site and a workshop with different stakeholders. The workshop consisted of } \\
\text { the following activities: collecting ideas for technological solutions; brainstorming } \\
\text { how to communicate change in the urban space and the opportunities presented } \\
\text { by the app; selecting the three best ideas; and applying the ideas to a real-life } \\
\text { situation in the Skoone Bastion area. Finally, all participants discussed the ideas } \\
\text { and proposed solutions. } \\
\text { Each group put forward ideas on how the app could be used for the planning } \\
\text { process of the pilot site. Participants identified crucial points for the success of } \\
\text { the app - the need for a critical mass of users, user-friendliness and the option to } \\
\text { receive location- and user profile-based notifications. The input from the workshop } \\
\text { functioned as the basis for the terms of reference for procuring the technical } \\
\text { solution for the app. }\end{array}$ \\
\hline $\begin{array}{l}\text { Participant } \\
\text { selection }\end{array}$ & $\begin{array}{l}\text { The workshop sought to involve different user groups and invited } 52 \text { professional } \\
\text { stakeholders by e-mail and telephone. Out of these, } 26 \text { persons participated. }\end{array}$ \\
\hline $\begin{array}{l}\text { Among them were landowners, officials, entrepreneurs and software developers. } \\
\text { decisions over the } \\
\text { pilot site }\end{array}$ & $\begin{array}{l}\text { The workshop generated input that the local project group considered valuable } \\
\text { for proceeding with the development and communication of the app. It was not } \\
\text { connected to the content of the plan for the area. }\end{array}$ \\
\hline
\end{tabular}




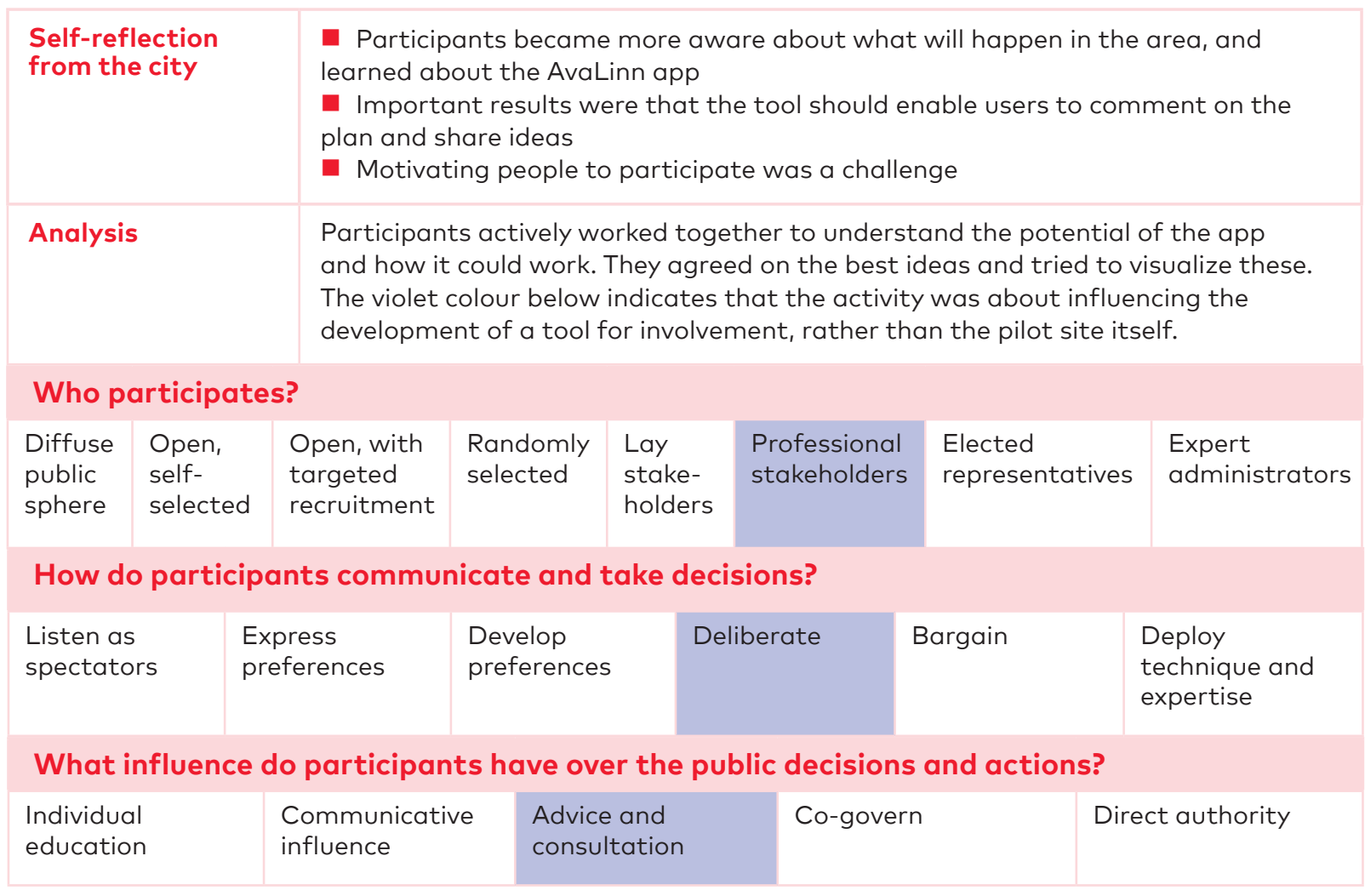

\section{3-day workshop with students and other stakeholders, September 2016}

\begin{tabular}{|l|l}
\hline $\begin{array}{l}\text { About the activity } \\
\text { and to involve urban planning students from Tallinn University and architecture } \\
\text { students from Estonian Academy of Arts in the project. }\end{array}$ \\
$\begin{array}{l}\text { During the first day, the pilot site was presented from the perspective of developer } \\
\text { and businesses; public functions (transport hub); and heritage protection. } \\
\text { Participants also went on a site visit. On the second day, students worked on } \\
\text { visions for the site, which were assessed by a jury on the third day. The visions } \\
\text { provided direct input into the planners' work. The event was organised together } \\
\text { with associated partner Tallinn University. }\end{array}$ \\
$\begin{array}{l}\text { A few months later, students got feedback on the progress of the project, in the } \\
\text { form of presentations of their vision for the site as further developed by the city } \\
\text { organisation. The students were invited to share their opinions. }\end{array}$ \\
$\begin{array}{l}\text { Participant } \\
\text { selection }\end{array}$ & $\begin{array}{l}25 \text { students participated, along with landowners, developers, the Harju county } \\
\text { public transport organiser, and city district representatives. Participants from the } \\
\text { NGO sector were the Pedestrian Union, Urban Lab and Old Town NGO. Public } \\
\text { invitations were made through social media, e-mail lists and press release. In } \\
\text { addition, e-mail invitations were sent to stakeholders in the project. }\end{array}$ \\
\hline $\begin{array}{l}\text { Connection to } \\
\text { pilot site }\end{array}$ & $\begin{array}{l}\text { The students' visions constituted direct input and inspiration to the structural plan } \\
\text { for the pilot site. }\end{array}$ \\
\hline
\end{tabular}




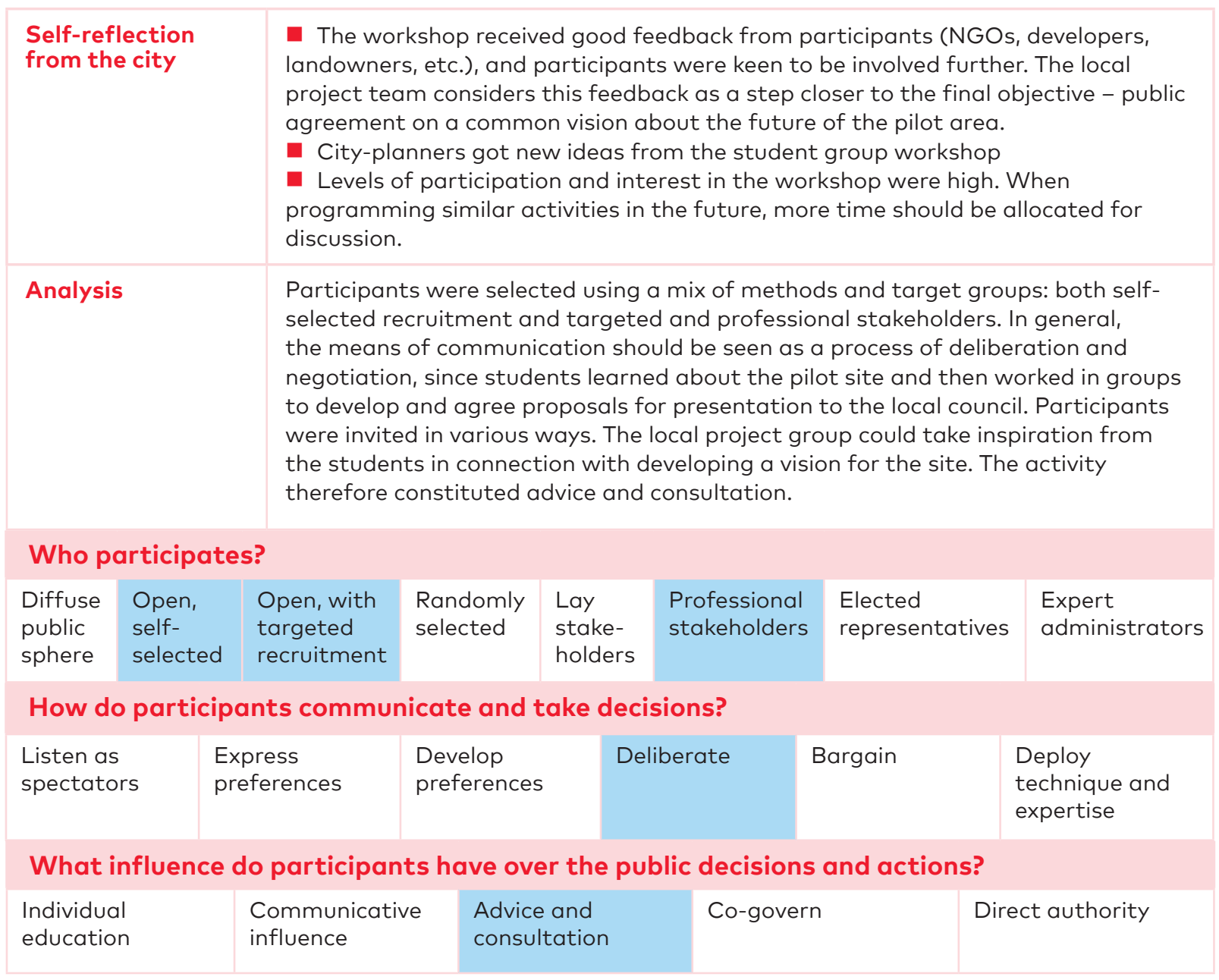

\section{Presentation of draft version of plan for pilot site, February 2017}

\begin{tabular}{l|l} 
About the activity & $\begin{array}{l}\text { The urban planning department organised a three-hour meeting to present the } \\
\text { first draft of the development plan to stakeholders and students. This was a } \\
\text { way of giving feedback to students on the three-day workshop, including giving } \\
\text { students the chance to see which ideas the local project group had included, and } \\
\text { which they had omitted. The development plan was drafted by the city-planners at } \\
\text { Tallinn Chief Architect Office. When designing the plan, the planners kept in mind } \\
\text { the input and ideas gathered during 2016, and integrated these into the pilot area } \\
\text { development plan. The workshop structure consisted of presentations followed by } \\
\text { questions and discussions. Students from Tallinn University then presented their } \\
\text { ongoing work on the pilot site. } \\
\text { City-planners integrated some of the ideas into the structural plan. Some requests } \\
\text { came from developers to increase pedestrian friendliness, while also reducing } \\
\text { accessibility to car traffic. }\end{array}$
\end{tabular}

13 Student presentations are available at: http://www.tallinn.ee/est/baltic-urban-lab/Skoone-ActivityBelt-2.-tootuba-17.-veebruar-2017. 


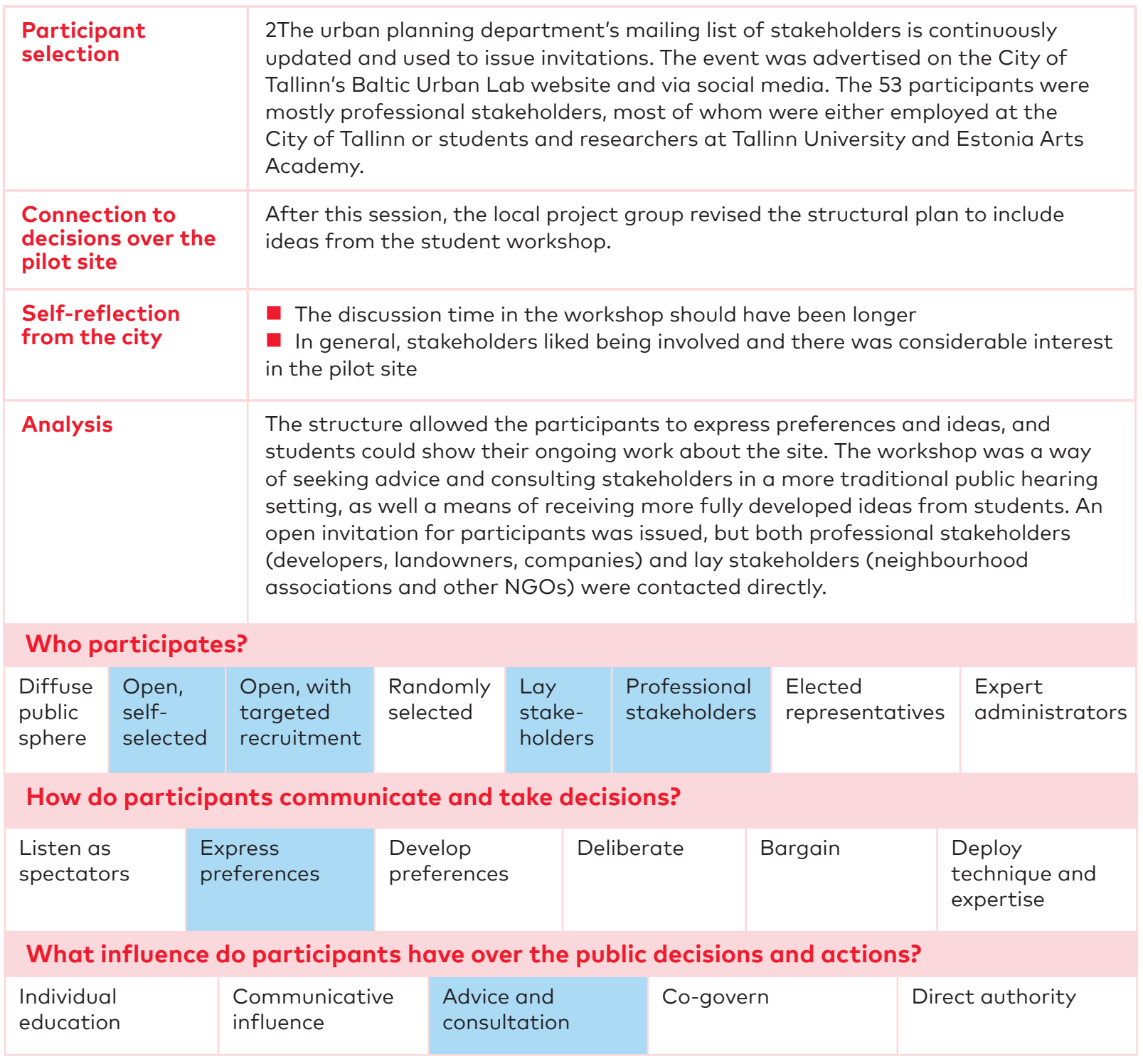




\section{AvaLinn app in use, January 2018-}

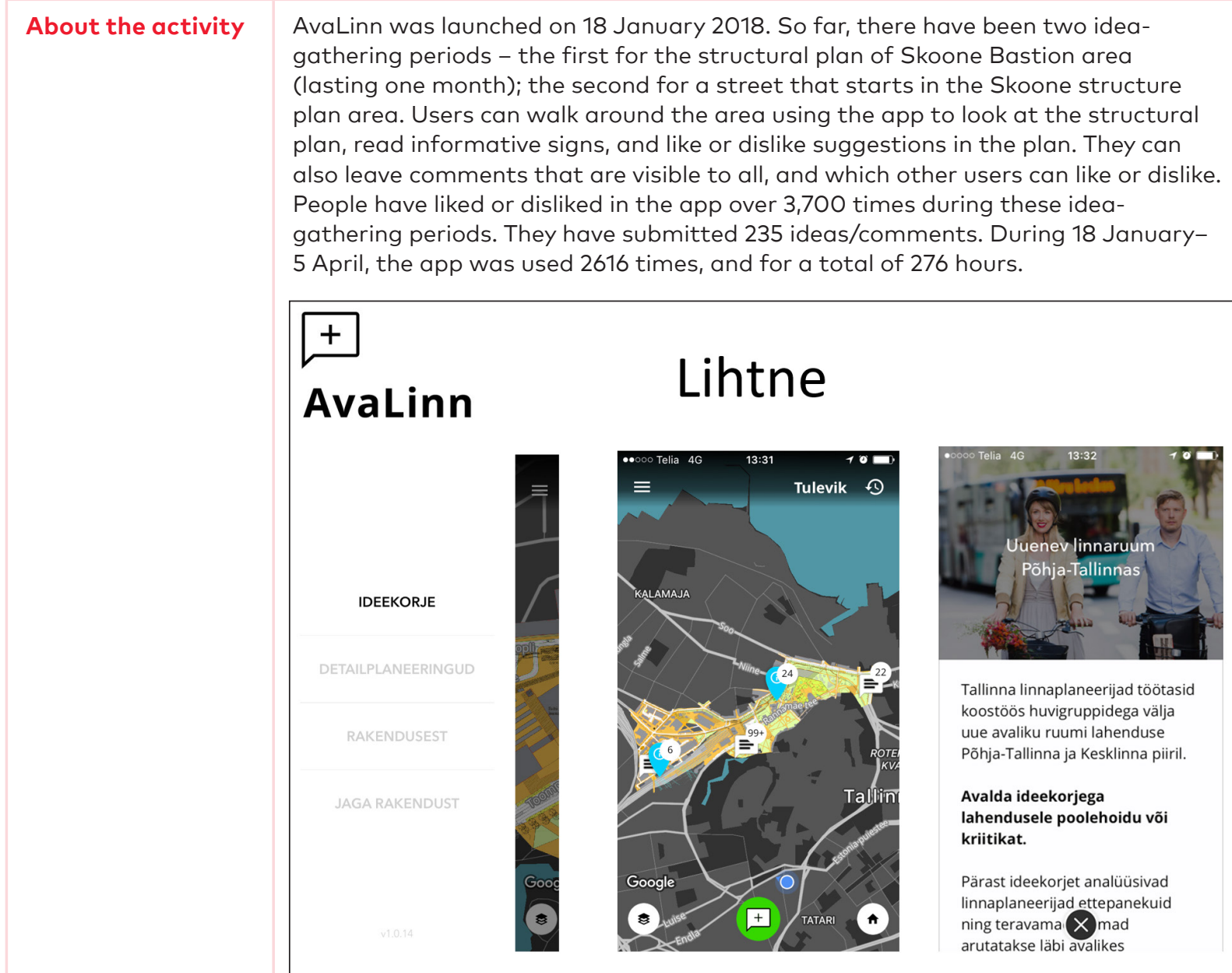

Figure 11. Illustration of the AvaLinn app. Source: Tallinn Urban Planning Department.

\section{Participant selection}

\section{Connection to decisions over the pilot site}

\section{Self-reflection from the city}

Signs marketing the app were put up in the pilot area. Local media was used to promote the app, along with social media (Facebook and Instagram). E-mails were sent directly to stakeholders in the area.

Users can use the app to like or dislike suggestions in the structural plan, and to leave comments.

- Some users wanted a website instead of a mobile app

- Android and IOS versions were used equally

- Usability, user experience, testing and visual interface are very important

- Marketing is very important, but more resources are needed to help people find the app

- The budget limits the comprehensiveness of the app

- Users gave constructive - and more positive than negative - feedback on the structural plans

- Input was provided into the functionality that must be included in the app before the next idea-gathering period

- For larger scale engagement, a parallel web-based solution is needed. 


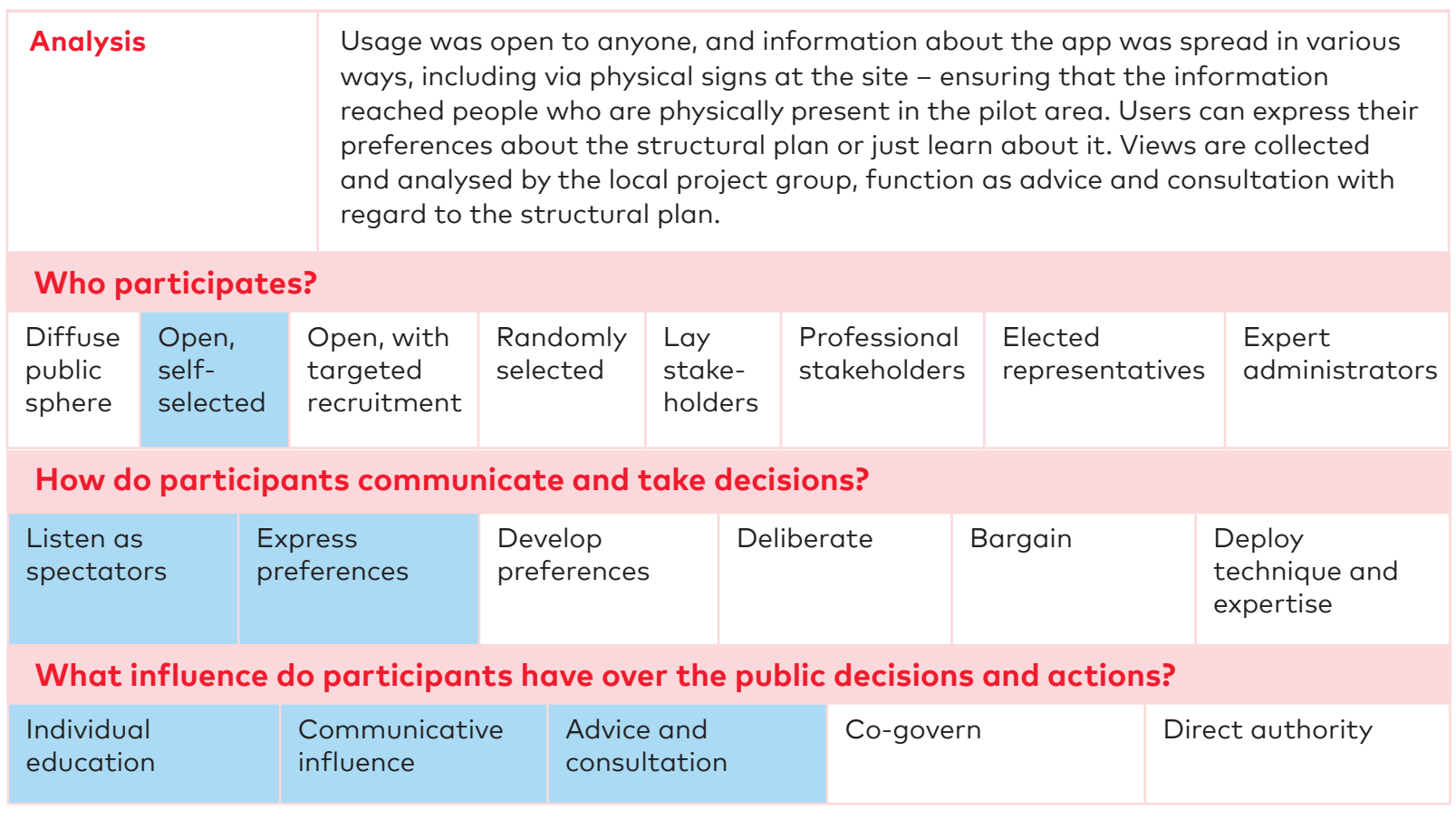

\section{Attempt to set up temporary community gardening, 2017}

\begin{tabular}{|l|l|l|l|l}
\hline About the activity & $\begin{array}{l}\text { A group of people presented the idea of creating a community garden in the } \\
\text { pilot site to the local project group. The initiators had skills based on previous } \\
\text { experience with community gardening abroad, as well as academic knowledge of } \\
\text { landscape architecture. }\end{array}$ \\
& $\begin{array}{l}\text { Meetings were held with city officials from the Environment Department, } \\
\text { Heritage Protection Department and Urban Planning Department. Preliminary } \\
\text { agreement was reached and the community garden began to take shape - first, } \\
\text { a limestone keyhole flowerbed and a small window frame greenhouse were built. } \\
\text { As the garden was in a UNESCO heritage protection site, it sparked debate, and } \\
\text { ultimately the Heritage Protection Department cancelled the project. }\end{array}$ \\
\hline $\begin{array}{l}\text { Participant } \\
\text { selection }\end{array}$ & $\begin{array}{l}\text { The urban gardening team presented the idea to the city organisation. } \\
\text { Connection to } \\
\text { decisions over the } \\
\text { pilot site }\end{array}$ & $\begin{array}{l}\text { Temporary activities at a development site can be used to activate vacant spaces, } \\
\text { increasing the likelihood that a permanent use will eventually be found for such } \\
\text { spaces. }\end{array}$ \\
\hline $\begin{array}{l}\text { Self-reflection } \\
\text { from the city }\end{array}$ & $\begin{array}{l}\text { The attempt was halted, but the initiative still had positive outcomes } \\
\text { City officials became more aware of temporary uses and gardening }\end{array}$ \\
\hline $\begin{array}{l}\text { The initiators organised many meetings for the community and established } \\
\text { a network of community gardeners across the city. New community gardening } \\
\text { projects were started in other city districts. The collaboration also continues with } \\
\text { the Environment Department, and a new community garden will soon be created } \\
\text { in Tallinn. }\end{array}$
\end{tabular}

\begin{tabular}{l|l} 
Analysis & A local association took the initiative. It is difficult to say which modes of
\end{tabular} communication were ongoing in this case, as several forms were employed. Participants have in some way co-governed the temporary gardening activity, since they were organising among themselves and were responsible for material and creating the gardens. Ultimately, it is clear that the Heritage Protection Department made the final decision. 


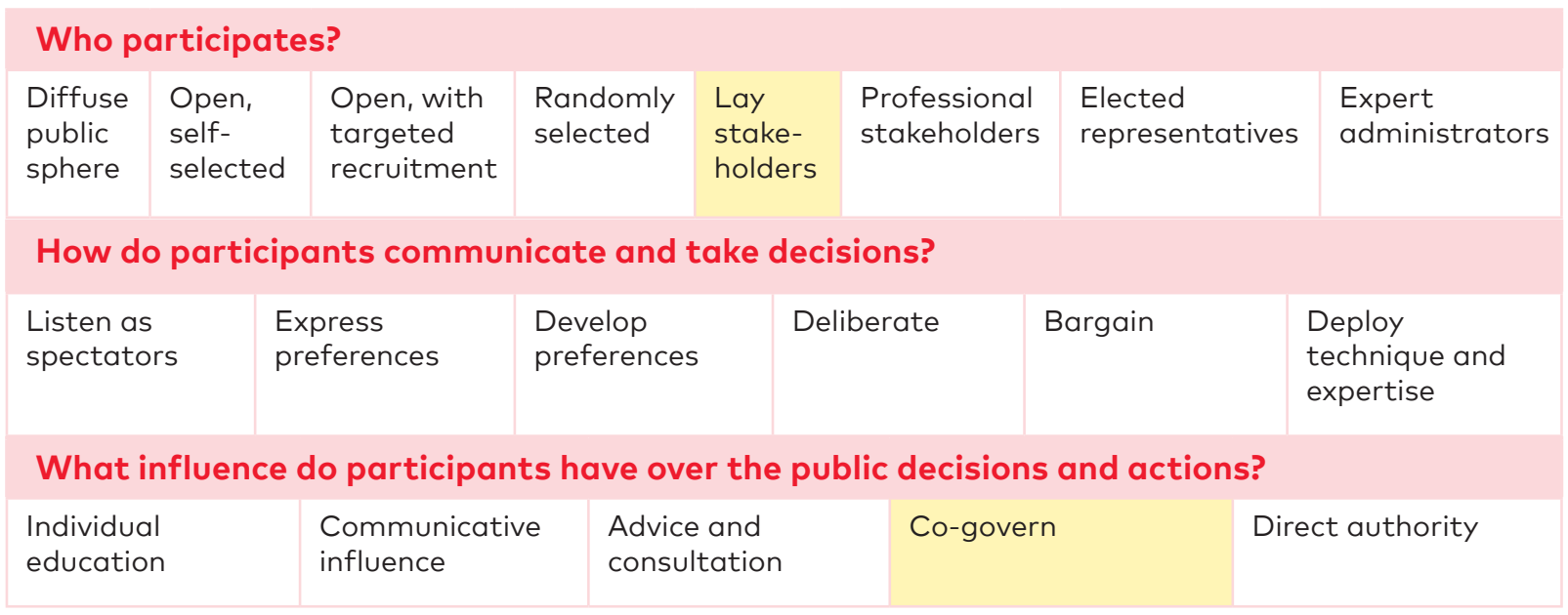

\section{Summary}

Four out of seven activities have been about using or developing digital platforms for participation or communication. In Skoone Bastion area, three types of engagement activities were used - activities that aim to activate the pilot site while planning is ongoing; activities that influence the pilot site; and activities that influence tools for participation. The temporary gardening initiative was a way of activating the site and making it accessible to the public while the planning work is still ongoing. The test of the Tallinn Planning Register and the workshop on terms of reference for AvaLinn were about inviting the public and relevant professionals to participate in the process of designing the app, in order to make it as accessible and useful as possible. The first was an open format, in which users could express preferences. The second involved professional stakeholders who had a more deliberate process for developing the tool. The remaining four activities were about gathering input into and developing the plan for the Skoone Bastion area.

The local project group dedicated several days to a collaborative (and almost deliberative) process involving Tallinn University and the Estonian Academy of Arts. This involved students elaborating upon visions and later presenting the work, which fed into a parallel process of drafting the plan for the site.

With the exception of the temporary garden- ing, all activities were about the participants acting as advisers to the formal decision-makers. However, the use of the AvaLinn app could, of course, also teach participants about the planning site without requiring them to express opinions about it. Since the app operates in an "uncontrolled" space, it becomes a part of the public sphere, where discussions are ongoing and messages might reach the local project group (thereby having a communicative influence on the decision-makers).

Most of the activities have been open to any interested participants. The exceptions are the temporary gardening (which was initiated by an association) and the workshop (to which participants were personally invited).

\subsection{Itäharju-Kupittaa, Turku, Finland}

The Itäharju-Kupittaa pilot site is part of a larger redevelopment project encompassing the university campus and science park area. During Baltic Urban Lab, the local project group has been a key actor in organising a series of meetings at which key stakeholders have discussed how to develop the Itäharju area. During this process, many different methods and activities have been tried out. This process has fed in to the masterplan for the area. Sometimes the word "vision" is used in connection with the activities. However, both "vision" and "masterplan" refer to the same strategic planning document that outlines Itäharju-Kupittaa development up to 2050. 


\begin{tabular}{|c|c|c|c|c|c|c|c|c|c|}
\hline \multicolumn{10}{|c|}{ Innovating the future of Kupittaa, May 2016} \\
\hline \multicolumn{3}{|c|}{ About the activity } & \multicolumn{7}{|c|}{$\begin{array}{l}\text { Prior to the meeting, the local project group had mapped the interests of key } \\
\text { actors. During the meeting, seven main themes for the development were } \\
\text { identified and agreed on: smooth mobility; best encounters; well connected; } \\
\text { Kupittaa all night long; Kupittaa all year around; smart solutions for smart people; } \\
\text { and state-of-the-art hub for international encounters. There were separate } \\
\text { discussions concerning the campus and science park area, and how the pilot site } \\
\text { Itäharju can be rebuilt in connection with the spearhead projects. }\end{array}$} \\
\hline \multicolumn{3}{|c|}{$\begin{array}{l}\text { Participant } \\
\text { selection }\end{array}$} & \multicolumn{7}{|c|}{$\begin{array}{l}\text { Invitations were sent by email to key representatives at the University of Turku, } \\
\text { Åbo Akademi University, Turku University of Applied Sciences, Turku Technology } \\
\text { Properties Ltd, Turku Science Park Ltd and University properties of Finland Ltd. }\end{array}$} \\
\hline \multicolumn{3}{|c|}{$\begin{array}{l}\text { Connection to } \\
\text { decisions over the } \\
\text { pilot site }\end{array}$} & \multicolumn{7}{|c|}{$\begin{array}{l}\text { The discussions related both to the campus and science park in Kupittaa (a } \\
\text { spearhead project next to the pilot site area), and to Itäharju. }\end{array}$} \\
\hline \multicolumn{3}{|c|}{$\begin{array}{l}\text { Self-reflection } \\
\text { from the city }\end{array}$} & \multicolumn{7}{|c|}{ - Central actors were missing } \\
\hline \multicolumn{3}{|c|}{ Analysis } & \multicolumn{7}{|c|}{$\begin{array}{l}\text { Professional stakeholders with interests in the site participated. Common aims } \\
\text { were agreed on at the meeting, which meant the communication served to at } \\
\text { least develop preferences. However, in some ways, it also constituted deliberation, } \\
\text { as this step encompasses reaching agreement. Agreeing on common aims also } \\
\text { counts as developing strategies together, which qualifies the event as co-govern. }\end{array}$} \\
\hline \multicolumn{10}{|c|}{ Who participates? } \\
\hline $\begin{array}{l}\text { Diffuse } \\
\text { public } \\
\text { sphere }\end{array}$ & \multicolumn{2}{|c|}{$\begin{array}{l}\text { Open, } \\
\text { self- } \\
\text { selected }\end{array}$} & $\begin{array}{l}\text { Open, with } \\
\text { targeted } \\
\text { recruitment }\end{array}$ & & $\begin{array}{l}\text { domly } \\
\text { cted }\end{array}$ & $\begin{array}{l}\text { Lay } \\
\text { stake- } \\
\text { holders }\end{array}$ & $\begin{array}{l}\text { Professional } \\
\text { stakeholders }\end{array}$ & $\begin{array}{l}\text { Elected } \\
\text { representatives }\end{array}$ & $\begin{array}{l}\text { Expert } \\
\text { administrators }\end{array}$ \\
\hline \multicolumn{10}{|c|}{ How do participants communicate and take decisions? } \\
\hline \multicolumn{2}{|c|}{$\begin{array}{l}\text { Listen as } \\
\text { spectators }\end{array}$} & \multicolumn{2}{|c|}{$\begin{array}{l}\text { Express } \\
\text { preferences }\end{array}$} & \multicolumn{3}{|c|}{$\begin{array}{l}\text { Develop } \\
\text { preferences }\end{array}$} & berate & Bargain & $\begin{array}{l}\text { Deploy } \\
\text { technique and } \\
\text { expertise }\end{array}$ \\
\hline \multicolumn{10}{|c|}{ What influence do participants have over the public decisions and actions? } \\
\hline \multicolumn{3}{|c|}{$\begin{array}{l}\text { Individual } \\
\text { education }\end{array}$} & \multicolumn{2}{|c|}{$\begin{array}{l}\text { Communicative } \\
\text { influence }\end{array}$} & \multicolumn{2}{|c|}{$\begin{array}{l}\text { Advice and } \\
\text { consultation }\end{array}$} & Co-govern & & Direct authority \\
\hline
\end{tabular}




\section{Open Call, June 2016}

\begin{tabular}{|c|c|}
\hline About the activity & $\begin{array}{l}\text { The Open Call event was a follow-up meeting to Innovating the future of Kupittaa } \\
\text { and was used to further discuss the seven main themes for development. An } \\
\text { external consultant was brought in to help plan and facilitate the event. The } \\
\text { themes were discussed in workshops facilitated by city experts. The event marked } \\
\text { the beginning of the planning process for the city's campus area and Science Park } \\
\text { in Kupittaa. Key actors discussed and brainstormed the future of the campus and } \\
\text { Science Park in Kupittaa, next to the pilot site Itäharju. There were also discussions } \\
\text { about how the pilot site can be rebuilt, and how it relates to other spearhead } \\
\text { projects in the city. }\end{array}$ \\
\hline \multirow{6}{*}{$\begin{array}{l}\text { Participant } \\
\text { selection }\end{array}$} & All participants were invited by email. The response was as follows: \\
\hline & Invitations sent (approx.) \\
\hline & $\begin{array}{l}\text { The city and other } \\
\text { public actors }\end{array}$ \\
\hline & Owners and tenants \\
\hline & $\begin{array}{l}\text { Entrepreneurs and } \\
\text { companies }\end{array}$ \\
\hline & Other key actors \\
\hline $\begin{array}{l}\text { Connection to } \\
\text { decisions over the } \\
\text { pilot site }\end{array}$ & $\begin{array}{l}\text { The discussions and planning process was related to the campus and science park } \\
\text { in Kupittaa, a spearhead project next to the pilot site area. }\end{array}$ \\
\hline $\begin{array}{l}\text { Self-reflection } \\
\text { from the city }\end{array}$ & $\begin{array}{l}\text { This was the first time this kind of vision work was done } \\
\text { The meeting discussed a vision alongside the main themes } \\
\text { It is important to see what can be outsourced to consultants and facilitators, } \\
\text { and what needs to be done by personnel from the city } \\
\text { However, it would be wise to procure workshop facilitation from an external } \\
\text { consultant, since it reduces the level of conflict between local authority experts } \\
\text { and participants } \\
\text { The event was successful, as it led to intensive discussions and generated good } \\
\text { outcomes for the next stage } \\
\text { The event received positive media attention } \\
\text { Continued collaboration with the external facilitator was unfortunately not } \\
\text { possible due to challenges associated with public procurement law. }\end{array}$ \\
\hline Analysis & $\begin{array}{l}\text { Professional stakeholders were invited. Open discussions made it possible for } \\
\text { participants to develop their thoughts. This is a form of advisory forum to develop } \\
\text { the spearhead project area. }\end{array}$ \\
\hline
\end{tabular}

\section{Who participates?}

\begin{tabular}{l|l|l|l|l|l|l|l|}
$\begin{array}{l}\text { Diffuse } \\
\text { public } \\
\text { sphere }\end{array}$ & $\begin{array}{l}\text { Open, } \\
\text { self- } \\
\text { selected }\end{array}$ & $\begin{array}{l}\text { Open, with } \\
\text { targeted } \\
\text { recruitment }\end{array}$ & $\begin{array}{l}\text { Randomly } \\
\text { selected }\end{array}$ & $\begin{array}{l}\text { Lay } \\
\text { stake- } \\
\text { holders }\end{array}$ & $\begin{array}{l}\text { Professional } \\
\text { stakeholders }\end{array}$ & $\begin{array}{l}\text { Elected } \\
\text { representatives }\end{array}$ & $\begin{array}{l}\text { Expert } \\
\text { administrators }\end{array}$ \\
\end{tabular}

\section{How do participants communicate and take decisions?

\begin{tabular}{|c|c|c|c|c|c|}
\hline $\begin{array}{l}\text { Listen as } \\
\text { spectators }\end{array}$ & $\begin{array}{l}\text { Express } \\
\text { preferences }\end{array}$ & $\begin{array}{l}\text { Develop } \\
\text { preferences }\end{array}$ & Deliberate & Bargain & $\begin{array}{l}\text { Deploy } \\
\text { technique and } \\
\text { expertise }\end{array}$ \\
\hline
\end{tabular}

\section{What influence do participants have over the public decisions and actions?}

\begin{tabular}{|c|c|c|c|c|}
\hline $\begin{array}{l}\text { Individual } \\
\text { education }\end{array}$ & $\begin{array}{l}\text { Communicative } \\
\text { influence }\end{array}$ & $\begin{array}{l}\text { Advice and } \\
\text { consultation }\end{array}$ & Co-govern & Direct authority \\
\hline
\end{tabular}




\section{Turku Future Forum, four-day event, November-December 2016}

About the activity The purpose was to get an understanding of different stakeholder groups' needs concerning future development, but also to create a sense of joint effort amongst all important actors in the area, and to collect local residents' views ideas about regional development. The event included keynote speeches, panel discussions, different participatory methods (world café, future wheel) and group discussions. The future wheel is a means of asking basic questions in development work (What do we want to achieve? What are the biggest opportunities and risks?). There was also an idea contest, in which students and university personnel were invited to propose new solutions to develop the Campus and Science Park area in Kupittaa. A range of experts from the city organisation took part in planning and organising the seminars/workshops. People from the university were involved and a PR agency helped with the communication.

Each day covered one specific topic: 1 ) attractive urban environment; 2) smart mobility; 3) smart actors, smart solutions; and 4) international meeting point (the idea contest)

Many ideas were collected on how to boost interaction and innovation processes, as well as general cooperation in the campus and science park area. A significant number of the ideas proposed related to the development of the physical environment, not least traffic and transport.

\section{Participant} selection
The first two events were open to the public, while the third was directed to companies and development organisations in the Campus and Science Park area. The fourth was aimed at students and university personnel. There were between 40 to 60 participants each day.

\section{Connection to decisions over the pilot site}

Self-reflection from the city
The ideas gathered have been processed into five main thematic areas for development and will feed into the process of developing a common vision for the area.

- The number of participants was sufficient, and the amount and quality of ideas gathered were surprising

- One concern was how to reach the "right people", which in this context meant those who would not usually be active in these kinds of meetings

- Those who participated were mostly very active and the discussions were fruitful

- These methods of involving people in brainstorming proved to be effective. The events' informal atmosphere made it easy for people to participate in the discussions.

- The future wheel proved to be a good method of getting people to think differently

- It was a good way to involve both external stakeholders and different parts of the city organisation in the planning process

- The contents of the events need to be relevant/appealing for stakeholders, and the invitations need to be sent well in advance

- It is challenging to arrange events like this when competing events are taking place at the same time.

Analysis

Several methods of recruiting participants were employed, e.g. open invitations to the public, and direct contact with professional stakeholders. The event itself employed various different methods of engagement - participants could gain information, express their views and develop their thoughts. The outcomes inform the development of the vision, classifying the level of influence as advice and consultation. 


\begin{tabular}{|c|c|c|c|c|c|c|c|}
\hline \multicolumn{8}{|c|}{ Who participates? } \\
\hline $\begin{array}{l}\text { Diffuse } \\
\text { public } \\
\text { sphere }\end{array}$ & $\begin{array}{l}\text { Open, } \\
\text { self- } \\
\text { selected }\end{array}$ & $\begin{array}{l}\text { Open, with } \\
\text { targeted } \\
\text { recruitment }\end{array}$ & $\begin{array}{l}\text { Randomly } \\
\text { selected }\end{array}$ & $\begin{array}{l}\text { Lay } \\
\text { stake- } \\
\text { holders }\end{array}$ & $\begin{array}{l}\text { Professional } \\
\text { stakeholders }\end{array}$ & $\begin{array}{l}\text { Elected } \\
\text { representatives }\end{array}$ & $\begin{array}{l}\text { Expert } \\
\text { administrators }\end{array}$ \\
\hline \multicolumn{8}{|c|}{ How do participants communicate and take decisions? } \\
\hline \multicolumn{2}{|c|}{$\begin{array}{l}\text { Listen as } \\
\text { spectators }\end{array}$} & $\begin{array}{l}\text { Express } \\
\text { oreferences }\end{array}$ & \multicolumn{2}{|c|}{$\begin{array}{l}\text { Develop } \\
\text { preferences }\end{array}$} & Deliberate & Bargain & $\begin{array}{l}\text { Deploy } \\
\text { technique and } \\
\text { expertise }\end{array}$ \\
\hline \multicolumn{8}{|c|}{ What influence do participants have over the public decisions and actions? } \\
\hline \multicolumn{2}{|c|}{$\begin{array}{l}\text { Individual } \\
\text { education }\end{array}$} & $\begin{array}{l}\text { Communicative } \\
\text { influence }\end{array}$ & \multicolumn{2}{|c|}{$\begin{array}{l}\text { Advice and } \\
\text { consultation }\end{array}$} & \multicolumn{2}{|l|}{ Co-govern } & Direct authority \\
\hline
\end{tabular}

\section{Initial forum for the landowners and leaseholders, April 2017}

\begin{tabular}{|c|c|}
\hline About the activity & $\begin{array}{l}\text { The objective was to discuss the current state and further development of the } \\
\text { pilot site with existing landowners. City of Turku organised the event, which began } \\
\text { with an introductory lecture followed by discussions. The meeting initiated the } \\
\text { stakeholder dialogue. Among the issues addressed were mapping the interests of } \\
\text { some of the actors, discussing common goals, receiving input to the scheduling } \\
\text { process, forging connections between different actors and landowners, clarifying } \\
\text { expectations regarding the plans for the area, and collaboration on handling } \\
\text { contaminated land. It was agreed that smaller discussion forums would be held } \\
\text { continuously. }\end{array}$ \\
\hline $\begin{array}{l}\text { Participant } \\
\text { selection }\end{array}$ & $\begin{array}{l}\text { About } 65 \text { landowners were invited from a contact list sourced from the Land } \\
\text { Ownership Registry and Leasehold Registry. }\end{array}$ \\
\hline $\begin{array}{l}\text { Connection to } \\
\text { decisions over the } \\
\text { pilot site }\end{array}$ & $\begin{array}{l}\text { The meeting was the first step in the process of handling the planning of the pilot } \\
\text { site in cooperation with the stakeholders. }\end{array}$ \\
\hline $\begin{array}{l}\text { Self-reflection } \\
\text { from the city }\end{array}$ & $\begin{array}{l}\text { The content had not previously been discussed at a forum on this scale, and the } \\
\text { atmosphere was positive and open } \\
\text { Good input was received for continuing the planning process } \\
\text { The event provided important impetus for future partnerships } \\
\text { The city stressed that open dialogue proved necessary, as the majority } \\
\text { expressed a will to develop the area further. }\end{array}$ \\
\hline Analysis & $\begin{array}{l}\text { Professional stakeholders (in this case, landowners) were recruited directly. } \\
\text { The meeting structure shows signs of express preferences. The city of Turku } \\
\text { established a meeting in which they could gather advice and consultation. }\end{array}$ \\
\hline
\end{tabular}




\begin{tabular}{|c|c|c|c|c|c|c|c|c|c|}
\hline \multicolumn{10}{|c|}{ Who participates? } \\
\hline $\begin{array}{l}\text { Diffuse } \\
\text { public } \\
\text { sphere }\end{array}$ & \multicolumn{2}{|c|}{$\begin{array}{l}\text { Open, } \\
\text { self- } \\
\text { selected }\end{array}$} & $\begin{array}{l}\text { Open, with } \\
\text { targeted } \\
\text { recruitment }\end{array}$ & \multicolumn{2}{|c|}{$\begin{array}{l}\text { Randomly } \\
\text { selected }\end{array}$} & $\begin{array}{l}\text { Lay } \\
\text { stake- } \\
\text { holders }\end{array}$ & $\begin{array}{l}\text { Professional } \\
\text { stakeholders }\end{array}$ & $\begin{array}{l}\text { Elected } \\
\text { representatives }\end{array}$ & $\begin{array}{l}\text { Expert } \\
\text { administrators }\end{array}$ \\
\hline \multicolumn{10}{|c|}{ How do participants communicate and take decisions? } \\
\hline \multicolumn{3}{|c|}{$\begin{array}{l}\text { Listen as } \\
\text { spectators }\end{array}$} & $\begin{array}{l}\text { Express } \\
\text { preferences }\end{array}$ & \multicolumn{3}{|c|}{$\begin{array}{l}\text { Develop } \\
\text { preferences }\end{array}$} & Deliberate & Bargain & $\begin{array}{l}\text { Deploy } \\
\text { technique and } \\
\text { expertise }\end{array}$ \\
\hline \multicolumn{10}{|c|}{ What influence do participants have over the public decisions and actions? } \\
\hline \multicolumn{3}{|c|}{$\begin{array}{l}\text { Individual } \\
\text { education }\end{array}$} & \multicolumn{2}{|c|}{$\begin{array}{l}\text { Communicative } \\
\text { influence }\end{array}$} & \multicolumn{2}{|c|}{$\begin{array}{l}\text { Advice and } \\
\text { consultation }\end{array}$} & \multicolumn{2}{|l|}{ Co-govern } & Direct authority \\
\hline
\end{tabular}

\section{Workshop for key actors, March 2017}

\begin{tabular}{|c|c|c|c|c|c|c|c|}
\hline \multicolumn{2}{|c|}{ About the activity } & \multicolumn{6}{|c|}{$\begin{array}{l}\text { This workshop clarified and crystallised a common vision for the Campus and } \\
\text { Science Park spearhead project area and developed a number of concrete actions. } \\
\text { The day began with an introduction and review of the current situation. During } \\
\text { joint discussions, main topics of interest were specified. Workshop sessions } \\
\text { involving smaller groups examined thematic perspectives and reviewed actions for } \\
\text { reaching goals. Activities necessary for the future development of the project were } \\
\text { listed. The event was organised by City of Turku and facilitated by an external } \\
\text { expert. }\end{array}$} \\
\hline \multicolumn{2}{|c|}{$\begin{array}{l}\text { Participant } \\
\text { selection }\end{array}$} & \multicolumn{6}{|c|}{$\begin{array}{l}\text { The invited participants were actors who had taken part in past meetings such as: } \\
\text { Åbo Akademi University } \\
\text { City of Turku/representatives from different fields } \\
\text { Teleste Corporation } \\
\text { VSSHP (Hospital District of Southwest Finland) } \\
\text { University of Turku } \\
\text { Turku Science Park Ltd } \\
\text { Turku Technology Properties Ltd } \\
\text { World Trade Center }\end{array}$} \\
\hline \multicolumn{2}{|c|}{$\begin{array}{l}\text { Connection to } \\
\text { decisions over the } \\
\text { pilot site }\end{array}$} & \multicolumn{6}{|c|}{ The results have informed the final version of the vision and to make action plans. } \\
\hline \multicolumn{2}{|c|}{$\begin{array}{l}\text { Self-reflection } \\
\text { from the city }\end{array}$} & \multicolumn{6}{|c|}{$\begin{array}{l}\text { The event gave good input for producing the final materials } \\
\text { The most important factor was common interaction and commitment } \\
\text { Combining the structure and content into a vision is challenging } \\
\text { Finding a common understanding needs time and cooperation. All actors' time } \\
\text { is limited and thus involving them needs good planning }\end{array}$} \\
\hline \multicolumn{2}{|c|}{ Analysis } & \multicolumn{6}{|c|}{$\begin{array}{l}\text { This meeting gathered participants from previous meetings, professional } \\
\text { stakeholders and expert administrators from other public departments. The event } \\
\text { enabled participants to develop their preferences and deploy their expertise. It was } \\
\text { the fourth meeting in a series of events aiming to create a common vision for the } \\
\text { spearhead project area. Since the common vision was crystallized and an action } \\
\text { plan established, the level of influence seems to have been co-govern. }\end{array}$} \\
\hline \multicolumn{8}{|c|}{ Who participates? } \\
\hline $\begin{array}{l}\text { Diffuse } \\
\text { public } \\
\text { sphere }\end{array}$ & $\begin{array}{l}\text { Open, } \\
\text { self- } \\
\text { selected }\end{array}$ & $\begin{array}{l}\text { Open, with } \\
\text { targeted } \\
\text { recruitment }\end{array}$ & $\begin{array}{l}\text { Randomly } \\
\text { selected }\end{array}$ & $\begin{array}{l}\text { Lay } \\
\text { stake- } \\
\text { holders }\end{array}$ & $\begin{array}{l}\text { Professional } \\
\text { stakeholders }\end{array}$ & $\begin{array}{l}\text { Elected } \\
\text { representatives }\end{array}$ & $\begin{array}{l}\text { Expert } \\
\text { administrators }\end{array}$ \\
\hline
\end{tabular}


How do participants communicate and take decisions?

\begin{tabular}{|c|c|c|c|c|c|}
\hline $\begin{array}{l}\text { Listen as } \\
\text { spectators }\end{array}$ & $\begin{array}{l}\text { Express } \\
\text { preferences }\end{array}$ & $\begin{array}{l}\text { Develop } \\
\text { preferences }\end{array}$ & Deliberate & Bargain & $\begin{array}{l}\text { Deploy } \\
\text { technique and } \\
\text { expertise }\end{array}$ \\
\hline
\end{tabular}

\section{What influence do participants have over the public decisions and actions?}

\begin{tabular}{|c|c|c|c|c|}
\hline $\begin{array}{l}\text { Individual } \\
\text { education }\end{array}$ & $\begin{array}{l}\text { Communicative } \\
\text { influence }\end{array}$ & $\begin{array}{l}\text { Advice and } \\
\text { consultation }\end{array}$ & Co-govern & Direct authority \\
\hline
\end{tabular}

\section{Turku Future Hackathon, three-day competition, September-October 2017}

\begin{tabular}{|c|c|}
\hline About the activity & $\begin{array}{l}\text { The aim of this innovation competition was to generate applications for services } \\
\text { that increase the liveliness and attractiveness of the Campus and Science Park } \\
\text { area, as well as ideas for interesting meeting places and for increasing smart } \\
\text { mobility. The competition posed the question How would you or your team } \\
\text { advance services, environments and/or smart mobility to increase the liveliness and } \\
\text { attractiveness of the Campus and Science Park area in Turku? The event brought } \\
\text { together } 16 \text { teams, two of which shared the 8,000-euro prize. The City of Turku, } \\
\text { together with Elisa Oyj, Turku Science Park, and Turku Technology Properties were } \\
\text { organisers. }\end{array}$ \\
\hline $\begin{array}{l}\text { Participant } \\
\text { selection }\end{array}$ & $\begin{array}{l}\text { The participants were students, civil enthusiasts and companies. The City of Turku } \\
\text { conducted a survey with the purpose of gathering knowledge about the marketing } \\
\text { of the event, which showed that the majority of the participants had received } \\
\text { information via friends and social media. }\end{array}$ \\
\hline $\begin{array}{l}\text { Connection to } \\
\text { decisions over the } \\
\text { pilot site }\end{array}$ & $\begin{array}{l}\text { The competition was about developing applications for services in the Campus } \\
\text { and Science Park area. }\end{array}$ \\
\hline $\begin{array}{l}\text { Self-reflection } \\
\text { from the city }\end{array}$ & $\begin{array}{l}\text { The event led to proposals for new and interesting methods, as well as ideas for } \\
\text { developing the activity in and functionality of the area } \\
\text { The winning teams demonstrated a comprehensive approach that took into } \\
\text { consideration the physical, functional and social environment } \\
\text { The city of Turku was pleased by the co-operation between different parties in } \\
\text { the competition. }\end{array}$ \\
\hline Analysis & $\begin{array}{l}\text { Both companies (professional stakeholders) and civilians were recruited through } \\
\text { open, self-selected means. Participants deployed technique and expertise to solve } \\
\text { issues that they were encouraged to address. Participants learned and developed } \\
\text { their skills while taking part in the event. The commission was not about planning } \\
\text { the area itself, but about creating applications for services in the area - as such, it } \\
\text { was more akin to developing tools for future residents. }\end{array}$ \\
\hline
\end{tabular}

\section{Who participates?}

\begin{tabular}{|c|c|c|c|c|c|c|c|}
\hline $\begin{array}{l}\text { Diffuse } \\
\text { public } \\
\text { sphere }\end{array}$ & $\begin{array}{l}\text { Open, } \\
\text { self- } \\
\text { selected }\end{array}$ & $\begin{array}{l}\text { Open, with } \\
\text { targeted } \\
\text { recruitment }\end{array}$ & $\begin{array}{l}\text { Randomly } \\
\text { selected }\end{array}$ & $\begin{array}{l}\text { Lay } \\
\text { stake- } \\
\text { holders }\end{array}$ & $\begin{array}{l}\text { Professional } \\
\text { stakeholders }\end{array}$ & $\begin{array}{l}\text { Elected } \\
\text { representatives }\end{array}$ & $\begin{array}{l}\text { Expert } \\
\text { administrators }\end{array}$ \\
\hline
\end{tabular}

\section{How do participants communicate and take decisions?}

\begin{tabular}{|l|l|l|l|l}
$\begin{array}{l}\text { Listen as } \\
\text { spectators }\end{array}$ & $\begin{array}{l}\text { Express } \\
\text { preferences }\end{array}$ & $\begin{array}{l}\text { Develop } \\
\text { preferences }\end{array}$ & Deliberate & Bargain \\
$\begin{array}{l}\text { Deploy } \\
\text { technique and } \\
\text { expertise }\end{array}$
\end{tabular}


What influence do participants have over the public decisions and actions?

Individual

education

Communicative

Advice and

consultation

Co-govern

Direct authority

\section{Summary}

The local project group has designed a continuous process in which a series of events feed in to the final version of the masterplan for the pilot site and surrounding area. For this reason, analysing the activities as separated events does not really convey the whole picture. It is more significant that continuous contact with key actors for the development has influenced various steps of the planning process and generated important input to the masterplan for the area. This was the first time that the City of Turku has worked with such a process, and the local project group gained a lot of experience. Five out of the six activities described were part of this series. The exception was the Future Hackathon, which was about developing digital applications for the use of services.

Some of the collaborative activities in the Itäharju-Kupittaa project have reached the level of co-governing - in other words, during that specific activity, important steps in the masterplan were elaborated and agreed upon. These activities were not only about allowing participants to express their preferences and gathering input that would inform later decisions by the project group, but about collectively identifying and agreeing on the main themes for development and action plans. Although no formal decisions about the masterplan were made during the activities, the results of the activities feed into the work with the masterplan at the city-planning department. For this reason, the level of influence remains advisory. Participants are consulted, but formal decisionmaking responsibility still lies with the public authority.
In this process of developing the masterplan, professional stakeholders (landowners, leaseholders, the different knowledge institutions in the science park, and public departments) played prominent roles. In some instances, the professional stakeholders were brought together with the public. For example, two days of Turku Future Forum were open to the public, and the Hackathon offered opportunities for professional stakeholders and the public to work together. However, within the six activities, the balance between public, private and people was uneven and could be discussed further, particularly with regard to how representatives of the public could complement the private participation in the planning process. What about the inhabitants of Turku in general what do they see as the city's needs and possibilities, including for this area in particular?

\subsection{Mūkusalas, Riga, Latvia}

Within Baltic Urban Lab, Riga city department started a planning process for the redevelopment of the Mūkusalas pilot site. Several activities have been initiated in the area, and different methods have been employed to include users, inhabitants and landowners. The greatest focus has been on the student competition - a six-month process involving students from three universities. This has been a totally new approach to the early planning of an area. One challenging parameter has been the fragmented land ownership. The local project group have brought together the public sector, private actors and representatives of the people for a range of activities. 


\section{Clean up days, April 2016 and 2017}

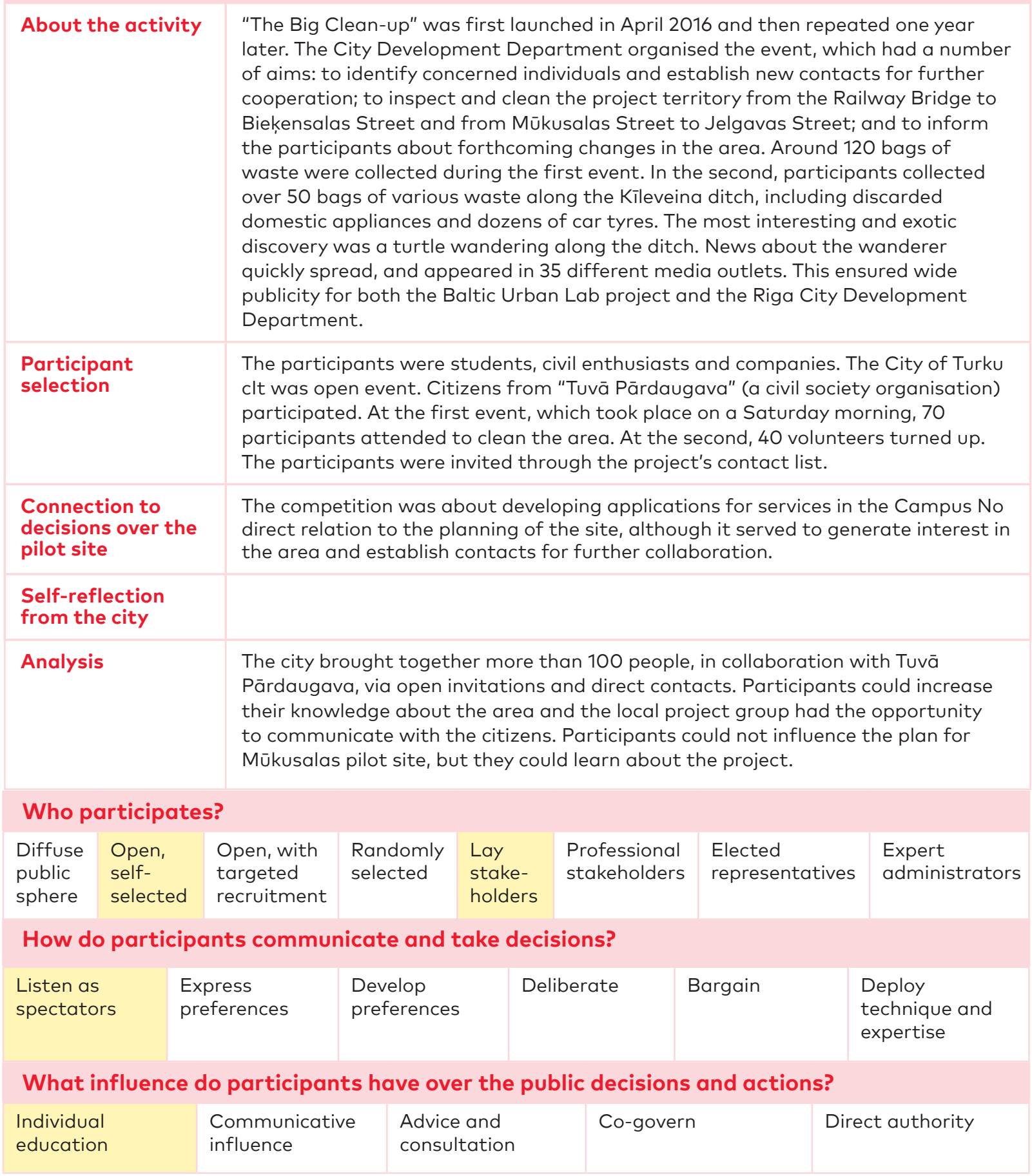




\section{Café Annas Därzs, September 2016}

\begin{tabular}{|c|c|}
\hline About the activity & $\begin{array}{l}\text { The meeting had three purposes: to inform participants about activities planned } \\
\text { within the development area; to provide information about the project activities; } \\
\text { and to organise stakeholder working groups for further dialogue. A workshop was } \\
\text { held with two working groups: "Problem-solvers" and "Dreamers". The former } \\
\text { identified problems and discussed solutions to these. The latter were asked to } \\
\text { propose their ideal development within the pilot site. Both groups put forward } \\
\text { several ideas about public- and private-sector involvement, transport, industry } \\
\text { and services. The local project group received ideas for future development and a } \\
\text { list of problems that the local people and entrepreneurs identified when passing } \\
\text { through the area. The event was also used to initiate contact with stakeholders, } \\
\text { with a view to ongoing relationships. The result of the workshop fed in to the local } \\
\text { project group's process of elaborating a development strategy for the pilot site. }\end{array}$ \\
\hline $\begin{array}{l}\text { Participant } \\
\text { selection }\end{array}$ & $\begin{array}{l}\text { The participants were stakeholders with a direct interest in the pilot site, e.g. } \\
\text { residents, landowners and entrepreneurs operating in the area, as well as students } \\
\text { and representatives of institutions from nearby areas. Social media (Facebook } \\
\text { and Twitter) was used to send invitations. Personal invitations were also sent by } \\
\text { e-mail to stakeholders encountered in previous meetings of the local project group. }\end{array}$ \\
\hline $\begin{array}{l}\text { Connection to } \\
\text { decisions over the } \\
\text { pilot site }\end{array}$ & Creating input to the development strategy. \\
\hline $\begin{array}{l}\text { Self-reflection } \\
\text { from the city }\end{array}$ & $\begin{array}{l}\text { Local stakeholders got a meeting place to improve their relationships } \\
\text { One of the biggest challenges was attracting stakeholders to participate in the } \\
\text { event, which was ultimately successful } \\
\text { Strong connections between local actors facilitate local territorial development. } \\
\text { Following this successful event, the local project group established guidelines for } \\
\text { future meetings: } \\
\text { - Make sure meetings have interesting and creative programmes } \\
\text { - Inform stakeholders personally and individually } \\
\text { - Remember the power of social networks, these are a good channel to } \\
\text { stakeholders }\end{array}$ \\
\hline
\end{tabular}

Analysis

Recruitment took the form of open social media invitations to the public, as well as targeted invitations to students and professional stakeholders. Participants developed ideas that the City of Riga collected and used to inform the development strategy - in other words, the influence was advisory. .

\begin{tabular}{|c|c|c|c|c|c|c|c|}
\hline $\begin{array}{l}\text { Diffuse } \\
\text { public } \\
\text { sphere }\end{array}$ & $\begin{array}{l}\text { Open, } \\
\text { self- } \\
\text { selected }\end{array}$ & $\begin{array}{l}\text { Open, with } \\
\text { targeted } \\
\text { recruitment }\end{array}$ & $\begin{array}{l}\text { Randomly } \\
\text { selected }\end{array}$ & $\begin{array}{l}\text { Lay } \\
\text { stake- } \\
\text { holders }\end{array}$ & $\begin{array}{l}\text { Professional } \\
\text { stakeholders }\end{array}$ & $\begin{array}{l}\text { Elected } \\
\text { representatives }\end{array}$ & $\begin{array}{l}\text { Expert } \\
\text { administrators }\end{array}$ \\
\hline
\end{tabular}

How do participants communicate and take decisions?

\begin{tabular}{|c|c|c|c|c|c|}
\hline $\begin{array}{l}\text { Listen as } \\
\text { spectators }\end{array}$ & $\begin{array}{l}\text { Express } \\
\text { preferences }\end{array}$ & $\begin{array}{l}\text { Develop } \\
\text { preferences }\end{array}$ & Deliberate & Bargain & $\begin{array}{l}\text { Deploy } \\
\text { technique and } \\
\text { expertise }\end{array}$ \\
\hline
\end{tabular}

What influence do participants have over the public decisions and actions?

\begin{tabular}{|c|c|c|c|c|}
\hline $\begin{array}{l}\text { Individual } \\
\text { education }\end{array}$ & $\begin{array}{l}\text { Communicative } \\
\text { influence }\end{array}$ & $\begin{array}{l}\text { Advice and } \\
\text { consultation }\end{array}$ & Co-govern & Direct authority \\
\hline
\end{tabular}




\section{Stakeholder meeting, July 2017}

\begin{tabular}{|l|l} 
About the activity & $\begin{array}{l}\text { The aim of the meeting was to discuss the concept of the Mūkusalas development } \\
\text { in less formal atmosphere, and to specify project targets and next steps for } \\
\text { the process. Unlike the "ordinary meetings", which tend to be comfortable for } \\
\text { professionals but less so for citizens, the event was moderated by a theatre actor } \\
\text { who helped participants to look at the territory in a creative way. At the meeting, } \\
\text { participants put forward ideas about how to develop the pilot site, and discussed } \\
\text { how Mūkusalas could be pictured in contrast to the rest of Riga. }\end{array}$
\end{tabular}

Participant selection
More than 30 people participated in this activity, including specialists from various city departments (strategic planning, urban and traffic planning, investment attraction, geospatial information, project planning and management specialists). Two local residents also participated. Professional stakeholders with businesses in the area were invited by email, based on the contact list established by the local project group..

The aim of the event was to give stakeholders a better understanding of the area and how it could develop, and to help define future work

Connection to pilot site

\section{Self-reflection \\ from the city}

A meeting involving both professional stakeholders and citizens was a new experience

The event improved relations between the different stakeholders

- It is challenging to keep the interest of participants and stakeholders through the projects and at each meeting

- It is important to show progress so that the participants can see the importance of their participation in meetings and activities

- Challenges included how to deal with opposing arguments from local inhabitants and entrepreneurs operating in the area, and how to arrive at compromises and solutions that were acceptable to all parties

Analysis $\quad \begin{aligned} & \text { The invitations were directed towards professional stakeholders and expert } \\ & \text { administrators, although two members of the public also participated. The } \\ & \text { method enabled participants to express and possibly refine their opinions } \\ & \text { and ideas concerning how Mūkusalas could develop. The method enabled the } \\ & \text { participant to act in advisory capacity, although the inclusion of defining project } \\ & \text { targets and important further steps brings the level of influence closer to co- } \\ & \text { governance. }\end{aligned}$

\section{Who participates?}

\begin{tabular}{|c|c|c|c|c|c|}
\hline $\begin{array}{l}\text { ffuse } \\
\text { jblic } \\
\text { here }\end{array}$ & $\begin{array}{l}\text { Open, } \\
\text { self- } \\
\text { selected }\end{array}$ & $\begin{array}{l}\text { Open, with } \\
\text { targeted } \\
\text { recruitment }\end{array}$ & & $\begin{array}{l}\text { Lay } \\
\text { stake- } \\
\text { holders }\end{array}$ & \\
\hline
\end{tabular}

\section{Elected representatives}

Expert administrators

How do participants communicate and take decisions?

\begin{tabular}{|c|c|c|c|c|c|}
\hline $\begin{array}{l}\text { Listen as } \\
\text { spectators }\end{array}$ & $\begin{array}{l}\text { Express } \\
\text { preferences }\end{array}$ & $\begin{array}{l}\text { Develop } \\
\text { preferences }\end{array}$ & Deliberate & Bargain & $\begin{array}{l}\text { Deploy } \\
\text { technique and } \\
\text { expertise }\end{array}$ \\
\hline
\end{tabular}

What influence do participants have over the public decisions and actions?

\begin{tabular}{|c|c|c|c|c|}
\hline $\begin{array}{l}\text { Individual } \\
\text { education }\end{array}$ & $\begin{array}{l}\text { Communicative } \\
\text { influence }\end{array}$ & $\begin{array}{l}\text { Advice and } \\
\text { consultation }\end{array}$ & Co-govern & Direct authority \\
\hline
\end{tabular}




\section{Mūkusalas workshop 2050, December 2017}

\begin{tabular}{l|l}
\hline About the activity & The workshop took place in Mūkusalas and aimed to clarify and understand the \\
views of local residents, business people and all other stakeholders regarding \\
the vision of the development of the territory. The event was part of the \\
student competition, in which students drew up proposals for the development \\
of Mūkusalas, and gave students insight into the participants' views on the \\
development. The student competition later became a larger-scale competition, in \\
which students were invited to draw up development plans for the pilot site (see \\
next event). The workshop included presentations, time for questions, discussions \\
and work in small groups. Students organised meetings with stakeholders to \\
discuss project ideas. There were three roundtable discussions with presentations \\
visualised on maps.
\end{tabular}

The meeting resulted in a number of maps annotated with ideas that students could use in their proposals. The event was organised on behalf of the Riga City Development Department by SIA "Arcconsult", along with students from University of Latvia (LU), Riga Technical University (RTU), and Riga International School of Economics and Business Administration (RISEBA).

\begin{tabular}{l|l}
$\begin{array}{l}\text { Participant } \\
\text { selection }\end{array}$ & $\begin{array}{l}\text { The students were recruited from three universities. The stakeholders were } \\
\text { identified from previous events, and consisted of both residents and professional } \\
\text { stakeholders. }\end{array}$ \\
$\begin{array}{l}\text { Connection to } \\
\text { decisions over the } \\
\text { pilot site }\end{array}$ & $\begin{array}{l}\text { Students received local actors' views on Mūkusalas, which they then used when } \\
\text { developing their proposals for the pilot site. }\end{array}$ \\
\hline $\begin{array}{l}\text { Self-reflection } \\
\text { from the city }\end{array}$ & $\begin{array}{l}\text { Students thought that the meeting was useful, because in their view the right } \\
\text { people participated and the discussion was straightforward } \\
\text { Students communicated well with the other participants } \\
\text { One challenge was how to handle ideas that were less realistic. }\end{array}$
\end{tabular}

Analysis

Students are recruited due to their specific role and competencies. Professional stakeholders and residents from earlier events were involved. The latter can be considered recruited through open self-selection, since this was an open and voluntary event. Participants were asked to express their views, which increased the students' knowledge.

\section{Who participates?}

\begin{tabular}{ll|l|l|l|l|l|l}
$\begin{array}{l}\text { Diffuse } \\
\text { public } \\
\text { sphere }\end{array}$ & $\begin{array}{l}\text { Open, } \\
\text { self- }\end{array}$ & $\begin{array}{l}\text { Open, with } \\
\text { selected }\end{array}$ & $\begin{array}{l}\text { Randomly } \\
\text { targeted } \\
\text { recruitment }\end{array}$ & $\begin{array}{l}\text { Lay } \\
\text { selected }\end{array}$ & $\begin{array}{l}\text { Professional } \\
\text { stake- } \\
\text { holders }\end{array}$ & $\begin{array}{l}\text { Elected } \\
\text { stakeholders }\end{array}$ & $\begin{array}{l}\text { Expert } \\
\text { representatives }\end{array}$ \\
administrators
\end{tabular}

How do participants communicate and take decisions?

\begin{tabular}{|c|c|c|c|c|c|}
\hline $\begin{array}{l}\text { Listen as } \\
\text { spectators }\end{array}$ & $\begin{array}{l}\text { Express } \\
\text { preferences }\end{array}$ & $\begin{array}{l}\text { Develop } \\
\text { preferences }\end{array}$ & Deliberate & Bargain & $\begin{array}{l}\text { Deploy } \\
\text { technique and } \\
\text { expertise }\end{array}$ \\
\hline
\end{tabular}

What influence do participants have over the public decisions and actions?

\begin{tabular}{|c|c|c|c|c|}
\hline $\begin{array}{l}\text { Individual } \\
\text { education }\end{array}$ & $\begin{array}{l}\text { Communicative } \\
\text { influence }\end{array}$ & $\begin{array}{l}\text { Advice and } \\
\text { consultation }\end{array}$ & Co-govern & Direct authority \\
\hline
\end{tabular}




\section{Student competition, September 2017-February 2018}

About the activity The student competition was organised for the first time in Riga and continued for six months. The purpose of the competition was to get the best proposal for the development of the pilot site and to test a new planning method. Student teams came from the University of Latvia (LU), Riga Technical University (RTU) and Riga International School of Economics and Business Administration (RISEBA), and from the disciplines architecture, spatial planning, transport engineering, landscape architecture, geography, environmental science, sociology, culture, economy and communication.

On 9 February at National Library of Latvia, students presented the proposals for the redevelopment of the Múkusalas area. A professional jury evaluated the competition proposals, and the public were invited to express their opinions. The jury consisted of representatives of Riga City Council City Development Department and Riga City Traffic Department, Riga City Architect's Office, as well as users of the Mūkusalas area and several professional architects and landscape specialists.

\begin{tabular}{l|l} 
Participant & The participants were students and lecturers from three different universities,
\end{tabular} selection as well as different stakeholders, pilot site users and landowners, residents and NGOs.

\section{Connection to decisions over the pilot site}

\section{Self-reflection} from the city
The students' proposals were directly linked to the redevelopment of the pilot site.

The local project group is satisfied with the process and the results. The project generated three perspectives and innovative proposals for Mūkusalas pilot site, and represented a successful test of a new method.

- All three groups highlighted the development potential for Mūkusalas, while also characterising the area as a multifunctional urban environment that could be well-suited to residents and has great potential for developers.

- The competition is a great method for developing innovative and creative proposals.

- It is important to strike the appropriate balance between professionalism and the students' capacities. The jury need to be aware that students are not professionals

- It was difficult to decide on the best proposal. Residents had different opinions about the proposals chosen by the professionals, but following discussion, all sides came to an agreement.

- During a process like this, a competitive atmosphere between different universities can affect the working environment

Greater involvement by certain stakeholders, e.g. landowners, would have been beneficial, but this proved difficult because they were either too busy or not interested.

Analysis

The participants were recruited both through a targeted recruitment and invited as professional stakeholders. Within a specified timeframe, the students could develop their ideas for the future of Múkusalas. They could also make use of the expertise they had gathered so far, and each team probably had discussions characterised by compromise and/or deliberation. A jury evaluated the proposals, but formal authority lay with decision-makers from the city. As such, the influence must be seen as advisory. However, since the winning proposal has an important role in the planning of Mükusalas, it means the students in the winning team contributed to the development of a strategy, which makes it a form of cogovernance. 


\begin{tabular}{|c|c|c|c|c|c|c|c|c|}
\hline \multicolumn{9}{|c|}{ Who participates? } \\
\hline $\begin{array}{l}\text { Diffuse } \\
\text { public } \\
\text { sphere }\end{array}$ & \multicolumn{2}{|c|}{$\begin{array}{l}\text { Open, } \\
\text { self- } \\
\text { selected }\end{array}$} & $\begin{array}{l}\text { Open, with } \\
\text { targeted } \\
\text { recruitment }\end{array}$ & $\begin{array}{l}\text { Randomly } \\
\text { selected }\end{array}$ & $\begin{array}{l}\text { Lay } \\
\text { stake- } \\
\text { holders }\end{array}$ & $\begin{array}{l}\text { Professional } \\
\text { stakeholders }\end{array}$ & $\begin{array}{l}\text { Elected } \\
\text { representatives }\end{array}$ & $\begin{array}{l}\text { Expert } \\
\text { administrators }\end{array}$ \\
\hline \multicolumn{9}{|c|}{ How do participants communicate and take decisions? } \\
\hline \multicolumn{2}{|c|}{$\begin{array}{l}\text { Listen as } \\
\text { spectators }\end{array}$} & \multicolumn{2}{|c|}{$\begin{array}{l}\text { Express } \\
\text { preferences }\end{array}$} & \multicolumn{2}{|l|}{$\begin{array}{l}\text { Develop } \\
\text { preferences }\end{array}$} & Deliberate & Bargain & $\begin{array}{l}\text { Deploy } \\
\text { technique and } \\
\text { expertise }\end{array}$ \\
\hline \multicolumn{9}{|c|}{ What influence do participants have over the public decisions and actions? } \\
\hline \multicolumn{3}{|c|}{$\begin{array}{l}\text { Individual } \\
\text { education }\end{array}$} & $\begin{array}{l}\text { Communicative } \\
\text { influence }\end{array}$ & \multicolumn{2}{|c|}{$\begin{array}{l}\text { Advice and } \\
\text { consultation }\end{array}$} & Co-govern & & Direct authority \\
\hline
\end{tabular}

\section{Summary}

Most of the activities in this process were advisory to the formal decision-making process. However, many of the activities have influenced the decisionmakers with visions about the site. Collectively, the series of events will influence the future of Mūkusalas. This is specifically the case for the result of the student competition.

Most of the activities were directed towards the private sector, and invitations were sent to professional stakeholders. Many participants were invited and encouraged to participate through targeted recruitment. For two of the activities, a more open invitation was used in order to attract a broader group of people. Non-professionals were involved in the clean-up days, but this did not influence decisions connected to the pilot site. Instead, citizens carried out work in the area and in this way acquired information about the redevelopment project. Obviously, students from various disciplines have had a great role. The local project group have continuously gathered contact information during the planning process, which has served to expand its network of contacts.

The participation in meetings has mostly involved developing or expressing preferences. The focus was on group discussions in which participants gain an increased understanding about the pilot site. The clean-up day was the only activity in which participants merely received information about the future development (i.e. they were invited to "listen as spectators", in Fung's terminology), even though they also learned more about the area itself. During the student competition and in the separate student groups, it can be assumed that many types of communication took place. 


\section{Reflections and key messages}

In all four brownfield planning projects that have formed part of Baltic Urban Lab, the local project groups have tried out new methods of interaction, mainly with private actors and citizens. The projects for Mūkusalas in Riga and Skoone Bastion area in Tallinn have involved a wide spectrum of stakeholders. In Skoone Bastion area, the focus has been on including citizens to a greater extent than is usual in the planning processes in Estonia, mainly through new digital means. In the Mūkusalas project, there has been an expanded focus on collaborating with universities and including students in drawing up a vision. The Inner Harbour project in Norrköping has had a particular focus on the communication of complex aspects of the planning project, and on using new means of communication to make these aspects accessible to the public. It has also been engaged in an expanded process with real estate developers to ensure high levels of quality in the restructuring and building of the area. In the Itäharju-Kupittaa project, the emphasis has been on key actors with economic interests in the area, and on working with them to set up a process that can generate input into the masterplan. However, there have also been several open public events. Both in Mūkusalas and in Itäharju-Kupittaa, the projects have used competitions to gather ideas for the land-use plans.

Some of the cities have had similar focuses in terms of the key participants in the stakeholder activities, and the kind of methods employed. All of the cities have learned a lot along the way. In this chapter, we summarise the lessons learned, and provide recommendations based on our reflections. These can be useful for others utilising the 4P approach in the planning of brownfield areas. We also present the patterns we have observed in the types of issues that participants are invited to express opinions on. In doing so, we reflect on the different dynamics in the planning processes in relation to the three different types of actors in the 4P concept - public, private and people.

Before turning to our reflections and recommendations, it is important to emphasise that all of the cities have worked hard with a large number of stakeholders to realise their projects in a collaborative manner. This is an inherently challenging and a constantly evolving process. The sharing of lessons learned is an important way to help develop more knowledge and improve future planning that takes into account the interests of the public, the private and the people.

\subsection{Methods used in Inner Harbour, Skoone Bastion area, Mūkusalas and Itåharju-Kupittaa}

All of the pilot sites in Baltic Urban Lab are brownfield areas, which entails specific challenges in terms of planning and development, e.g. heavy contamination, inaccessible areas for pedestrians due to railways or poor public transport supply, heavy industrial activities and a large number of stakeholders and landowners who are impacted by the project (this is particularly the case for Mūkusalas in Riga). Some of these challenges are reflected in the type of stakeholder engagement activities that the cities have been testing. For example, establishing a good collaboration with private actors, e.g. landowners and real-estate developers, is at the core of several of the tested methods. This is the case for all of the cities concerned. Norrköping set up an intense collaboration and Turku ran a series of workshops with private stakeholders in order to involve them in the drafting of the masterplan.

Another example is the Earth Autopsy initiated by the local stakeholder group in Norrköping due to heavy contamination in the Inner Harbour. This particular situation has been of major concern for residents of Norrköping, and was therefore a key focus area in the development of new tools for communicating and interacting with stakeholders and residents. Another example from the same city is the risk-evaluation workshop that preceded the decision on which method for soil remediation would be chosen. The question of inaccessibility is reflected in the case of Skoone Bastion area, where a two-kilometre cycle and pedestrian path was set up as a temporary solution to ease access to the pilot site during the planning phase. 


\section{Digital tools for participation}

The project in the Skoone Bastion area has involved developing and working with two new digital tools, the purpose of which is to gather input on the planning. Due to their high functionality in generating input from local residents, both the AvaLinn app and the web-based GIS map will be used in future planning projects. The local project group acquired a lot of knowledge along the way, particularly that user-friendliness is of the utmost importance. The AvaLinn app was designed so that users can see the future plans, read information about changes to the urban space, share opinions and "like" or "dislike" suggestions from the city. The local project group found that it was sometimes unclear exactly what users had "liked", which made it difficult to analyse the input. Further, this participation tool addresses a small subsection of citizens - namely app users, who tend to be younger people.

Within the Inner Harbour project, "Earth Autopsy" has been developed as a tool to communicate complex planning issues - in this case underground contamination - to the audience. This has proved to be of great interest to users, although the tool itself still has some limitations in terms of the information it can show. For the local project group, this is a learning process, and they intend to develop the functions further. As such, Earth Autopsy is not actually a tool for participation, but for one-way communication (unlike AvaLinn, in which users can post comments and communicate their opinion about the suggested plan). However, if used in participatory activities, it serves to increase participants' understanding of the challenges of contamination, and can in this way help to generate more insightful input from participants. As long as it is used in a public meeting place with a high number of visitors, it supports learning among the public and contributes to general discussions on planning issues.

One advantage with digital tools that have a broad reach in terms of communicating with people and disseminating information. A downside is that if direct interaction between the planners and the participants doesn't occur, it can be difficult for planners to know whether users understand the information correctly, and therefore whether users are providing input on the basis of a correct understanding.

\section{Tips and recommendations:}

- Conscious and ambitious outreach is needed to recruit enough participants and the "right" ones - to activities or websurveys that are intended to develop digital tools for participation

- Don't underestimate the importance of clear and easy-to-understand language when communicating planning issues, including through maps and planning instruments, to non-professionals

- Make sure questions to the public are clear so that the answers can be easily understood

- Providing information about the digital tool by placing signs in situ is an effective way of gaining users

- When testing the tool, remember to assess whether the test-users have understood questions correctly

- If using external guides to introduce users to the tools, it is advantageous if they are knowledgeable about urban planning - Users prioritise speed, interactivity and functionality in digital tools

- Be aware that digital tools can make people ask follow-up questions that the tools cannot answer.

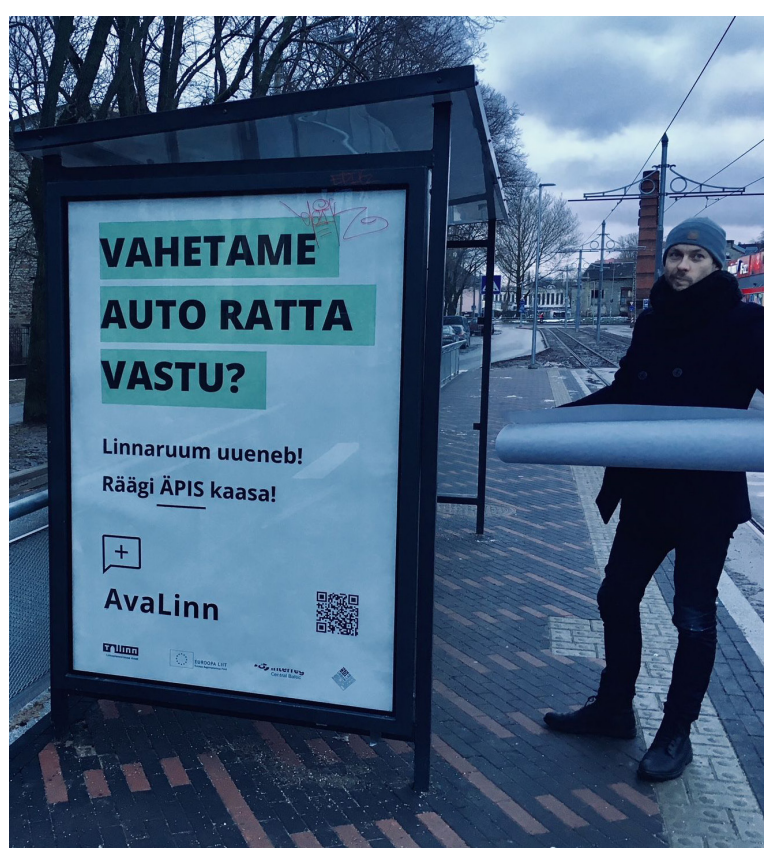

Photo 2. Information about AvaLinn app close to the pilot site. Source: Tallinn Urban Planning Department. 


\section{Close collaboration with students}

The main aim of the three-day student workshop about Skoone Bastion was to contribute to the development of a vision for the whole area. The project group found that it was easier to engage participants in this way than via activities focused on the development of technical tools - even though the workshop required that participants give up significant amounts of time. However, if well arranged, students can use their study hours, which makes it easier for students to be involved than other citizens. The local project group experienced that the interactive character of the activity and the urgency of the topic provided a good basis for stakeholders to interact, which is positive for the project continuing into the future. Compared to the collaborative process of the vision competition in Mūkusalas, here the students worked rather independently, albeit with an in-depth introduction from the planners. The students' work has informed the planning process by inspiring it.

For the process with students in Mūkusalas in Riga, the local project group chose another approach, in which students played a prominent role in developing the vision through a competition. The student competition was an important activity for Riga in Baltic Urban Lab, and attracted a lot of participants and attention. The local authority will realise the winning proposal, although it needs to work with the action plan and implementation strategy. This means that the winning proposal has a great impact on the future design of Mükusalas. The local project group dedicated many hours to devising a well-functioning process, including providing guidance and education for students. The collaborative process, involving various different universities and competence areas, has probably been beneficial for both the academic institutions and the students. One important finding is that students tend to work very hard and sometimes put in too much effort. The local project group will take this into account when arranging collaborations with students in the future. The local authority has signed a cooperation memorandum with University of Latvija, which outlines a plan for future collaboration with students.

These competitions show how students can contribute "fresh thinking", but for the same reason, their work can also be unrealistic and impossible to realise or incompatible with other council strategies. Including students is also a way to open up the planning process to inhabitants that wouldn't otherwise be able to access this process, and to include more perspectives on the development of the area.

\section{Tips and recommendations:}

- Students can be a great source of innovative ideas

- Participants show a high degree of engagement

- Students need good mentoring

- Students tend to dedicate many hours of work on their proposals, and it is necessary to ensure that they are not exploited and that the working environment is good - There is a need to handle social conflicts that can emerge when students become competitors in relation to each other

- Be aware that students' proposals will need further elaboration.

\section{Close collaboration with professional stakeholders}

In both the Itäharju-Kupittaa and Inner Harbour projects, special efforts have been made with regard to key stakeholders. In the first case, this is seen in the series of workshops that provide input into the masterplan; in the second, through continuous dialogue on how to implement the existing vision. The key stakeholders here are landowners, land-renters, companies with ongoing activities at the site and real-estate developers. In the case of Itäharju-Kupittaa, universities have also been crucial, since they perform so many of the activities in the area.

In the case of Mūkusalas, there have also been a couple of meetings with key stakeholders, for the purpose of initiating dialogue and collaborations for the planning of the area. Tallinn began their planning process with a series of meetings to gain precisely this sort of input. However, both in Riga and in Turku, the local project groups have experienced challenges when it comes to recruiting stakeholders and motivating them to participate. Finding common ground is crucial for ensuring a fruitful future collaboration. The cities report that this is a time-consuming process, although it is of major importance, since potential investors and developers are the key to funding the redevelopment process and making it happen. 
How can you make the collaborative forums as effective as possible, while at the same time balancing time and cost?

\section{Tips and recommendations:}

- Approach key stakeholders individually, personally and in good time before the activity, to increase the chance they will participate

- Make use of existing professional and social networks for invitations and making contacts

- Be clear about the purpose of meetings and the expected roles of participants

- If there are series of meetings, at each one show the progress that has been made since last time

- Finding common goals and interests takes time

- Creating an informal setting can make meetings more creative

- Make use of various workshop methods to extract as much as possible from these meetings

- External moderators can be useful

- Be transparent - ensure that you know how to make use of the results of these processes

- Be flexible - these forums can generate new ideas on how to collaborate.

\section{Social media}

What kind of dialogue is enabled through social media accounts? Yes, questions can be posed and answered, but are rarely followed up as in a faceto-face dialogue. The limitations of this type of communication should be acknowledged. It is easy to become infatuated by the very high numbers of people that can be reached through social media, but information should not be confused with dialogue or participation. Social media is mainly a channel for communication, and for individuals to acquire information. It can be used to express opinions, but can it also be a means of influencing the project? It is certainly useful for reaching out to women and younger people. Some research suggests that people who are politically active on social media are also politically active in other ways, thereby reinforcing the uneven distribution of political influence. On the contrary, other research reveals that people who are less politically active in traditional forums actually do use digital means for political engagement (SOU 2016:5). However, there are critical perspectives on online activism, namely that it is very easy to express support for different views, which means those views can be superficial and not deeply thought through - and the act of "liking" and "sharing" on social media is derided as "clicktivism". In addition, people tend to be affected by peer group pressure in the social media sphere. Another criticism of "clicktivism" is that it is a low form of engagement that doesn't necessarily result in any practical action, and that the potential impact on policy is low. On a hierarchical scale of "digital activism", some researchers rank "clicktivism" the lowest, and "hacktivism" the highest, reflecting the differing impact that an activity has on a cause or organisation (George, J. and Leidner, D. 2018).

As a way of reaching out with information, social media proved effective for, e.g. the Future Hackathon in Turku, where most participants received information via social media. However, in this case, social media was used for recruitment to an activity in a specific time and space, whereas the gathering of ideas for the pilot site took place during the activity itself. The difference between reaching out with information, which is the basis of any kind of action involving the public, and including citizens in participatory activities, should not be forgotten.

\section{Tips and recommendations:}

- Social media is a complementary channel for reaching out with information

- Social media can be an effective way of recruiting people to participatory activities

- Try to define the specific quality of discussions in the social media sphere

- Responding to all comments that are submitted from the public requires resources - make sure you can meet this commitment

- Create a system for responding to questions and comments

- Ask yourself if information and opportunities to express "likes" or post comments should be seen as participation or communication. 


\section{Promoting public activity in urban areas}

The development of urban garden plots in the Skoone Bastion area and the clean-up days in Mūkusalas exemplify a type of makeshift or even impromptu opportunity for people to either better utilise land in cities for recreation purposes or contribute to the improvement of the urban environment. This goes hand in hand with the concept of tactical urbanism (Lydon, M. et al. 2012), which describes how incremental and community-led smallscale efforts improve how urban areas can be used as a way to stage and develop the momentum for larger improvements and investments. According to Lydon et al (2012), tactical urbanism allows local actors to experiment with new concepts before making larger financial or political commitments. In this way, it can be seen as a form of do-it-yourself urbanism, which can be supported by public authorities (or not) and can inspire new ideas for improving urban living. In the Skoone Bastion area, the project learned that even though the initiative was halted due to national policy on world heritage sites, there were positive outcomes at city level, as it brought to prominence the discussion about urban gardening and how public authorities can collaborate with local initiatives.

Lydon, M. et al. (2012) presents five characteristics of successful tactical approaches:

1. A phased approach to instigating change

2. An offering of local ideas for local planning challenges

3. Low risks with the possibility of a high reward

4. The development of social capital between citizens, and the building of organisational capacity between public-private institutions, non-profit/ NGOs, and their constituents.

In addition to these characteristics, the experiences of Baltic Urban Lab have informed the following recommendations when considering these types of bottom-up urban improvement approaches:

\section{Tips and recommendations:}

- Ensure that to every extent possible, the ownership/management/coordination of the activity is in the hands of the community members, whether this is a formal group or a more random selection of the general public.

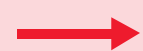

Develop a small fund for supporting tactical urbanism ideas at local-government level, especially in the early stages of a programme, and for supporting such activities in general.

- Especially in the initial stages, allow ideas and initiatives to develop organically and learn from them. The default position is to say no, because the council may not yet have guidelines or regulations that permit the activity to take place.

- Once the initial activities have taken place, and have hopefully been successful, consider developing guidelines and clear routines, potentially including an online platform, that provide clear information about how community members can organise community-development activities. This will highlight the local authority's support for these events.

- Provide a digital story of events that highlight good practices and ideas, which can serve as inspiration for other community members.

- Support the use of social media for communicating these activities, including the promotion of the local council's social media pages.

\subsection{Public, private and people - different dynamics in the planning process}

\section{Influencing either planning, temporary uses or tools for participation}

Most of the activities discussed have been connected to the development of a specific pilot

site. Some of the partner cities have also invited both representatives from the private sector and citizens to give input or be part of developing tools for participation. This is an aspect of participation that is not frequently highlighted as an example of participation, although it increases the chance that the tools will be useful and accessible to the users. The hackathon in Turku was about developing a kind of participation tool, although the applications that competitors developed during the event are supposed to be used by people working and living in the area in the future. As such, it was not a tool for influencing the planning project per se. A few activities have promoted 
public activity in the pilot site, resulting in raising awareness about or making use of the pilot site. The former applies to the two clean-up days in Mūkusalas, Riga; while the second applies to the temporary gardening and the pedestrian path in the Skoone Bastion area, Tallinn. The boat trips during the public hearing in the Inner Harbour were a way of increasing people's knowledge of the pilot site by engaging them in an activity there.

\section{Public-private relations}

In general, we see that deeper and more advanced forms of communication take place when the participants are targeted - and even more so when they are professionals. However, there are two exceptions to this. The first is the threeday workshop with students and others in Tallinn, which had elements of self-selected recruitment. The deliberative features in these activities occur when the participants get the opportunity to develop a deeper understanding of an issue or to work on solutions together and, finally, agree on a way forward. However, there is one important element that does not correspond to the deliberative process. Mansbridge et al. (2010) proclaim that deliberation occurs when different perspectives (rather than, e.g. different "social groups") ${ }^{14}$ are represented among the participants. However, we have not seen any instance in which participants have been recruited along these lines. The second exception is the student competition in Mūkusalas, where the winning proposal will inform the planning of the area. This means that students contributed to drafting a strategy that will be implemented, making them part of a co-governing process.

Would cities gain more perspectives on the planning issues if they worked to ensure that all perspectives were represented?

\section{Tips and recommendations:}

- The setting up of a deliberative process should be preceded by compiling an inventory of existing perspectives on the issue. This inventory should impact on the recruitment in such a way that the different perspectives are present.

14 Different social groups could include children, young people, parents of young children, homeless people, politically disenfranchised individuals, etc.
Some of the cities have worked closely with private-sector stakeholders that have economic impact over the projects. The highly refined and innovative processes of working with real-estate developers in the Inner Harbour project, and landowners and lease-holders in Itäharju-Kupittaa, come close to co-governance, in the terminology of Fung (2006) - the participants in these processes work together to develop strategies and visions, or at least seem to have a great impact on them. The processes in themselves allow for close collaboration, which makes the planning process effective in some ways, costly in others. However, once the participants agree on a way forward, there is a far greater chance that visions and strategies are actually implemented. However, critical questions could be asked about whether, in such cases, the 4P approaches work sufficiently with the people dimension to balance the influence of the private actors. Another question is whether these processes are sufficiently transparent, since they are so important to the future development.

\section{Public-public relations}

Some of the pilot projects have experienced challenges in terms of internal organisation when working in a new way, in a more open process, and when preparing plans and visions that are outside of the formal planning system. Difficulties have arisen due to the differing stances of other council departments. When this has become clear, it has also been evident that a stronger presence from local politicians would have helped to support the project. Two conclusions can be drawn from this - first, that collaboration between the city's different departments needs a stronger focus; and second, that deeper links with the political board should be established and formalised. Another important lesson is related to the importance of agreeing on responsibilities and procedures at an early stage - although, naturally, this is difficult when introducing completely new working methods. In the case of the Skoone Bastion area, a lot of effort has gone into strengthening the collaboration between the city planning department and the traffic department, since the traffic situation is one of the main issues in relation to managing the development of the area. 


\section{Tips and recommendations:}

- Count for extra time when preparing planning projects that are not based on legislation

- A project that has clear support from local politicians has a much stronger mandate when the time comes to take action.

- The links between the project and the political board should be established and formalised by the start

- Collaboration between the city's different departments needs a strong focus already from the beginning

\section{Public-people relations}

Tallinn has actively co-operated with NGOs right from the start and involves them in both smaller meetings and larger open events. They also co-operate with NGOs in practical sense when it comes to, e.g. the temporary uses and engagement of local active citizens. The two processes with students are examples of reaching out to "people" who would not normally be considered professional actors within the planning process, although they will soon become that, depending on their area of interest.

Except from students, we have not seen any particular efforts to reach out to specific social groups within the people dimension. Often, the focus of conscious recruitment is on ensuring the representation of different social groups, with a particular focus on reaching out to those who are otherwise difficult to include. This could be extended to all cities where there is an aim of including those who are seldom part of political discussions, in order to ensure more equitable planning processes. In the Inner Harbour project, recruitment was carried out in shopping malls for this reason.

\section{Tips and recommendations:}

- Include in the stakeholder analysis a focus on the people-dimension, to identify those who might be more affected by the project, but less active in its development.

- And, or alternatively, collect the different views and perspectives existing among the public (not necessarily connected to social groups), to make sure that these opinions are represented and heard in some way during the planning process
Ultimately, the goal of the 4P approach in brownfield planning is to improve resilience and attractiveness during city building processes. This is achieved through delivering a transparent planning process that promotes engagement. It is based on the understanding that if people can contribute to the development of areas in which they will live and work, then the area has a higher chance of being a qualitative addition to the urban landscape. This is doubly important in brownfield areas, where existing land-users may have a high vested interest in the development, and in areas that have general historical or cultural importance in the urban context.

This report has touched on a number of ways in which different perspectives - public, private and people - are included in the planning process as participants. The examples range from student competitions and hackathons to digital platforms and tactical urbanism approaches, such as urban gardening or city clean-up. These approaches vary greatly - some make clear and explicit contributions to technical design processes, whereas others inform events or activities that enable people to gain experiences in new ways.

In conclusion, the messages and lessons above highlight the importance of considering the following four questions when aiming for a 4P-approach in planning of brownfield areas:

1. In what ways do the methods/activities contribute to increased transparency?

2. In what ways have the methods/activities enabled early influence from citizens?

3. In what ways have power imbalances between different kind of actors been addressed? 


\section{References}

Arnstein, R. S. (1969) A Ladder of Citizen

Participation. Journal of the American Institute of Planners 35:4, 216-224 DOI: 10.1080/01944366908977225

Fung, A. (2006) Varieties of participation in complex governance. Public Administration Review December 2006 Special Issue

Fung, A. (2015) Putting the public back into governance: The challenges of citizen participation and its future. Public Administration Review 2015 DOI: 10.1111/ puar.12361.

George, J. and Leidner, D. (2018) Digital Activism: a Hierarchy of Political Commitment. Proceedings of the 51st Hawaii International Conference on System Sciences 2018

Kosack, S. and Fung, A. (2014) Does transparency improve governance? The Annual Review of Political Science 2014:17 p. 65-87

Lydon, M., Bartman, D., Garcia, T., Preston, R., and Woudstra, R. (2012) Tactical Urbanism 2: Short-term Action Long-term Change. Street Plans, New Yourk. Available online: http:// issuu.com/streetplanscollaborative/docs/ tactical_urbanism_vol_2_final?mode=windo w\&backgroundColor=\%23222222. (Accessed: 2018-05-18).

Mansbridge, J., Bohman, J., Chambers, S., Estlund, D., Follesdal, A., Fung, A., Lafont,
C., Manin, B. and Martí, J. L. (2010). The Place of Self-Interest and the Role of Power in Deliberative Democracy. The Journal of Political Philosophy, 18(1) 64-100 doi: 10.1111/j.1467-9760.2009.00344.x

Perjo, L., Fredricsson, C., Oliveira e Costa, S. (2016) Public-Private-People partnership in urban planning Working paper (Deliverable 2.3.1 Potential and challenges of applying PublicPrivate-People partnership in urban planning Perjo, L., Fredricsson, C., and Oliveira e Costa, S. (2017) Planning Systems and Legislation for Brownfield Development in the Central Baltic Countries

SOU 2016:5 Låt fler forma framtiden! Betänkande av 2014 års Demokratiutredning - Delaktighet och jämlikt inflytande Statens offentliga utredningar Elanders Sverige $A B$, Stockholm 2016. ISBN 978-91-38-24401-2 ISSN 0375-250X

Tahvilzadeh. N. (2015) Deltagande styrning optimistiska och pessimistiska perspektiv på medborgardialoger som demokratipolitik in Lindholm, T., Oliveira e Costa, S., Wiberg, S. (2015) Medborgardialog - demokrati eller dekoration? Tolv röster om dialogens problem och potential i samhällsplaneringen Arkus skrift nr 72 Ljungbergs tryckeri, Klippan ISBN: 978-91-980422-3-8 



\section{(11) Nordregio}

P.O. Box 1658

SE-111 86 Stockholm, Sweden

nordregio@nordregio.se

www.nordregio.se

www.norden.org

ISBN 978-91-87295-60-7

ISSN: 1403-2503

DOI: doi.org/10.30689/R2018:1.1403-2503 